\author{
Universidade de São Paulo \\ Faculdade de Filosofia, Letras e Ciências Humanas \\ Departamento de Letras Modernas \\ Programa de Língua Espanhola e Literaturas Espanhola e
}

Hispano-americana

\title{
Intersecções entre as fotografias e a narrativa de Juan Rulfo
}




\author{
Universidade de São Paulo \\ Faculdade de Filosofia, Letras e Ciências Humanas \\ Departamento de Letras Modernas \\ Programa de Língua Espanhola e Literaturas Espanhola e
}

Hispano-americana

\title{
Intersecções entre as fotografias e a narrativa de Juan Rulfo
}

Adriana Bezerra da Silva

Dissertação apresentada ao Programa de Língua Espanhola e Literaturas Espanhola e Hispanoamericana do Departamento de Letras Modernas da Faculdade de Filosofia, Letras e Ciências Humanas da Universidade de São Paulo para obtenção do título de Mestre.

Orientadora: Prof ${ }^{\mathrm{a}}$. Dr ${ }^{\mathrm{a}}$. Adriana Kanzepolsky

De acordo

Prof $^{a}$. Dr ${ }^{a}$. Adriana Kanzepolsky

São Paulo

2015 
Adriana Bezerra da Silva

Intersecções entre as fotografias e a narrativa de Juan Rulfo

Dissertação apresentada ao Programa de Língua Espanhola e Literaturas Espanhola e Hispano-americana do Departamento de Letras Modernas da Faculdade de Filosofia, Letras e Ciências Humanas da Universidade de São Paulo para obtenção do título de Mestre.

Área de concentração: Literatura hispano-americana

Aprovada em:

\section{Banca Examinadora}

Prof $^{\mathrm{a}}$. Dr ${ }^{\mathrm{a}}$. Adriana Kanzepolsky (orientadora)

Instituição: FFLCH/USP Assinatura:

Prof. Dr.

Instituição:

Assinatura:

Prof. Dr.

Instituição:

Assintatura:

Prof. Dr.

Instituição: (suplente)

Prof. Dr

Assintatura:

Instituição: (suplente)

Assintatura: 
Dedicatória

Dedico esta dissertação ao meu pai por me ensinar a sabedoria do silêncio e ao meu irmão por me ensinar a abraçar.

Dedico-a à minha mãe por me ensinar a ler antes de ir à escola, por me contar histórias, por comprar minhas revistas de colorir, por me dar uma máquina de escrever de aniversário, quando as crianças pediam bicicleta. E, principalmente, por me ensinar que amor não tem dimensão. 


\section{Agradecimentos}

À professora doutora Adriana Kanzepolsky, orientadora e conselheira, pela colaboração, pelo tempo dedicado (recebendome em sua casa até nos fins de semana), pela grande inspiração e motivação.

Ao professor doutor Alberto Vital pela acolhida no México, pela atenção e colaboração para este trabalho.

Aos professores doutores Helouise Costa e Marcos Piason Natali, componentes da banda de qualificação pelos preciosos comentários.

Ao $\mathrm{CNPq}$ pelo financiamento fornecido para o desenvolvimento da presente pesquisa.

À Red Macrouniversidades América Latina y Carile pelo financiamento e oportunidade da realização de intercâmbio.

Aos amigos Fernando Ibarra e Hermann Carrasco por ser minha família na Cidade do México.

Aos amigos das Letras e da USP Agatha, Angélica, Beatriz, Duanne, Eduardo, Lígia, Letícia, Marcelo e Paulo.

Aos inúmeros amigos do Conjunto Residencial da USP - CRUSP.

Aos amigos da "turminha teen" da ETEc Aristóteles Ferreira de Santos - SP, Olívia, Paula, Roger, Samara, Simone, Thadeu, Thiago e demais, por crescerem comigo e por terem se vestido de meus personagens no FECAF.

Ao Hugo por ter me inspirado.

Ao Daniel por tudo. 


\section{Resumo}

SILVA, A. B. Intersecções entre as fotografias e a narrativa de Juan Rulfo. 153 p. Dissertação (Mestrado). Faculdade de Filosofia, Letras e Ciências Humanas. Universidade de São Paulo, 2015.

Este trabalho busca demonstrar a possível aproximação entre as fotografias e a narrativa de Juan Rulfo, em especial do romance Pedro Páramo, a partir da análise de três conceitos presentes em ambas obras, a saber, tempo, morte e história. A aproximação tem em conta as especificidades de cada uma das expressões artísticas desenvolvidas por Rulfo e não toma a sua fotografia como uma ilustração da narrativa ou vice-versa, como é comum ocorrer nas análises comparativas de suas obras. A análise dos conceitos abordados em uma e outra expressão artística do escritor-fotógrafo demonstra a problematização das mesmas questões tanto em suas fotografias como em sua narrativa a partir de abordagens distintas e, por vezes, oferecendo concepções contraditórias. A presença destes três conceitos nas produções artísticas de Juan Rulfo permite entrever que as questões que movem o seu trabalho artístico são análogas e que, através delas, podemos analisar sua obra como um todo.

Palavras-chaves: Juan Rulfo, Pedro Páramo, fotografia, tempo, morte, história. 


\begin{abstract}
SILVA, A. B. Intersecções entre as fotografias e a narrativa de Juan Rulfo. 153 p. Dissertação (Mestrado). Faculdade de Filosofia, Letras e Ciências Humanas. Universidade de São Paulo, 2015.

This research works to demonstrate the possible approximation between Juan Rulfos's photography and narrative, specially in the novel Pedro Páramo, from the analysis of three concepts present in both his oeuvre: time, death and history. This approach considers the specificity of each of the artistic expressions developed by Rulfo what avoids thinking about the photographs as illustrations of the narrative or vise versa. The analysis of the concepts addressed in both artistic expressions of the writerphotographer demonstrates the questioning of the same issues both in the photographs and in the narrative from distinct perspectives, what, sometimes, offers contradictory conceptions. However, the presence of these three concepts in Rulfo's artistic oeuvre allows us to detect that the questions that motivate his work are analogous and there through we can analyze his work as a whole.
\end{abstract}

Keywords: Juan Rulfo, Pedro Páramo, photography, time, death, history. 


\section{Resumen}

SILVA, A. B. Intersecções entre as fotografias e a narrativa de Juan Rulfo. 153 p. Dissertação (Mestrado). Faculdade de Filosofia, Letras e Ciências Humanas. Universidade de São Paulo, 2015.

Este trabajo busca demostrar la posible aproximación entre las fotografías y la narrativa de Juan Rulfo, en especial de la novela Pedro Páramo, desde el análisis de tres conceptos presentes en ambas obras: tiempo, muerte e historia. La aproximación lleva en cuenta las especificidades de cada una de las expresiones artísticas utilizadas por Rulfo y no toma su fotografía como una ilustración de la narrativa y vice-versa, lo que, muchas veces suele pasar en los análisis de sus obras. El análisis de los conceptos abordados en una y otra expresión artística del escritor-fotógrafo demuestra la problematización de las mismas cuestiones tanto en sus fotografías como en su narrativa desde abordajes distintos $\mathrm{y}$, por veces, ofreciendo concepciones contradictorias. La presencia de estos tres conceptos en las obras artísticas de Juan Rulfo permite entrever que los interrogantes que mueven su trabajo son análogas y que, a través de ellas, podemos analizar su obra como un todo.

Palabras-llaves: Juan Rulfo, Pedro Páramo, fotografía, tiempo, muerte, historia. 
Índice

Introdução 9

1. Os tempos da fotografia e da história 17

- O tempo: a (im)possibilidade da expressão 17

- Os tempos da fotografia 27

- Os tempos da fotografia de Juan Rulfo 35

- Pedro Páramo e a fotografia: possibilidades da expressão do tempo? 49

2. A dupla face da morte na escrita e na fotografia 66

- A morte no México 74

- A morte na fotografia 80

- A morte na fotografia de Rulfo 91

- Uma foice de dupla face: a morte como motivo em Pedro Páramo e nas fotografias de Rulfo 113

3. O tempo e a morte como suporte para a história nas obras de Rulfo 100

- A "verdadeira" inclinação 113

- As fotografias da história 124

- A história descontínua em Pedro Páramo 141

Conclusão, 152

Bibliografia, 157 


\section{Introdução}

Em 2010, foi lançado, no Brasil, pela editora Cosac Naif, o livro 100 fotografias: Juan Rulfo. O volume reúne um apanhado de cem fotografias deste reconhecido escritor mexicano. O lançamento foi realizado no mesmo ano em que a exposição de fotografias "México: Juan Rulfo, fotógrafo"1 esteve em cartaz em São Paulo (Memorial da América Latina) e no Rio de Janeiro (Instituto Cervantes). Seu trabalho fotográfico era quase desconhecido do leitor e do admirador de fotografia brasileiro, até então, salvo por trabalhos de Carlos Alberto Sampaio Barbosa, professor de História da Universidade Estadual de São Paulo, campus de Assis, e de Sebastião Guilherme Albano da Costa, professor do Departamento de Comunicação Social da Universidade Federal de Natal. Ambos escreveram sobre a produção visual do escritor-fotógrafo ${ }^{2}$.

Com pouco acesso às fotografias rulfianas no Brasil, tive o anseio de conhecer mais sobre esse trabalho. Observei, principalmente devido aos textos publicados no livro 100 fotografias, que os críticos ora ressaltavam a coincidência das temáticas nas fotografias e na escrita rulfiana, ora analisavam uma ou outra obra sem relacioná-las, com o receio de forçar afinidades que as distintas linguagens artísticas tornavam impossíveis. Identifiquei, portanto, um vazio na análise das obras de Juan Rulfo enquanto algo único, frutos da visão de mundo de um artista cuja bagagem intelectual excede a normalidade. Nesse sentido, o curador e pesquisador inglês Andrew Dempsey ressalta a necessidade de analisar as obras de Rulfo como "uma coisa só", Foi a partir dessa observação que o presente trabalho começou a tomar forma.

O trabalho fotográfico de Rulfo nasceu concomitantemente com sua escrita. Em 1945, Rulfo publicava "La vida no es muy seria en sus cosas" na revista América, da Cidade do México, e "Nos han dado la tierra" e "Macario"

\footnotetext{
1 Título referente ao livro de fotografias homônimo, lançado um ano antes pela editora espanhola Lunwerg. Rulfo, Juan. México: Juan Rulfo, fotógrafo. Barcelona: Lunwerg Editores, 2001.

${ }^{2}$ BARBOSA, Carlos Alberto Sampaio, "Escritura em Chamas - Fotografia de Fogo: Juan Rulfo, escritor e fotógrafo", In: Anais Eletrônicos do VII Encontro Internacional da ANPHLAC. Campinas, 2006 (http://anphlac.org/upload/anais/encontro7/carlos_alberto_s_barbosa.pdf) Último acesso em 18/04/2013 e Costa, Sebastião Guilherme Albano. A modernidade representada na América Latina. Natal: EDUFRN, 2009.

${ }^{3}$ Dempsey, Andrew. "Um estrangeiro em busca de Juan Rulfo". In: 100 fotografias: Juan Rulfo. São Paulo: Cosac Naif, 2010, p. 15.
} 
nesta mesma revista e na revista Pan, de Guadalajara ${ }^{4}$. Em 1949, quando Rulfo atuava como colaborador da revista América, teve publicada sua primeira mostra de fotografias intitulada "11 fotografías de Juan Rulfo", sem legendas ou qualquer texto que as acompanhasse. O fotógrafo também publicou várias fotografias na revista Mapa: Automovilismo y Turismo de que era colaboradora a empresa de seu tio, Goodrich-Euzkadi, onde trabalhou de 1946 a 1952. A revista, além das fotografias de Rulfo, chegou a publicar trabalhos de fotógrafos renomados no momento, como Manuel Álvares Bravo e Hugo Brehme.

Atuou na empresa, primeiramente, como subgerente e, depois, como agente de vendas. Devido a este último posto, Rulfo pôde viajar por diversas regiões do país, sempre munido de sua câmera Rolleiflex ${ }^{6}$ com que tirava centenas de fotografias. Mais tarde, tornou-se diretor da revista Mapa e lá pôde publicar a fotorreportagem "Metztitlán: lugar junto a la luna" em que se encontram fotos da região de Meztitlán, localizada no estado de Hidalgo, e se destacada a história da construção do Convento de los Santos Reyes ${ }^{7}$. É interessante notar que o título da fotorreportagem alude a um dos primeiros títulos de seu romance canônico. Antes de chamar-se Pedro Páramo, o romance fora intitulado de Una estrella junto a la luna. Ainda que a fotorreportagem tratasse de uma construção colonial, a estrela presente no título remete à cosmogonia pré-hispânica representada pela figura da deusa Xólotl associada à estrela da tarde. Esse deslocamento entre história préhispânica e história colonial e moderna será recorrente na obra fotográfica e literária do escritor-fotógrafo.

4 Vital, Alberto. Noticias sobre Juan Rulfo: 1784-2003. Cidade do México: Editorial RM/UNAM/Universidad de Guadalajara/Universidad Autónoma Aguascalientes/Universidad de Tlaxcala/F.C.E., 2003.

${ }^{5}$ Vargas, Paulina Millán. La difusión inicial de las fotografías de Juan Rulfo (1949 - 1964). [online] Disponível em <http://juan-rulfo.com/NI_Paulina_Millan.pdf>. Acesso em 7 de dezembro de 2015.

${ }^{6}$ Embora haja controvérsia em relação à câmera utilizada por Rulfo nos depoimentos de alguns de seus amigos, é bastante provável que as suas fotos tenham saído de uma Rolleiflex, conforme afirma Paulina Millán Vargas em trabalho sobre as fotografias de Juan Rulfo. In: Vargas, Paulina Millán. Trayectoria fotográfica de Juan Rulfo. Una visión panorámica (1917- 1962). 2008. (Trabalho de Conclusão de Curso de Licenciatura em História) Facultad de Filosofía y Letras, Colegio de Historia, Universidad Nacional Autónoma de México, D.F., México.

${ }^{7}$ Vargas, Paulina Millán. La difusión inicial de las fotografías de Juan Rulfo (1949 - 1964). [online] Disponível em <http://juan-rulfo.com/NI_Paulina_Millan.pdf>. Acesso em 7 de dezembro de 2015, passim, p. 6. 
Em 1958, Rulfo publica sete fotografias em um artigo intitulado "The Papaloapan" na revista Mexico/This Month que já havia trabalhado com nomes como Héctor García, Nacho López e os irmãos Mayo. Essa é a primeira de outras participações de Rulfo na revista, contudo, a única em que suas fotografias estão acompanhadas de um texto que fala do projeto travado com o engenheiro Raúl Sandoval na região do rio Papaloapan, no estado de Oaxaca. O então fotógrafo e o engenheiro partem para essa região em busca de melhorias para a população carente local ${ }^{8}$.

Dois anos depois da missão do Papaloapan, Rulfo tem sua primeira exposição de fotografias realizada na Casa de Cultura, em Guadalajara. Recuperada pelo testemunho de Lon Pearson, a exposição exibia 23 fotografias e ficara esquecida por muito tempo em que se considerou que sua primeira exposição fotográfica tinha sido realizada em $1980^{9}$. A mais aclamada das exposições de fotografias de Juan Rulfo foi realizada seis anos antes de sua morte. Intitulada "El mundo de Juan Rulfo", a exposição fazia parte da homenagem nacional realizada pelo Instituto Nacional de Bellas Artes e inaugurada pelo então presidente José Lopez Portillo. ${ }^{10}$

As fotografias de Rulfo dialogavam com o que vinha sendo produzido em seu país. Na primeira década do século XX, a inserção do México na modernidade tornava pungente a necessidade de busca pela identidade nacional. A consolidação do capitalismo revelava as perdas após a revolução mexicana e a crescente desigualdade social no país, com a extrema marginalização dos indígenas. Dentro dessa realidade, muitos artistas centraram suas buscas em "lo mexicano", opondo-se às ideologias imperialistas que se impunham, notavelmente norte-americanas, e revitalizando os ideais revolucionários. Também, a efervescência política fazia com que as câmeras registrassem os principais acontecimentos do país, dando sequência às emblemáticas fotografias da Revolução Mexicana como a das soldaderas na plataforma do trem na estação Buenavista (1912), na Cidade do México, de Gerónimo Hernández, e a imagem dos refugiados das zonas de confronto durante a Decena Trágica (1913), também na capital mexicana, dos irmãos

\footnotetext{
${ }^{8}$ Ibidem, p. 15.

${ }^{9}$ Ibidem, p. 21.

${ }^{10}$ Ibidem. p. 3.
} 
Casasola. A foice, a cartucheira e a espiga de milho, fotografadas por Lola Álvarez Bravo (1928), recorre à estetização dos conflitos dessa época com uma fotografia ao mesmo tempo artística e engajada.

As fotografias da modernidade chegam equilibrando-se nas barras de ferro em que caminha o operário fotografado pelos irmãos Mayo na construção da ostentadora Torre Latino-americana (1951) no centro da Cidade do México. Chega pontuada pelo olhar em "contra-mergulho" de Gabriel Figueroa em suas fotografias e filmes. Em Río escondido, de Emilio Fernandez, a ilustre atriz María Félix é fotografada de baixo para cima em contraste com a paisagem cinzenta e suas vestes negras. A fotografia de Los olvidados (1950), filme em que Figueroa trabalha com Luis Buñuel, retrata a pobreza que assola a periferia da Cidade do México com o mesmo contraste sombrio. O contraste entre claro e escuro, luz e sombra e o olhar em contra-plogeé será algo bastante presente nas fotografias de Rulfo.

Ao lado de nomes como os dos irmãos Mayo, Nacho López e Héctor García, Juan Rulfo desponta com uma série de fotografias que evidencia uma elevada qualidade profissional. Essa qualidade pode se dever ao fato de que, em sua biblioteca pessoal, figuravam mais de 700 títulos voltados à fotografia. Embora nunca tenha aceito o título de fotógrafo, nem mesmo por alguém como Nacho López, Rulfo, sem dúvida, tinha consciência de seu potencial. Autodidata, investiu uma grande soma em sua câmera profissional e pôde aplicar conhecimentos bastante precisos a respeito do ato fotográfico com sua Rolleiflex que estava longe do domínio de um fotógrafo amador familiarizado com as Leica instantâneas do primeiro quinquênio do século passado.

As fotos que serão analisadas neste trabalho são um pequeno apanhado de sua extensa produção visual feita ao longo de sua vida. Abarcam temas variados, desde ruínas, arquitetura, paisagens, indígenas até a modernidade. Todas as fotografias aqui reproduzidas foram publicadas em livros no México ou no exterior. O público ainda hoje desconhece grande parte das fotografias que se encontra sob os cuidados da Fundação Juan Rulfo, dirigida pelo arquiteto Víctor Jiménez e presidida pela viúva Clara Aparicio. Atualmente, a fundação atua na datação dessas fotografias, encontradas, muitas vezes, com quase nenhuma anotação relevante que pudesse localizar a paisagem retratada 
ou que se referisse à data de sua tomada. Paulina Millán Vargas é a pesquisadora que tem se voltado para essa tarefa.

Em contrapartida, a reduzida produção literária de Rulfo foi esmiuçada por uma vasta fortuna crítica. Os contos de El llano en llamas (1953) e o romance Pedro Páramo (1955) intrigaram críticos e amantes da literatura de todo o mundo. O cinema, inspirado pelas ricas imagens poéticas que Rulfo constrói em seus escritos, voltou-se a sua obra com afinco. São várias as adaptações de suas obras para as telas: Talpa (1956) por Alfredo Crevenna, Macario (1960) por Roberto Galvadón, Pedro Páramo (1967) (adaptação de roteiro feita por Carlos Fuentes e Gabriel García Márquez) por Carlos Velo, El rincón de las vírgenes (1972) (adaptação dos contos "Anacleto Morones" e "El día del derrumbe"), No oyes ladrar los perros (1974) por François Reichenbach, Que esperen los viejos (1976) (inspirado em vários textos de Rulfo) por José Luís Bolaños, El hombre (1978) por José Luís Serrato, Talpa (1982) por Gastón T. Melo, Pedro Páramo (1978) por José Luís Bolaños, Tras el horizonte (inspirado no conto "El hombre") por Mitl Valdez, Diles que no me maten (1985) por Freddy Siso, Los confines (1988) (inspirado no romance Pedro Páramo e nos contos "Diles que no me maten" e "Talpa") por Mitl Valdez. Além dessas adaptações, ainda desponta El gallo de oro, novela escrita por Rulfo, publicada postumamente e adaptada para o cinema por Roberto Galvadón.

Essa vasta lista de obras cinematográficas realizadas a partir de obras de Rulfo demonstra que há uma inquestionável potência visual em sua escrita. Isso não significa dizer, contudo, que sua produção visual seja reflexo da visualidade de seus textos. Mas, faz crer que trabalhar as duas obras em conjunto não parece o disparate de alguém que não é capaz de perceber a duplicidade do trabalho artístico do escritor-fotógrafo. A narratividade está presente em suas fotografias, assim como a visualidade se destaca em seus escritos. Portanto, para viabilizar a pesquisa, detive-me no romance Pedro Páramo ao contrapor as fotografias à narrativa e ao apontar os pontos de intersecção entre uma expressão artística e outra. É digno de nota que um romance tão curto possa condensar tamanha potência para páginas e mais páginas de crítica que, de forma alguma, se esgotarão neste trabalho. 
Para fazer despontar a potência interartística de suas obras e realizar a intersecção entre produção visual e escrita literária de Juan Rulfo, identifiquei três conceitos recorrentes tanto em uma como em outra expressão. Através da análise do funcionamento do tempo, da morte e da história em sua fotografia e em sua literatura, é possível identificar a origem daquela narratividade fotográfica e visualidade narrativa destacadas acima.

Ainda, através da análise desses temas, pode-se notar que, ao compor suas fotografias e narrativas, Rulfo se vale de seu vasto conhecimento em diversas áreas do saber e, por isso, desafia o pesquisador. As duas expressões percorridas por ele demonstram o trabalho de um intelectual que pôde produzir uma obra artística heterogênea, moderna e clássica. Ao longo da pesquisa que possibilitou este trabalho, ao conhecer mais sobre seus escritos e fotografias, ouvir anedotas daqueles que conviveram com ele, e descobrir seus rascunhos e apontamentos, muitas das minhas hipóteses levantadas no início da pesquisa foram, de certa forma, embasadas. Os três conceitos a que me dediquei neste trabalho, o tempo, a morte e a história, estavam presentes na gênese de suas obras, eram temas de seus escritos mais íntimos, foram pensados, repensados e recriados em suas produções. Isso possibilitou a conclusão dessa pesquisa.

No início do trabalho, deparei-me com um tema extremamente denso e trabalhoso: o tempo. É disto que tratará o primeiro capítulo desta dissertação: “Os tempos da literatura e da fotografia”. Foi necessário recorrer à filosofia, clássica e moderna, para adentrar nesse campo pelo qual percorreu Rulfo na sua dupla composição artística. Através da aproximação de certa teoria da imagem, que trata da heterogeneidade do tempo na fotografia, com a heterogeneidade do tempo destacada pelos críticos literários da obra narrativa rulfiana pude realizar a esperada intersecção entre as obras.

Num segundo momento, quando estive na Cidade do México e pude viver um pouco, mesmo que descontextualizada, da cultura de Rulfo, voltei-me para o tema da morte que resultou no segundo capítulo da dissertação: "A dupla face da morte na fotografia e na escrita rulfianas". Partindo primeiramente da questão da concepção da morte no México, emblemática por excelência, e seguindo para as alusões da morte com o ato fotográfico e a morte como tema de sua narrativa, foi possível reconhecer uma possível aproximação. 
Por último, encerrando o trabalho, voltei-me à história em "O tempo e a morte como suporte para a história nas obras de Juan Rulfo". Incursionando pelo estudo da História da América, desde a América Pré-hispânica até a América Independente, além da Teoria da História, encontrei Juan Rulfo e pude regressar às suas obras. Descobri algo de suas fotografias nas descrições das crônicas espanholas e algo de sua narrativa nas releituras dos pictogrifos pré-hispânicos. Suas duas expressões artísticas estavam embebidas de conceitos e visões caras à historiografia e à teoria da história.

Através deste trabalho, busco oferecer ao estudioso das obras de Rulfo, tanto fotográfica como narrativa, uma oportunidade de visualizar um conjunto heterogêneo, mas que perpassa, muitas vezes, os mesmos caminhos.

Pensar em tempo, morte e história como conceitos atrelados à longa trajetória pela qual a definição de "conceito" vem passando, desde os filósofos clássicos até os contemporâneos, permite perceber a tentativa de se acercar a eles de maneira cuidadosa. Os conceitos remetem a um domínio do conhecimento e podem realizar associações entre si ao delimitar objetos e suas características $^{11}$. Nesse sentido, tendo em vista os três conceitos ressaltados aqui, busca-se analisar e delimitá-los um em relação ao outro. Ao apontar essa trajetória na definição de conceito, Francelin e Kobashi ${ }^{12}$ aproximam-se do que chamam de "processo classificatório" e, logo, associam-no à discussão de categoria, que seria cara para a prática da classificação apontada. A associação entre essa ideia de classificação através dos conceitos com a de categoria os leva à imagem da árvore Baniana de Ranganathan e do rizoma de Deleuze e Guattari. O que nos é interessante nessa postulação é justamente o fato de que discorrer sobre a questão do conceito leva os autores à imagem do conhecimento como algo ramificado e, no caso do rizoma, sem uma raiz única como origem.

Ainda que sejam ramos distintos da expressão artística, a obra fotográfica e narrativa de Rulfo está articulada em torno de conceitos análogos que apresentam subdivisões internas e podem englobar ou desassociar-se de outros conceitos dependendo da linguagem que os expressa, visual ou escrita.

${ }^{11}$ Francelin, Marivaldi Moacir. Kobashi, Nair Yumiko. "Conceitos, categorias e organização". In: Informação \& Informação. v. 16, número especial, 2011. Universidade Estadual de Londrina. ISSN 1981-8920.

${ }^{12}$ Idem. 
Essa acepção dos conceitos de tempo, morte e história possibilita visualizar a pluralidade e a extensão de significados nas obras de Rulfo. Desse modo, não afirmo que Rulfo trata o tempo, a morte e a história da mesma forma em suas expressões artísticas, mesmo porque, devido a sua inegável diferença, não seria possível abarcar um e outro tema exatamente de igual maneira a partir de recursos linguísticos, na escrita, e de recursos físicos e químicos, na fotografia. Reivindicando a palavra "conceito" para os três pontos principais que percorrerão as obras em análise, busco salientar a pluralidade de seus significados mesmo quando presentes na produção de um mesmo autor. Não busco homogeneizar nem a obra nem o sujeito por detrás dela, mas viabilizar um panorama a partir do qual é possível verificar toda a complexidade e a heterogeneidade que compõe o todo.

Dito isto, podemos prosseguir. 


\section{Capítulo 1 - Os tempos da fotografia e da literatura}

O tempo: a (im)possibilidade da expressão.

Nas primeiras linhas do romance, o leitor de Pedro Páramo ${ }^{13}$ (1955), se depara com uma narrativa que começa linearmente com a ida de Juan Preciado a uma cidade interiorana para encontrar o pai de quem deve cobrar o esquecimento a que o submeteu junto com sua mãe. Falecida há sete dias, a mãe, em seu leito de morte, fez com que Juan Preciado prometesse cumprir a façanha. No caminho da cidade buscada, o filho se encontra com um arrieiro de poucas e quase sempre irônicas palavras quem o apresenta à Media Luna, localizada "en la mera boca del infierno"14. "Abundio" é como se apresenta o arrieiro ao ir embora, não permitindo com que Preciado ouvisse o seu sobrenome, que aparentemente se esvanece com a distância entre os dois. Quando Juan Preciado já se encontra bastante próximo de Comala, o guia se faz desnecessário. É neste ponto, então, que a narrativa dá um pequeno salto no tempo da história. No fragmento que segue à despedida do arrieiro, sem mediação do narrador, uma mulher se apresenta como Eduviges Dyada e conduz seu visitante, que logo sabemos tratar-se de Juan Preciado, pelo interior de uma casa fantasmagórica. Logo mais adiante na narrativa, saberemos

\footnotetext{
${ }^{13}$ Único romance publicado por Juan Rulfo, dois anos após a publicação de seu primeiro e também único livro de contos, El llano en llamas (1953) que, ao lado de El gallo de oro (adaptado por Roberto Gavaldón e Carlos Fuentes para o cinema em 1964), seguido de outros pequenos roteiros, comporá a breve obra literária do autor. Ainda assim, Pedro Páramo ressoa como um dos principais romances publicados na América Latina. Será este romance que nos servirá de base para a análise do tempo na escrita de Juan Rulfo.

14Rulfo, Juan. Pedro Páramo. Madri: Cátedra, 2011, pp. 8-9. Está será a edição referida nas próximas citações do romance.
} 
também que fora o próprio Abundio que aconselhara Preciado a buscar esta mulher.

Os demais fragmentos que compõem a narrativa de Pedro Páramo não serão tão bem aclarados àquele leitor que avançar no romance. Isto, porque os saltos no tempo da história se tornarão cada vez mais altos e, por vezes, o tempo narrativo rodopiará sobre si mesmo, compondo fragmentos em que passado e presente parecem indistinguíveis. O tempo se revela, então, como uma importante chave para a compreensão do romance rulfiano e é, também, um elemento essencial para a análise da obra visual ${ }^{15}$ do autor. É, portanto, e primeiramente, sobre o tempo que recai a nossa atenção para a análise das obras do escritor-fotógrafo mexicano.

A célebre afirmação de Santo Agostinho, nas Confissões, a respeito do tempo chega a sugerir certa esquiva na definição deste conceito que perturbou toda a vida do filósofo religioso. "O que é, pois, o tempo? Se ninguém mo pergunta, sei o que é; mas se quero explicá-lo a quem mo pergunta, não sei”" ${ }^{16}$. A expressão do tempo em palavras é referida já nos pensamentos deste filósofo como um problema aparentemente insolúvel. O que Santo Agostinho aponta, contudo, é que a falta de uma linguagem que exprima o tempo não o reduz à ininteligibilidade. “... [C]omo é que eu sei isso, quando não sei o que é o tempo?"17 , pergunta-se o filósofo. É a impossibilidade da consumação da ação comunicativa que o inquieta, o que nos aproxima à grande tarefa dos filósofos modernos que o sucederão, principalmente a partir do Iluminismo, quando a razão passa a guiar a consciência humana para a definição das coisas do

\footnotetext{
${ }^{15}$ Refiro-me à sua extensa produção fotográfica, publicada em diversos livros no México e no exterior, e que permanece sob o zelo da Fundación Juan Rulfo, localizada na Cidade do México. ${ }^{16}$ Santo Agostinho. Confissões, IN-CM, Lisboa, 2001, p. 113.

${ }^{17}$ Ibidem, p. 124
} 
mundo. A modernidade confiará ao homem a definição de ser comunicativo por excelência, o conhecimento passará a ser evocado como um bem compartilhável, os saberes deverão ser comunicáveis ${ }^{18}$. Santo Agostinho, no século IV, lamenta não poder comunicar o tempo ${ }^{19}$; à posteridade, portanto, recai a tarefa de fazê-lo. Mas, como comunicar e, por consequência, compartilhar essa experiência? É possível expressar nossa experiência com o tempo?

Segundo Norbert Elias, o tempo é comunicado entre os seres humanos através de um símbolo social que permite com que "a ideia de tempo" transmita "de um ser humano para outros imagens mnêmicas que dão lugar a uma experiência"20. Essas "imagens mnêmicas" aceleram a aprendizagem de certas "instituições" construídas ao longo de um lento e extenso desenvolvimento da sociedade, como a própria instituição do tempo. O tempo não é, porém, apenas uma ideia humana, despegada da natureza. Tampouco é apenas um dado natural, como um rio caldoso que corre levando em suas águas toda a sociedade ou um animal feroz que devora as coisas ao redor. Segue aquele autor: “(...) a noção do tempo representa uma síntese de nível altíssimo, uma vez que relaciona posições que se situam, respectivamente, na sucessão de

\footnotetext{
${ }^{18}$ A ação comunicativa, postulada por Jürgen Habermas, é alocada na sociedade moderna em contraposição à sociedade mítica, em que a visão sujeito-objeto deduzia um caráter unificador do mundo. Na era moderna, a comunicação se dá entre os sujeitos (sujeito-sujeito), buscando-se, com essa relação, um entendimento comum entre os atores comunicativos envolvidos que alie a visão individual de cada um deles à visão social e histórica dos objetos do mundo.

José Marcelino de Resende Pinto analisa a ação comunicativa de Habermas em relação ao âmbito administrativo escolar em: Pinto, José Marcelino de Resende. "A teoria da ação comunicativa de Habermas: conceitos básicos e possibilidades de aplicação à administração escolar". In: Revista Paidéia [on-line]. N.8-9: Ribeirão Preto, Faculdade de Filosofia, Ciências e Letras de Ribeirão Preto, 1995. Disponível em $<$ http://www.scielo.br/scielo.php?pid=S0103-

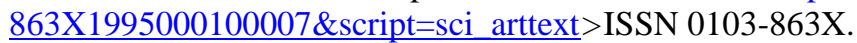

19 Em De Magistro, de 389, Agostinho discorre sobre a incompreensão na linguagem, colocando que o diálogo não é a melhor forma de alcançar a verdade.

${ }^{20}$ Elias, Nobert. Sobre o tempo. Rio de Janeiro: Jorge Zahar, 1998, p. 13. 
eventos físicos, no movimento da sociedade e no curso de uma vida individual" $" 21$.

Percebemos uma concepção do tempo que recorda as postulações de Elias em um conto do escritor novecentista brasileiro, Machado de Assis ${ }^{22}$. Em "Papeis velhos", o narrador se depara com antigas cartas de amor e, lendo uma frase escrita na dobra de um dos papeis, “[u]m só minuto do teu amor, e estou pronto a padecer um suplício et...", ele nota: "[u]ma traça bifara o resto da palavra; comeu o eterno e deixou o minuto. Não se pode saber a que atribuir essa preferência, se à voracidade, se à filosofia das traças"23. São as traças vorazes que comem o papel, e não o próprio tempo que permitiu com que esse fenômeno ocorresse. A filosofia mencionada pelo personagem pertence às traças e, novamente, não ao tempo, que se deixa revelar pela ação dessas terceiras nos papeis velhos. O tempo, no conto, escapa até mesmo à filosofia, como já advertia Santo Agostinho. As lembranças rememoradas através dos escritos, somadas àquela manifestação natural da passagem do tempo, permitem a sua inferência pelo personagem leitor. Os relógios que soam durante a noite insone em que se depara com os escritos do passado são, por sua vez, os símbolos sociais que lhe traduzem o tempo. Em outras palavras, as badaladas dos relógios desajustados que ouve o personagem, dissonantes com os ecos do relógio que tem próximo a si, ajustado, denunciam a convenção arbitrária adotada pela sociedade para a medição do tempo.

\footnotetext{
${ }^{21}$ Ibidem, p. 17

${ }^{22}$ Juan Rulfo, autor cuja obra é nosso enfoque nesta pesquisa, escreveu um prólogo à versão em espanhol de Memórias Póstumas de Brás Cubas de Machado de Assis, publicado no México em 1982. No prólogo, Rulfo destaca como característica do escritor brasileiro "um lenguaje nuevo, evocador y lleno de matices hasta entonces no experimentados por otros autores". Rulfo, Juan. Toda la obra. "[Machado de Assis]". Madri; Paris; Cidade do México; Buenos Aires; São Paulo; Rio de Janeiro: ALLCA XX/Edusp, 1996, p. 437-439.

${ }^{23}$ Assis, Machado de. Papéis velhos. Disponível em <http://www.dominiopublico.gov.br/download/texto/bv000226.pdf〉, p. 6. Acesso em 29/09/2013.
} 
Portanto, entendemos a definição do tempo vinculada ao trípode natureza/sociedade/indivíduo. Os mecanismos que fazem com que ele se insira na sociedade, nos termos expostos anteriormente, são importantes para Elias. Instrumentos como o relógio ou o papel tragado por traças, citado no conto machadiano, podem ser comparados aos instrumentos que o sociólogo afirma compor as unidades de referência utilizadas para a determinação do tempo pela sociedade moderna ${ }^{24}$. Dessa forma, um relógio ou um calendário, o primeiro através das horas, minutos e segundos indicados por seus ponteiros, o segundo com dias, meses e anos, parecem traduzir o tempo ao homem. Essas duas referências do tempo podem nos levar a inferir que o tempo são duas horas da tarde, da mesma forma como o tempo é o dia 14 de setembro de 2013. Porém, essa relação que denota uma definição arbitrária do símbolo do tempo é relativizada pela linguagem, como notou Agostinho. E, para nós, tanto a linguagem literária como a fotográfica, ou seja, não apenas a linguagem verbal, são elas mesmas essencialmente arbitrárias.

Ainda que remetam a um marco no calendário, algumas narrativas, como Pedro Páramo de Juan Rulfo ou, para ampliar o espectro, uma obra mais contemporânea como Glosa ${ }^{25}$ (1985) de Juan José Saer, mais explicitamente, quando o fazem, tratam de compor para o tempo referências híbridas em que a realidade extratextual é uma de suas possibilidades. Ou seja, o que por vezes

\footnotetext{
24 “O movimento aparente do Sol, de um ponto a outro do horizonte, assim como o movimento dos ponteiros de um relógio de um ponto do mostrador a outro, são exemplos de sequências recorrentes que podem servir como unidades de referência e meios de comparação para segmentos de processos pertencentes a uma outra série e que não podem ser diretamente relacionados, em razão de seu caráter sucessivo. Em sua qualidade de símbolos reguladores e cognitivos, essas unidades de referência adquirem a significação de unidades de tempo". Elias, Norbert. Op. Cit. p. 13. Essas "sequências recorrentes" são desfeitas em Pedro Páramo, como se notará mais adiante. Quando o personagem Juan Preciado olha para o céu de Comala e se depara com o movimento de nuvens e estrelas é quando perde totalmente a sua referência temporal e acaba morrendo.

25Romance publicado em 1986, na Argentina, que trata da caminhada de dois amigos pelas ruas de Santa Fé, durante a qual retomam detalhes do aniversário de um amigo em comum, evento ao qual nenhum dos dois esteve presente.
} 
pode parecer uma referência pontual, nestas obras, é, na verdade, apenas uma sugestão do tempo da história que se borrará com o desenvolvimento da trama narrativa.

Em Pedro Páramo, por exemplo, a menção à Guerra Cristera pode nos levar ao calendário e compreender que o tempo narrativo se refere aos anos de 1926 a 1929, assim como a citação de carrancistas e obregonistas nos leva à mesma década, devido à oposição política que se iniciou em $1920^{26}$ pelo poder pós-revolucionário mexicano. Porém, esses referentes temporais se perdem na narrativa embebida no tempo dos mortos. Dorotea, ao perguntar o que ouvira Juan Preciado de Susana San Juan, enterrada próximo a eles, diz: “Pero de qué tiempos hablará [Susana]?”27. O tempo em que se localizam os acontecimentos históricos e o tempo instável das lembranças expressadas pelos murmúrios do povo de Comala formam, em conjunto com o tempo dos mortos, compõem o tempo híbrido que fundamenta o romance.

O romance do argentino José Juan Saer, Glosa, por seu lado, inicia a narrativa problematizando justamente o referente temporal que vincularia a narrativa à realidade extratextual: "Es, si quiere, octubre o noviembre, del sesenta o del sesenta y uno, octubre tal vez, el catorce o el dieciséis, o el ventidós o el veintitrés de octubre de mil novecientos sesenta y uno pongamos - que más $d a^{\text {"28 }}$. Novamente, o tempo da história narrada no romance não é apenas o tempo referencial extraliterário, um tempo fixo circulado arbitrariamente numa folha de calendário, cinco anos antes do golpe que iniciaria o período da ditadura argentina, mas é também o tempo da memória,

\footnotetext{
${ }^{26}$ No terceiro capítulo de nossa dissertação, esses eventos históricos serão retomados com maior atenção.

27 Pedro Páramo, p. 84.

28Saer, Juan José. Glosa. Buenos Aires: Alianza Editorial, 1986, p. 15.
} 
que se desloca nas lembranças dos personagens e que, como em Pedro Páramo, avança e se detém quase involuntariamente, tornando, mais uma vez, o tempo narrativo um tempo híbrido.

No caso da fotografia, por sua vez, ainda que uma foto seja tirada a uma determinada hora do dia, essa hora exata não é impregnada na imagem revelada que apresenta o tempo em um alto grau de problematização. As ruínas fotografadas por Rulfo, por exemplo, demonstram a passagem do tempo, mas não o flagram objetivamente. Sob o trabalho minucioso do escritor e do fotógrafo, a linguagem que envolve essas artes pode construir instrumentos mais complexos do que os instrumentos mecânicos utilizados para a marcação do tempo que rege nossa vida cotidiana, como relógios e calendários.

Literatura e fotografia, quando voltadas à problemática do tempo, evocam referências complexas que revelam a sua passagem de maneira que podemos vislumbrar menos a vinculação imediata do tempo com a realidade objetiva, do que algo de seu aspecto, uma temporalidade nebulosa. Na linguagem que envolve as duas formas de expressão apontadas, quando expressas por escritores e fotógrafos empenhados na denúncia da arbitrariedade do tempo, podemos contemplar vestígios do silêncio que envolve a sua definição buscada por eles. Essas linguagens esbarram na definição do conceito e ao mesmo tempo escapam à essa definição por serem impossibilitadas de tal expressão. Ao se apoderar das duas formas de arte, Juan Rulfo armou-se de linguagens que permitem vislumbrar a posta em cena do tempo como um conceito que é propriamente fugitivo à linguagem humana. Através de sua escrita e com sua câmera fotográfica, busca caminhos para cercar o conceito do tempo, para expressá-lo através de imagens literárias e imagens visuais, mas, 
consciente dessa impossibilidade, apenas persegue-o sem nunca apreendê-lo em nenhuma das duas formas de expressão.

No que concerne à crítica literária em relação à primeira dessas formas de expressão, a literária, e fugindo do caráter do tempo "incomunicável” por ora ressaltado, diversos autores reduzem a análise do tempo no romance de Rulfo às cifras do tempo histórico. Gustavo Fares, por exemplo, em seu livro Imaginar Comala ${ }^{29}$, faz uma detida análise do "referente temporal"30 de Pedro Páramo. Este referente diz respeito ao marco histórico em que se daria a narrativa. Através de diversas induções, o autor chega a datar o nascimento e a morte de Don Pedro Páramo, além de definir sua idade, contrapondo os acontecimentos sucessivos, montados como peças de um quebra-cabeça, aos acontecimentos históricos que vivia o México da época. ${ }^{31}$

A aproximação ao tempo histórico é realizada apenas se deslocados os fragmentos para uma sequência que não aquela idealizada por Rulfo. Autores como Miguel Guardia, Ricardo Garibay e Ali Chumacero criticaram o romance nos primeiros anos de seu lançamento por sua suposta falta de estrutura narrativa, o que esbarra no fato de que ele não se adequa à redução do tempo cronológico "real", como se a impossibilidade de ligar a obra à realidade extraliterária reduzisse seu valor. ${ }^{32}$ Esses críticos estavam certos de alguma

\footnotetext{
${ }^{29}$ Fares, Gustavo C. "1. El espacio en la obra de Rulfo. A. Referente temporal”. In: Imaginar Comala, Nova Iorque: Peter Lang Publishing, 1991

${ }^{30}$ Ibidem, p. 7.

${ }^{31}$ É interessante notar a diferença entre a tentativa de datação dos eventos narrados no romance por Fares e a datação das fotos de Juan Rulfo que a pesquisadora Paulina Vargas Millán, sob supervisão da Fundação Juan Rulfo, realiza. A primeira é uma tarefa impossível, uma vez que, como veremos adiante, o tempo da narrativa é desconstruído pela imposição da morte intermediadora dos murmúrios que narram a história do povo de Comala. A segunda tarefa, através do labor historiográfico, é completamente possível. Porém, a objetividade da data marcada nas fotos não reduz a subjetividade do passado ali representado, construído através das intenções do fotógrafo.

${ }^{32} \mathrm{O}$ próprio Rulfo, no prefácio da edição de aniversário de trinta anos de Pedro Páramo elenca esses e outros críticos e suas postulações negativas perante a obra: "Miguel Guardia encontraba en el manuscrito sólo un montón de escenas deshilvanadas. Ricardo Garibay, siempre
} 
maneira: realmente, em Pedro Páramo, não é possível realizar aquela redução sem grandes problemas para a construção dos argumentos que a sustentariam.

O problema em identificar o tempo narrativo na obra em questão ocorre devido a dois elementos. O primeiro: os murmúrios constituem toda a narração de Pedro Páramo e são emitidos desde as tumbas em que estão enterrados seus emissores; e é justamente no subsolo que se "espacializa" o romance. O espaço é, ironicamente, a clausura das tumbas em que os personagens constroem seu discurso. O segundo: o tempo evocado por este discurso é completamente movediço, uma vez que os pensamentos percorrem a vida desde a morte, com total liberdade para saltos e regressões realizados através dos fragmentos descontínuos que compõem o romance, impedindo com que os discursos se firmem em um tempo específico. Esse terreno inseguro formado pelo tempo permite, portanto, com que os personagens emitam murmúrios insólitos capazes de matar seus ouvintes, em lugar de uma fala plena e vivificante. Dessa forma, tempo e espaço do romance fogem de maneira evidente à estrutura canônica do romance histórico, que faz a representação da "realidade objetiva" se sobrepor "às intenções subjetivas"33 do autor. Conforme a definição do tempo buscada nesta pesquisa, a subjetividade é um de seus elementos essenciais.

O espaço de Pedro Páramo é dado como um quase não espaço, é um confinamento. O tempo, por sua vez, ainda que insólito, deixa-se provar, pois de outra forma não teríamos a narrativa construída pelo povo de Comala que

vehemente, golpeaba la mesa para insistir en que mi libro era una porquería”. (...) “Archibaldo Burns hizo la primera reseña, negativa, en México en la Cultura, el gran suplemento que dirigía en aquellos años Fernando Benítez, con el título de 'Pedro Páramo o la unción y la gallina', que jamás supe qué diantres significaba. En la Revista de la Universidad, el propio Alí Chumacero comentó que a Pedro Páramo le faltaba un núcleo al que concurrieran todas las escenas". Apud Martin, Gerard. "La primera década: Juan Rulfo, escritor mexicano". In: Rulfo. Juan. Toda la obra. Op. Cit., p. 586.

${ }^{33}$ Lukács, György. O romance histórico. São Paulo: Boitempo, 2011, p. 299. 
guia Juan Preciado à revelação de sua própria morte. Assim, percebemos que as referências históricas em Pedro Páramo criam certa familiaridade da obra com a realidade objetiva, porém, não definem pragmaticamente o tempo do romance. Em outras palavras, toda a narrativa tem um parentesco com a realidade extraliterária, mas não podemos reduzir sua interpretação às cifras dos acontecimentos que a rodeiam, principalmente em Pedro Páramo. As alusões a referentes temporais extraliterários não são pistas perdidas em uma narrativa fragmentada pedindo para que seja desfeito seu mistério. Não é o desvendamento de um mistério ligado à realidade extraliterária o tipo de tarefa que se requer daquele leitor do romance rulfiano evocado no começo de nossa exposição. O mistério de Pedro Páramo é de outra ordem.

O tempo da narrativa do romance, ao contrário do que poderia levar a pensar a leitura de grande parte da fortuna crítica rulfiana, portanto, é uma base quase perdida propositadamente, assim como os personagens deixaram, ou foram obrigados a deixar, com que a vida lhes escapasse. Tanto o tempo como a vida não podem, jamais, ser recuperados em sua plenitude. Os referentes, no modo como foram buscados por Fares e por outros críticos com ainda maior fôlego antes dele estão, de certa forma, perdidos.

Para a nossa análise do tempo partimos de Henri Bergson em Matéria e Memória ${ }^{34}$, largamente utilizado pela crítica fotográfica, que nos será especialmente importante para a aproximação das obras artísticas, escrita e visual, referidas. Marca o filósofo que "as relações relativas ao sujeito e ao objeto, à sua distinção e à sua união, devem ser colocadas mais em função do

\footnotetext{
${ }^{34}$ Bergson, Henri. Matéria e Memória. São Paulo: Martins Fontes, 1999.
} 
tempo que do espaço" ${ }^{35}$. Desta forma, percebemos que o tempo é imprescindível para o discurso. Ainda que enclausurados no espaço inóspito das tumbas, em um espaço que não se modifica, os mortos de Comala gozam de resíduos de tempo com que podem murmurar suas histórias. Levantadas essas observações, podemos, portanto, deter-nos em cada uma das expressões artísticas de Rulfo e nos efeitos do tempo híbrido sobre elas.

\section{Os tempos da fotografia}

Susan Sontag afirma que as fotografias são "os mais misteriosos de todos os objetos que compõem e adensam o ambiente que identificamos como moderno"36. A palavra "mistério", antes requerida para referir-nos ao romance Pedro Páramo, permeia, também, a definição da fotografia para essa autora, que identificara Juan Rulfo como o melhor dos fotógrafos latino-americanos. Em seu ensaio sobre a fotografia, a escritora estadunidense nos faz vislumbrar a interdependência entre narrativa e tempo na fotografia: "Só o narrativo nos pode permitir compreender", afirma. A narrativa requer um tempo para se firmar, uma vez tomadas narratividade e temporalidade como possuidoras de uma “correlação primordial”37. Em concordância com sua postulação, Víctor Jiménez, crítico da obra fotográfica de Juan Rulfo, defende que, para se

\footnotetext{
${ }^{35}$ Citado por Lissovsky, Mauricio. "Introdução". In: A máquina de esperar. Origem e estética da fotografia moderna. Rio de Janeiro: Mauad X, 2008, p.12.

${ }^{36}$ Sontag, Susan. Sobre fotografia. São Paulo: Companhia das Letras, 2013, p. 14.

${ }^{37}$ Narratividade e temporalidade aqui são tomadas de acordo com as postulações de Paul Ricoeur: "considero que o caráter temporal da experiência humana é o que está em jogo especificamente nas pretensões referenciais de toda obra narrativa (...). Em outros termos, o tempo devém [do] tempo humano na medida em que é articulado de modo narrativo, e os relatos adquirem sentido ao tornarem-se as condições da existência temporal". Ricoeur, Paul. Entre tempo e narrativa: concordância/discordância. Trad. João Batista Botton. In: Revista Kriterion. [on-line]. Vol. 53. N. 125. Belo Horizonte, 2012. ISSN 0100-512X. Disponível em <http://dx.doi.org/10.1590/S0100-512X2012000100015>.
} 
compreender a fotografia, há de se imprimir a ela um discurso narrativo que é sua própria extrapolação. ${ }^{38} \mathrm{O}$ discurso, nesses termos, extrapola a fotografia enquanto matéria e denuncia a construção que lhe é imposta. O narrativo temporaliza e desnuda a fotografia, tornando-a legível. Ambos os autores concordam, portanto, que o discurso empresta à fotografia o tempo sobre o qual ele deve fundar-se, o que nos permitiria inferir que a fotografia, sem o discurso, não dispõe de um tempo próprio. Veremos a seguir que tampouco a ausência do tempo na fotografia é aceitável.

$\mathrm{Na}$ tradição fotográfica, embora muito jovem, ocorre um importante deslocamento do tempo. Antes, o lugar ocupado com centralidade pelo tempo, logo após a descoberta do daguerreotipo por Louis Daguerre e Nicéphore Niepce, dava-se justamente no momento da pose do modelo para o fotógrafo, que chegava a durar vários minutos para que a imagem fosse fixada pelas primeiras máquinas fotográficas. Acessórios para manter cabeça e outros membros do corpo imóveis foram usados na tentativa de diminuir o incômodo dos modelos e as imperfeições na foto revelada ${ }^{39}$. O consenso de que a fotografia congelava o tempo e produzia um objeto mágico, em que se podia revelar a eternidade, se opunha flagrantemente com a forma complicada com que se deram essas primeiras imagens.

\footnotetext{
${ }^{38}$ Jiménez, Victor. “São apenas imagens”. In: 100 Fotografias. São Paulo: Cosac Naif, 2010. ${ }^{39}$ Hippolyte Bayard denominou seu autorretrato tirado em 1840 de "Self-portrait as a drowned man [Autorretrato como um homem afogado]", justamente devido ao longo tempo de exposição a que teve que se submeter para a sua confecção. O resultado desse retrato é a figura de um homem aparentemente morto, apoiado em um móvel à sua esquerda, com as mãos repousando sobre o colo, o que confere comicidade àquele esforço dispendido por modelo e fotógrafo na época. Segundo Lissovsky, referente ao retrato de Bayard e ao efeito da fotografia de tornar mortos os homens vivos, fenômeno já apontado por Barthes em A Câmera Clara "a mesma imobilidade que transformava vivos em mortos também podia realizar o 'milagre' contrário. Durante os anos seguintes [a 1840], foi relativamente frequente fotografar crianças mortas como se estivessem dormindo". Lissovsky, Mauricio. Op. Cit., p.45, nota 105.
} 
Com o rápido avanço da técnica fotográfica, a imagem se despede do tempo despendido pelo modelo no momento da pose. Com um obturador cada vez mais veloz, a câmera fotográfica passa a dispor de quase completa liberdade para flagrar os instantes mais fugidios a um olhar comum. Ensaios fotográficos sobre o movimento como os de Eadweard Muybridge passam a ilustrar um passado recente, mas totalmente obsoleto. O olhar humano é desafiado pela câmera fotográfica, numa competição desigual e sem resistência deste último competidor: a vantagem do olho fotográfico é evidente. O obturador passa a figurar como uma potente arma apontada para o tempo, agora, mais do que nunca, dando-nos a impressão de poder aprisioná-lo para sempre na imagem fotográfica.

Porém, com a fotografia moderna, o tempo ganha uma nova e importante dimensão de análise. A perspectiva renascentista concebida para a pintura do Quattrocento, e posteriormente adotada pela fotografia em seus primórdios, quando ainda se via como filha aprimorada daquela arte, "espacializa" a imagem e a "destemporaliza". A perspectiva impõe, nestes termos, a localização dos objetos da imagem independentemente do tempo que os separa. Em outras palavras, era o olho singular do pintor-fotógrafo quem decidia o posicionamento dos objetos na imagem, tendo como base o triângulo formado no espaço entre o olho e as coisas vistas. Segundo Alberti, em $D a$ pintura $^{40}$, esta era a única forma de ver o espaço entre os dois pontos da orla, mais próximos e em cada lado do olho do pintor, que se aprofundavam em busca do vértice do triângulo no fundo da imagem tridimensional. Os objetos,

\footnotetext{
${ }^{40}$ Alberti, Leon Battista. Da pintura. Campinas: Editora Unicamp, 1999.
} 
portanto, tinham o seu lugar marcado nesse espaço quantitativo que se estendia conforme as medidas do triângulo formado.

A fotografia moderna, por sua vez, atua de forma oposta. Uma vez emancipada da filiação com a pintura, ocorre a "despacialização" da imagem fotográfica moderna, recobrando a presença do tempo à sua composição. Não é mais "a visão do Ciclope" 41 que impõe as posições precisas dos objetos a partir de seu único olho formando o triângulo albertiano. A fotografia moderna faz com que o fotógrafo dirija vários olhos a suas imagens, os olhos do espectador se perdem nas direções que aqueles olhos apontam, projetados por um longo tempo de estudo da imagem antes da pressão do obturador. É o tempo que age nestas imagens, com toda a sua subjetividade que lhe é inerente.

Com o advento do instantâneo, então, o tempo é rechaçado da construção da fotografia enquanto matéria, largamente disseminada como técnica $^{42}$ sob o alcance de todos, sobretudo com o advento do papel de gelatina que possibilita com que a fotografia seja amplamente reproduzida. O tempo retoma sua força de análise e o instantâneo é alvo de constantes sondagens. É dotado do recurso da apreensão das imagens em fração de segundos pelo obturador que Henri Cartier-Bresson postula suas diretrizes no texto canônico "Decisive moment", que será como a nova bíblia dos fotógrafos que o sucedem, e descreve sua relação com o tempo na fotografia.

Jean-Pierre Montier, crítico da obra de Cartier-Bresson, analisa o momento decisivo como o momento em que duas durações distintas são apreendidas pelo clique do fotógrafo e em que passado e presente se

\footnotetext{
${ }^{41}$ Machado, Arlindo. A ilusão especular. São Paulo: Brasiliense, 1984, p. 61.

${ }^{42}$ Benjamin, Walter. "A era da reprodutibilidade técnica”. In: Obras escolhidas I. Magia e técnica, arte e política. Ensaios sobre literatura e história da cultura. São Paulo: Brasiliense, 2012.
} 
apresentam como simultâneos. ${ }^{43} \mathrm{O}$ fotógrafo seria quem poderia atingir exatamente o centro do alvo em que se cristaliza essa simultaneidade. Em seu célebre texto $^{44}$, Cartier-Bresson destaca o privilégio do instante em que o fotógrafo, assim como um arqueiro-zen, dispara seu obturador contra o objeto capturando-o a partir de um impulso espiritual, ritual marcado por concentração e despojamento, e capaz de flagrar as cenas de maneira espontânea. Para assegurar essa espontaneidade, Cartier-Bresson abriu mão de outros avanços da tecnologia fotográfica, como o flash e as cores, optando por fotografias em preto e branco. Agindo dessa forma, acreditava que era possível ao fotógrafo ser honesto com sua obra e expressar de forma transcendente o acontecimento real.

O instante referido por Cartier-Bresson foi um importante tema para filósofos clássicos como Aristóteles, para quem o instante é a medida para o “antes" e o "posterior", que dariam o alcance numérico do tempo. Nesses termos, o tempo é quantidade de movimento e, de acordo com essa teoria, pode-se afirmar, então, que na imagem fotográfica não há tempo, pois o instante fotografado, retirado de uma linha consecutiva, representaria um instante ausente do tempo. Sem o "antes" e o "posterior", sem um movimento quantificável, a imagem fotográfica permaneceria destituída de tempo ${ }^{45}$.

A tradição moderna, por sua vez, sofistica esse "não tempo" do instante aristotélico. Henri Bergson, no século XX, postula que não é possível numerar o tempo como tradicionalmente estava sendo feito, pois este seria

\footnotetext{
${ }^{43}$ Montier, Jean-Pierre. Henri Cartier-Bresson and the Artless Art (World Design). Londres: Thames \& Hudson, 1996.

${ }^{44}$ Cartier-Bresson, Henri. Imagens à la sauvette (The decisive moment). Paris: Editions Verve, 1952.

${ }^{45}$ No século V, o filósofo Santo Agostinho, mencionado anteriormente, parte dessas mesmas considerações aristotélicas para a análise da problemática do tempo a que se detivera em grande parte de suas postulações nas Confissões. Santo Agostinho. Op. Cit.
} 
qualitativo e não quantitativo, segundo a percepção do homem e não segundo as leis da física que privilegiavam a quantidade. $\mathrm{O}$ homem teria a intuição da duração do tempo desdobrando-se em seu exterior. Dessa forma, o instante não pode ser o marco zero do tempo. O que ocorre, de fato, na imagem, é a atualização de um passado simultaneamente ao presente da percepção de seu receptor. O homem é capaz de perceber distintas durações simultâneas. A fotografia faz depararem-se dois momentos distintos, aquele atual de quem a observa e a reminiscência daquele momento ao qual pertencia o instante a que se refere. Não é um movimento regressivo ou progressivo que vemos na fotografia, mas um espiral que se revira sobre si mesmo sem que chegue a qualquer lugar ${ }^{46}$.

Um teórico que se aproxima dessa imagem em que o tempo na fotografia se desdobra entre presente e passado, apoiado na teoria do tempo bergsoniana e pensando a imagem cinematográfica, é Gilles Deleuze ${ }^{47}$. O filósofo conceitua o que chama de "imagem-cristal" a partir da simultaneidade de tempos ou durações. A imagem-cristal é aquela que contém essencialmente dois lados contrapostos, o claro e o opaco, solidifica o tempo e o apresenta como uma imagem-tempo fixa, em uma relação em que o movimento e o tempo se inverteram. O que antes era movimento, agora é tempo. Porém, na imagem-cristal, o tempo é falso, pois seu futuro problematiza todo o modelo formal do movimento, aquele em que o "anterior" e o "posterior" se revezam, na visão clássica, exemplificada anteriormente com Aristóteles. O que está por

\footnotetext{
${ }^{46}$ Tal fenômeno também ocorre na escrita literária, como observaremos mais adiante.

${ }^{47}$ Deleuze, Gilles. A imagem-tempo. São Paulo: Brasiliense, 2011.
} 
vir no tempo questiona o passado e o presente da imagem, ambos congelados no instante imagético ${ }^{48}$.

A partir dessa interação, pensando na intenção do fotógrafo por trás da câmera capaz de interferir nos "tempos" da imagem fotográfica e voltando-se, mais especificamente, ao instantâneo fotográfico, Maurício Lissovsky conceitua sua "máquina de esperar", que diz respeito à fabricação da imagem a partir da expectação do fotógrafo durante a sua captura, em contrapartida àquela anterior expectação do próprio modelo frente à máquina fotográfica nos primórdios da fotografia ${ }^{49}$. Em sua expectação, o fotógrafo se utiliza do zoom e delimita, na ajustagem da imagem fotográfica a se produzir, como o tempo discorrerá dentro dessa imagem ${ }^{50}$. Podemos afirmar que o espectador dessa imagem, portanto, participa de sua temporalização, compartilhando a percepção do tempo impressa pelo fotógrafo na imagem pronta.

Percebemos, portanto, que os teóricos citados levam em conta a hibridez do tempo fotográfico para compor suas postulações. E a hibridez a que se referem faz com que a fotografia se destaque de uma linha cronológica, aprisionando passado e presente e esquivando-se do futuro. Em um dos únicos momentos em que Rulfo escreve sobre a fotografia podemos notar como o

\footnotetext{
${ }^{48}$ Deleuze cita como exemplo máximo de sua teoria o filme "O Estado das Coisas" de Wim Wenders (Der Stand der Dinge, 1982). Uma trupe de atores é obrigada a interromper a gravação de um filme, pois o orçamento para sua produção se esgota. Devem, então, seguir nas intermediações da locação aguardando que o dinheiro seja obtido pelos produtores. A interrupção, a espera e a irrupção de uma metalinguagem cinematográfica faz com que Deleuze visualize a imagem-cristal: o devir dos personagens está problematizado, a espera questiona seu passado e presente.

${ }^{49}$ Lissovsky, Mauricio. "Introdução". In: A máquina de esperar. Origem e estética da fotografia moderna. Rio de Janeiro: Mauad X, 2008.

${ }^{50}$ Bergson ainda ressalta que a ajustagem do foco da câmera pelo fotógrafo se assemelha ao nosso trabalho com a memória, tentando resgatá-la da base do cone da memória para atualizá-la no vértice que converge com a linha perpendicular da realidade: "Trata-se de recuperar uma lembrança, de evocar um período de nossa história? Temos consciência de um ato sui generis pelo qual deixamos o presente para nos recolocar primeiramente no passado em geral, e depois numa certa região do passado: trabalho de tentativa, semelhante à busca do foco de uma máquina fotográfica”. Bergson, Henri. Matéria e Memória. São Paulo: Martins Fontes, 1999, p. 156.
} 
tempo cronológica, contudo, pode ser remetido pela fotografia, mas como algo fora dela mesma. $\mathrm{O}$ escrito-fotógrafo escreveu um pequeno texto sobre uma exposição de fotografias que Cartier-Bresson produziu durante uma estadia no México $^{51}$. O tempo histórico é notadamente referido por Rulfo nas fotografias do instante decisivo do francês. Nesse texto, é importante notar que, quando um espectador como Juan Rulfo temporaliza a fotografia no sentido de revelar seu passado, ele não a assemelha a um documento histórico, mesmo porque o que lhe salta à vista não é aquele momento petrificado nos enquadramentos da imagem, mas o que, de certa forma, escapa à imagem. A relação direta da fotografia com o tempo cronológico não existe, igualmente ao que ocorre no romance Pedro Páramo. Recompor um marco na linha sucessiva do tempo para a imagem fotográfica seria o mesmo que reconstruir a história extraliterária que rodearia o romance. Agindo dessa forma, estaríamos eliminando a problemática que o próprio tempo inscreve na imagem fotográfica. Apesar de a fotografia causar a nítida sensação de resgate do passado, o passado enquanto tal não se apresenta na imagem fotografada. $\mathrm{O}$ historiador François Simiand afirmou que o passado não é uma fotografia. ${ }^{52}$ Afirmamos aqui o caminho reverso, a fotografia não é o passado.

A fotografia enlaça um instante da vida e o eterniza enquanto objeto, porém, esse objeto é essencialmente diferente daqueles presentes no mundo sensível do real. Não compartilhamos, em uma foto, o tempo do acontecimento fotografado, tampouco a precisão do objeto, homem ou paisagem apreendido

\footnotetext{
${ }^{51} \mathrm{O}$ texto será novamente referido no terceiro capítulo da dissertação com mais atenção.

${ }^{52}$ Simiand, François. Método Histórico e Ciência Social. Bauru: Edusc, 2003.
} 
ali $^{53}$. A fotografia apresenta tempos híbridos que emanam de cada um de seus objetos e se confrontam na imagem.

Sobre esses tempos divergentes presentes na fotografia, como erigir um discurso? A própria descrição das fotografias feita nesse trabalho deve ser questionada, nesses termos. Ao olharmos a imagem percebemos a diferença de temporalidades mescladas, mas ao narrá-las, ao discursivizá-las, alcançamos um tempo que é exterior a elas. Foi nesse tempo que Rulfo se apoiou para descrever a foto de Cartier-Bresson. O tempo apreendido na fotografia é inarrável, é silencioso. Os segundos que os olhos levam para alcançar todos os objetos, para intuir todas as suas relações assemelha-se em qualidade ao tempo da expectação do fotógrafo. Demonstra o aspecto que o tempo marcou nesses objetos, mas esse aspecto não pode ser expresso através do discurso, que o desmente com o forjamento de um tempo outro, próprio do discurso que é excedente à imagem fotográfica. Mesmo assim, ainda que não possa ser "discursivizado", o compartilhamento desse tempo entre fotógrafo e observador é realizado através da imagem.

\section{Os tempos da fotografia de Juan Rulfo}

Juan Rulfo compôs suas fotografias armado com uma Rolleiflex, câmera fotográfica composta por duas lentes, o que obrigava o fotógrafo a observar a lente para o enquadramento a partir da superfície da máquina,

\footnotetext{
${ }^{53}$ Para Roland Barthes, em A câmera clara, o que vemos numa fotografia é o "spectrum" da coisa fotografada, e não o próprio objeto real. Este "spectrum" se revela pelo fato de apresentar uma disposição do objeto fotografado que jamais se repetirá, tanto pelas intenções do ser fotografado, do próprio fotógrafo ou das condições externas a estes atores do ato fotográfico que lhes impõe certas posições. Barthes comenta, por exemplo, no caso dos retratos de família, sobre as roupas e a posição de cada membro no retrato. Posição social, contexto histórico, enfim, fatos exteriores ao objeto da fotografia, atuam para impor certas atitudes e poses aos fotografados e para impor certa perspectiva ao olhar do fotógrafo. Barthes, Roland. Op. Cit..
} 
apoiando-a na altura do abdômen para que a segunda lente, frontal, pudesse capturar a imagem. Desta forma, o escritor adentra o campo de discussão acerca do tempo pela imagem visual.

Os temas de suas fotos são semelhantes àqueles presentes em sua obra narrativa: o interior mexicano, os indígenas e os campesinos, as paisagens desoladas e desérticas, ruínas do passado indígena e presença ostensiva da cultura espanhola. Suas fotografias também dialogam em tema com as fotografias de grande parte dos fotógrafos mexicanos da época que se debruçaram na busca da "mexicanidad", como Nacho López, importante fotojornalista e amigo de Rulfo. A exemplo de Cartier-Bresson, esses fotógrafos privilegiaram o preto e branco em busca de maior autenticidade às suas fotos e deram continuidade à tradição fotográfica que se instalara no país apenas seis meses após o surgimento do daguerreotipo na Europa.

A busca da figura representativa do México no momento da pósrevolução foi marcada pela procura de unidade em um México muito diverso e foi assumida por parte da produção cultural e artística do país, entre a qual figurava a fotografia mexicana do período. O "pintorequismo" seguido por certa fotografia e cinema mexicanos buscava situar um lugar cômodo ao indígena e ao campesino, que poderiam conviver harmoniosamente com o “presidencialismo", marcado pela figura intocável dos ícones políticos ${ }^{54}$; dessa forma, comungava-se a figura do patriarca mexicano com a do indígena e

54 "Carlos Monsiváis se refirió así al espiritu de esa época: "Nada de 'país plural'o de 'diversidad cultural', México es uno”. Los medios de comunicación masivos representaban esa unidad como presidencialismo y pintorequismo: los primeros vueltos iconos (e intocables), los segundos vueltos exóticos (y seguros). Fotógrafos como Enrique Díaz, Luis Márquez y Hugo Brehme cristalizaron la mexicanidad en el rostro del gran patriarca y en la figura anónima del indígena/campesino sonriente/sufriente de las revistas ilustradas, y cineastas como Emilio Fernández y Gabriel Figueroa los llevaron a la pantalla".Mraz, John. "Nacho López y la mexicanidad". In: Revista Lunea Cornea [on-line]. N. 31: Cidade do México, 2007, p. 165. Disponível em <http://issuu.com/c_imagen/docs/lunacornea_31>. 
campesino a fim de criar uma unidade ideológica harmônica no país na pós Revolução Mexicana ${ }^{55}$. Nacho López, Manuel Álvarez Bravo, Juan Rulfo e outros de seus contemporâneos miraram suas lentes contra retratos mais complexos, apresentando o indígena marginalizado (Nacho López, no Distrito Federal) e explorado (Juan Rulfo, em Oaxaca) e reconfigurando a imagem do mexicano frente à modernidade, bem como à própria história do país.

A fotografia de um campesino lendo, de Nacho López, demonstra a forma como o olhar do fotógrafo recai sobre a realidade do país. A julgar pela pose que o homem faz perante a câmera bastante próxima, trata-se de uma fotografia ensaiada, característica que foge sobremaneira às diretrizes do fotojornalismo. O homem, sentado num degrau próximo a um muro desgastado atém-se, com deleite, a uma folha de jornal rasgada. As novidades que se aceleram no país com o intento de modernização, noticiadas pelos jornais, contrapõem-se com a figura do campesino, numa ironia marcada não apenas pelo diálogo desses objetos, mas pela pose que o campesino empresta a seu fotógrafo $^{56}$.

\footnotetext{
${ }^{55}$ Julgamos impossível incluir uma breve nota com o resumo do que foi a Revolução Mexicana e os anos que a procederam por se tratar de momentos únicos na história daquele país sobre os quais recaem diversas interpretações de historiadores empenhados em seu estudo até os dias de hoje. Para uma sucinta apresentação da Revolução Mexicana, recomendamos a leitura do capítulo IX La revolución, do livro México: una breve historia del mundo indígena al siglo XX de Alicia Hernández Cháves. No mesmo livro, em capítulo referente ao primeiro decênio após a Revolução Mexicana, a autora aponta o esforço realizado pelo então presidente Plutarco Elías Calles para a institucionalização da política com forte viés "anti-caudillista", o que reafirma a busca de manter um país harmônico na época em questão. Chávez, Alicia Hernández. "IX - La revolución". In: México: una breve historia del mundo indígena al siglo XX. México DF: Fondo de Cultura Económica, 2002, pp. 302-349 e p. 366.

${ }^{56}$ Esta fotografia faz parte de uma série de outras fotografias em que Nacho López flagra - ou ensaia poses de pessoas lendo, em um diálogo direto com a série On Reading do fotógrafo húngaro Andrés Kertész, quem fotografou pessoas no ato de leitura em diversas cidades a que viajou ao longo de sua vida (1894-1985). De certa forma, López, ao dialogar com o tema de Kertész destaca o que seria o ato de leitura do mexicano, justamente na época em que a "mexicanidad" está em questão, além de oferecer um olhar sobre a assimilação da cultura ocidental por um país de base indígena, nos moldes da transculturação apontada por Ángel Rama.
} 


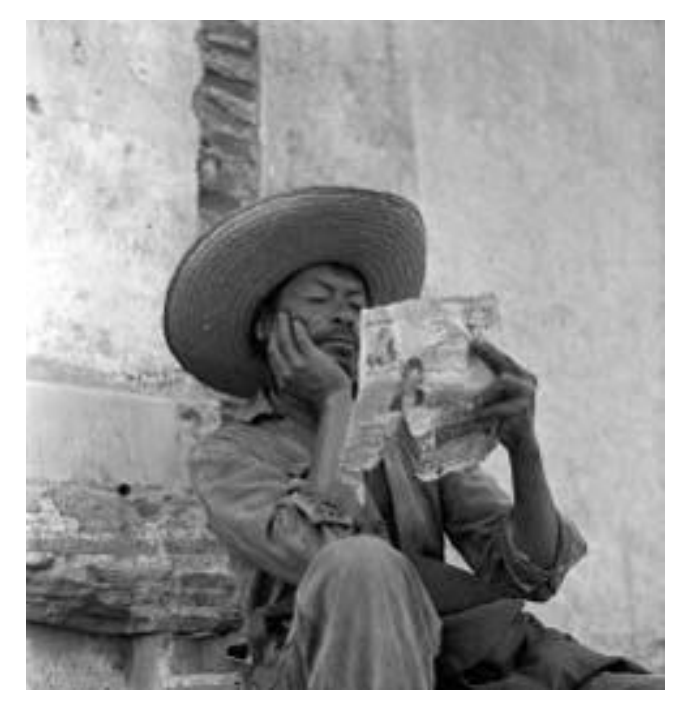

Figura 1 - Nacho López, Campesino leyendo, 1949.

A harmonia apontada pelos "pintoresquistas" não se vê nas fotografias de Nacho López, tampouco nas de Juan Rulfo quando retrata o homem mexicano e as paisagens interioranas de seu país. Além de tornar a imagem do mexicano mais complexa, Rulfo e grande parte de seus contemporâneos adotam a fotografia que volta um olhar artístico para o objeto fotografado, não se limitando a uma mera documentação do México enquanto objeto visual, e imprimindo à imagem a expectação fruto da busca pelo objeto fotografável no momento da construção da imagem fotográfica, como apontado no estudo citado de Lissovsky ${ }^{57}$.

Em uma de suas fotografias, Rulfo centra na objetiva o templo de Sanctorum, localizado no Distrito Federal. Focaliza o seu portal adornado de temas barrocos - ramos, vinhas de uvas, raízes serpenteantes - deixando implícito o resto da construção do templo como em uma metonímia. Deste portal sai, meio na sombra, meio na luz, um homem com chapéu na mão. Ao

\footnotetext{
57 Alberto Vital, no libro Rilke, Rulfo menciona que o filho de Juan Rulfo, Juan Carlos Rulfo, "testimonia de primera mano que su padre podía tardarse dos o tres días en estar satisfecho con un objeto, un ángulo, un enfoque, antes del clic definitivo". In: Vital, Alberto. Rilke, Rulfo. México D.F.: Samsara, 2012, p. 35.
} 
passo que o portal do templo se revela iluminado e centralizado, o homem que o cruza disfruta de penumbra, sua figura mal se vê, deslocada para o canto esquerdo da foto. A luz, que vem da direita para a esquerda, impõe escuridão ao interior da igreja, a partir da perspectiva daquele que a olha de frente. $\mathrm{O}$ homem é fotografado justamente no momento em que seu corpo é disputado pela escuridão que o antecede e pela luz que o antecipa. Há, nesta fotografia, um jogo paradoxal entre claro/escuro, humano/divino (o homem frente ao templo religioso).

A divisão, o lado escuro e o lado luminoso presentes na foto nos permite a aproximação à teoria de Deleuze ${ }^{58}$ o homem com o chapéu na mão saindo do templo de Sanctorum se enquadra na imagem cristal. Sua figura é emblemática em relação aos tempos simultâneos na fotografia, uma vez que o tempo passado pode ser visto como escurecido pelo interior do templo às suas costas e o devir que se impõe a sua frente, iluminado, segue aguardando eternamente que seu caminhar prossiga, o homem se iluminaria caso seguisse caminho.

\footnotetext{
${ }^{58}$ Deleuze, Gilles. Op. Cit.
} 


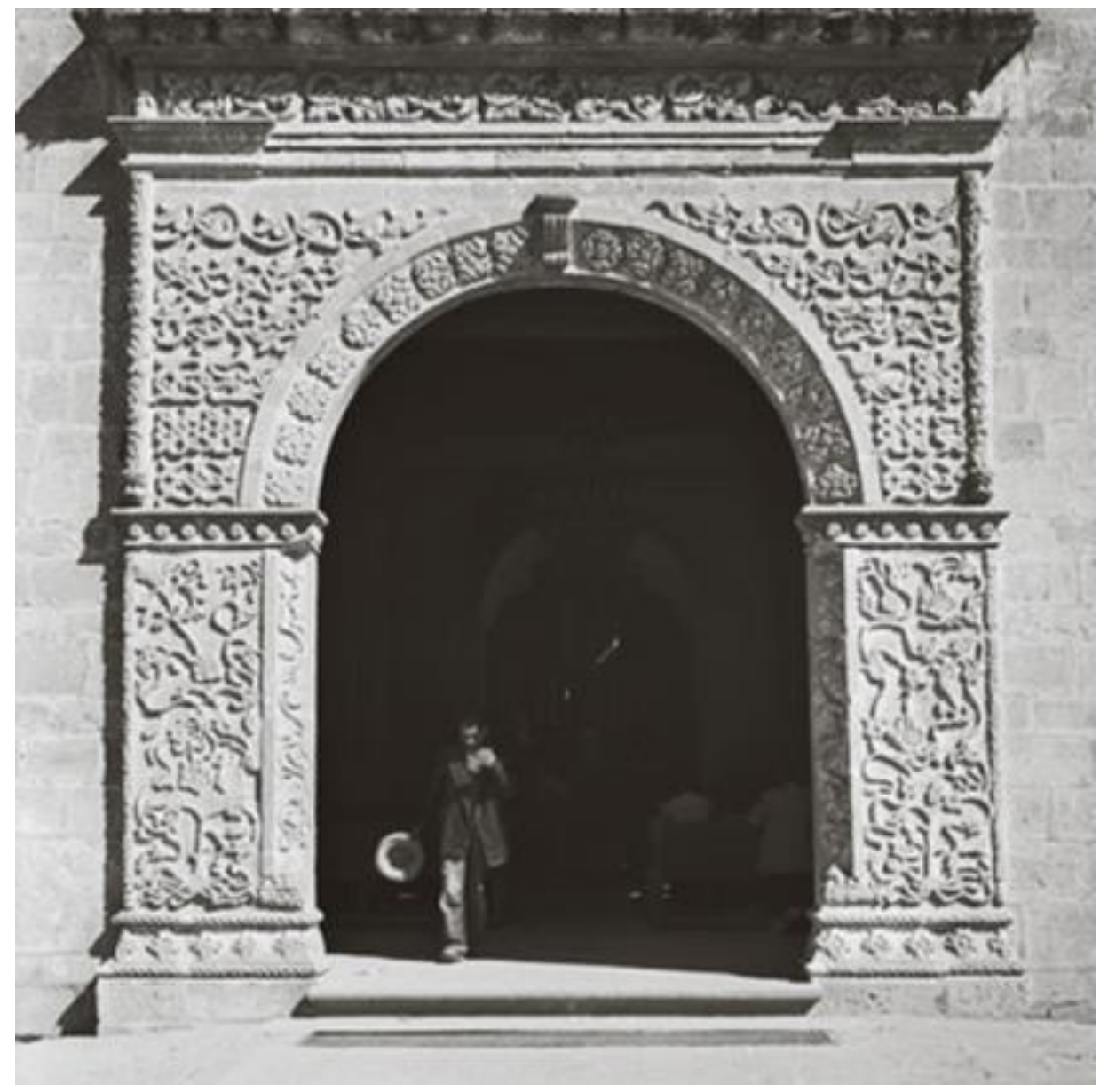

Figura 2 -Juan Rulfo, Templo de Sanctorum, 194-.

A imagem deste homem interrompido em seu caminhar nos leva a visualizar algo do clique instantâneo de Cartier-Bresson. Contudo, a posição do fotógrafo indica que a câmera não se voltou abruptamente para aquele instante que passava a sua frente, mas, muito possivelmente, estava posicionada em frente ao pórtico do templo de Sanctorum por bastante tempo, enquanto o fotógrafo Juan Rulfo ajustava a sua imagem. É com essa atitude que a modernidade e o passado se encontram nas imagens de Rulfo. A efemeridade de um movimento interrompido pela câmera se contrapõe à construção de pedras atrás do personagem que aponta para o passado. A imagem desse homem surpreendido em meio a um caminhar incompleto lembra-nos do 
personagem Luis da Silva do romance Angústia do brasileiro Graciliano $\operatorname{Ramos}^{59}$, quando aquele vê a si mesmo em sua memória como um homem fotografado: '[t]enho a impressão de que uma objetiva me pegou, num instantâneo. Ficarei assim, com a perna erguida, a pasta debaixo do braço, o chapéu embicado" 60 . Além da descrição de um homem flagrado em meio a seu caminhar, é importante frisar em que pensava esse homem, informação só possível através da narrativa literária: "Luis da Silva, a caminho da repartição, lesando, pensando em defuntos"61. Mesmo quando "mostra" ao leitor uma fotografia, a narrativa revela seu poder de inferir até mesmo no pensamento do personagem fotografado, o que de certa forma, dialoga também com o caráter ficcional da imagem fotográfica. A morte também aparece no pensamento desse personagem, assim como surge da sua condição de ser um objeto morto aprisionado na imagem fotográfica. Não é forçoso dizer que, nessa série de homens flagrados em uma trajetória fatal, podemos também incluir Juan Preciado que tem sua viagem interrompida pela morte que emana de seu passado e que o aprisiona em Comala.

O chapéu na mão do homem fotografado no templo de Sanctorum pode ser referido como uma alusão ao respeito que sente frente ao domínio religioso. Respeito este que também pode remitir ao gesto espiritual evocado por Cartier-Breson ao se referir ao "momento decisivo" em que o fotógrafo/arqueiro zen aprisiona "os anjos do tempo" ${ }^{62}$ com o clique de sua câmera. $\mathrm{O}$ aludido respeito daquele homem com chapéu na mão casa-se, numa

\footnotetext{
${ }^{59}$ Ramos, Graciliano. Angústia. Editora Record: São Paulo, Rio de Janeiro, 2012.

${ }^{60}$ Ibidem, p. 27.

${ }^{61}$ Idem.

${ }^{62}$ Lissovsky, referindo-se a Henri Lartigue, aponta o trabalho do fotógrafo que busca suas imagens em momentos fugidios como o responsável por "revelar no interstício dos instantes, os anjos do tempo". Lissovsky, Maurício. "Quantos anjos cabem em uma fotografia?". Revista Icônica [on-line]. 18/06/2013. Disponível em < http://iconica.com.br/blog/?p=5095>.
} 
leitura impregnada por esta ideia, com o respeito ao instante sagrado. As sombras dentro do templo dialogam ainda com o mistério cultuado pela igreja católica. O homem reverencia o mistério sagrado representado tanto pelo poder religioso, como pelo mistério do instante que o envolve, instante da mescla de tempos que buscamos analisar em nossa reflexão. Trata-se, de qualquer forma, da apreensão por Rulfo de um instante fatídico, revelando a perda de algo que jamais se repetirá, e em que se mesclam distintas temporalidades em uma mesma imagem.

O fotógrafo demonstra sua grande preocupação com a temática do tempo, principalmente ao nos apresentar um "par" para esta fotografia. No livro México: Juan Rulfo fotógrafo ${ }^{63}$, encontramos a fotografia de um homem entrando no Templo Sanctorum, que, como na fotografia de Cartier-Bresson, está de costas para o fotógrafo. Desta vez, o fotógrafo se posiciona mais à esquerda da entrada do templo, e o homem que entra está quase totalmente iluminado pela luz externa, enquanto sua sombra se projeta, abrasiva, contra a forte luminosidade do dia na lateral esquerda da entrada que antecede a completa escuridão do interior da igreja. De certa forma, esta sombra antecipa o que o consumiria no interior da construção. Não se trata do mesmo homem que vimos saindo do templo, e podemos supô-lo devido ao chapéu que este último traz nas mãos que tem suas abas mais largas do que aquelas do primeiro homem (primeiro em nosso discurso, pois não sabemos qual a sequência da tomada das fotos). Tampouco o templo Sanctorum é o mesmo nas duas fotografias, pois em cada uma delas está submetido a diferentes instantes que

\footnotetext{
${ }^{63}$ Rulfo, Juan. México: Juan Rulfo fotógrafo. Op. Cit.
} 
alteram sua qualidade, fato acentuado pelas diferentes posições do fotógrafo e pelas luzes e sombras que se modificam, ainda que ligeiramente.

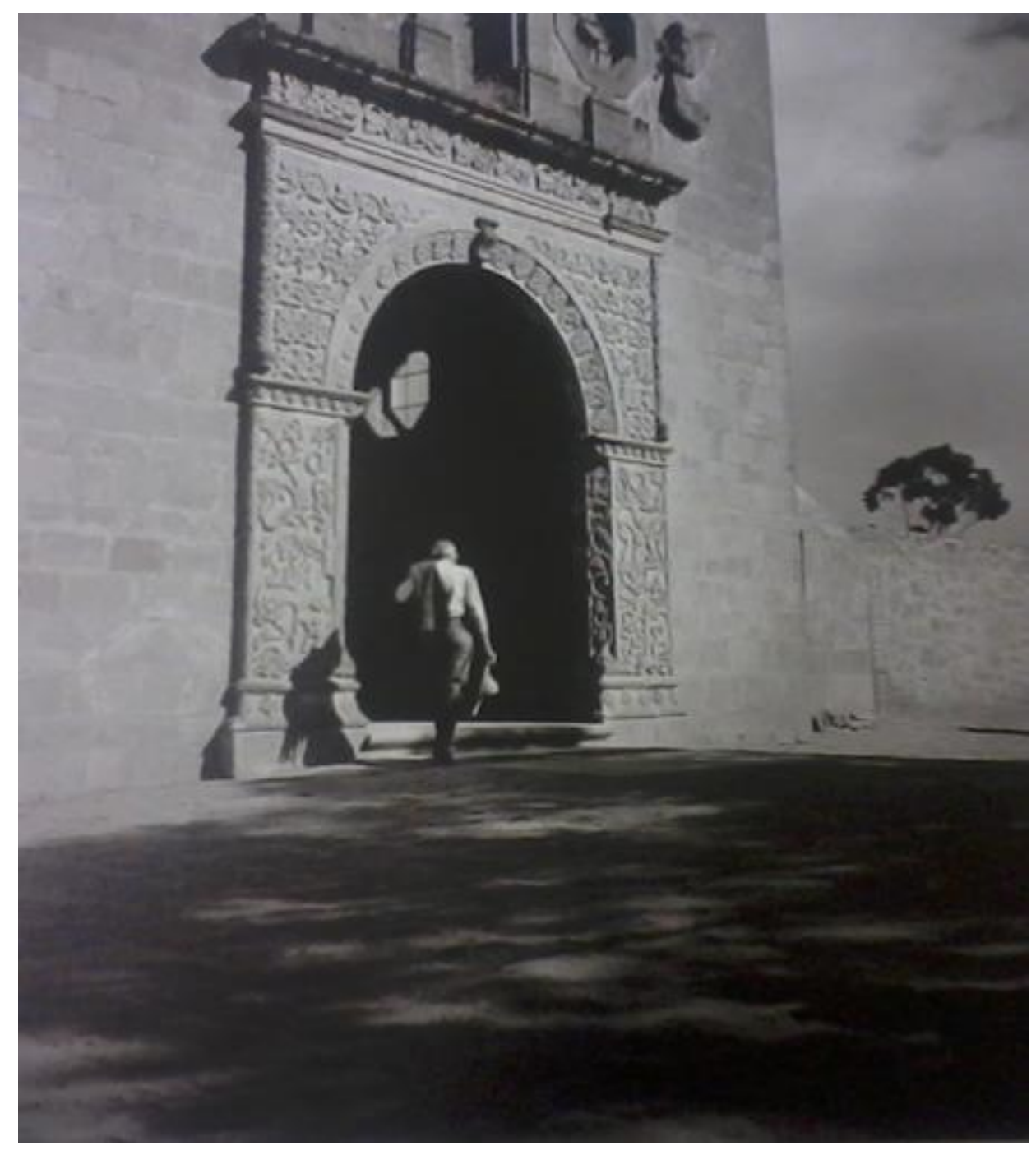

Figura 3 - Juan Rulfo, Templo de Sanctorum, s/d.

O único elemento que se faz onipresente nestas imagens é a ação do tempo. A entrada e a saída marcam duas ações que semanticamente são opostas entre si, porém estes dois contrapontos nos revelam as semelhanças entre as fotografias. Em ambas, o jogo de luz e sombra revela o jogo com o próprio 
tempo ${ }^{64}$. O homem que está saindo do templo, em comparação ao homem que está entrando, revela o seu passado e o seu possível devir. Ele já provara da luz de fora, compartilhada pelos que entram como nos mostra a segunda fotografia. No momento da saída, segue provando a escuridão do interior do templo, seu passado, e aponta a iminência do retorno àquela luz, seu devir. A iminência deste retorno demonstra que seu corpo se iluminaria completamente pelas luzes do devir que brinda a paisagem, como é o caso do homem entrando no templo. O regresso, porém, em toda a obra de Juan Rulfo, nunca se conclui e esse par de fotografias marca visualmente esta impossibilidade. O desejo do retorno se debate na clausura do futuro do pretérito.

A sombra do homem entrando, por sua vez, antecipa-se a ele no contato com o templo. O homem o penetra apenas a partir desta sombra, sua presença material no templo não se concretiza. Caso entrasse de fato no templo, se consumiria em sombra e seus contornos se borrariam na escuridão do interior da construção, como se sua presença no mistério religioso só fosse possível caso se deixasse diluir em sombra. Nestes termos, este homem é extremamente moderno, tendo seu caminho passado ofuscado pela luz externa, cindido pelo mistério da sombra e pela luz ofuscante e apanhado em seu caminhar pelos tempos híbridos que o envolvem.

Aproximando-nos do "spectrum" barthesiano ${ }^{65}$, o homem da foto não é somente o "spectrum" de si mesmo, mas também da ação que não se conclui. Descrevemos as fotografias como as de um homem saindo e entrando no templo Sanctorum. Estas ações marcadas pelo gerúndio, como no paradoxo de

\footnotetext{
${ }^{64}$ Uma vez no México, percebe-se como a forte luz do sol impõe imensas sombras contíguas às grandes construções religiosas que se espalham pelo país, construindo naturalmente esse cenário de luz e sombra tão bem aproveitado nas fotografias rulfianas.

${ }^{65}$ Barthes, Roland. Op. Cit.
} 
Zeno da corrida de Aquiles com a tartaruga, nunca vão terminar de tentar realizarem-se. A luz e o templo seguirão inacessíveis aos homens fotografados, ainda que o primeiro disfrute de alguma luz em seu corpo cindido entre luz e sombra, e ainda que o segundo tenha sua própria sombra descolada de seu corpo e agarrada às paredes do templo.

O tempo verbal empregado para a descrição da mescla de tempos nessas imagens de forma alguma descreve objetivamente a maneira como o tempo escorre pelos objetos apreendidos ali, mas nos mune de ferramentas para alocar o olhar que se aprofunda nas sombras e recorre às luzes sem deter-se em nenhum dos dois polos, rebatendo nos objetos pousados pelo fotógrafo no momento do enquadramento e compartilhando, silenciosamente, com a observação de sua expectação.

Outro par de fotos que também nos chama atenção é aquele em que uma mesma casa campesina é flagrada por Rulfo em dois diferentes momentos. Neste caso, o fotógrafo se posiciona aproximadamente no mesmo lugar nas duas fotos para seu enquadramento. Em uma delas, aproxima-se ligeiramente da casa em comparação a outra. Notamos, também, que cada uma das fotos foi realizada em diferentes momentos do dia pela posição da luz e das sombras, diferente do "par" do templo Sanctorum que, a julgar pela força da luminosidade e pela persistência das sombras inacessíveis, foram tiradas mais ou menos no mesmo período.

Na primeira destas fotos, percebemos a luz vinda do leste, à direita, parcialmente retida por uma muralha em ruínas junto ao fotógrafo. Posicionado neste ambiente entre sombra e luz, o fotógrafo mira para a pequena casa que, junto à muralha, que forma consigo um ângulo agudo, inicia uma perpendicular 
onde se alinha uma frondosa árvore. A casa e a árvore estão quase completamente saudadas pela luz do dia, as sombras que se formam na árvore apenas realçam seus detalhes e apontam a direção em que a luz é recebida.

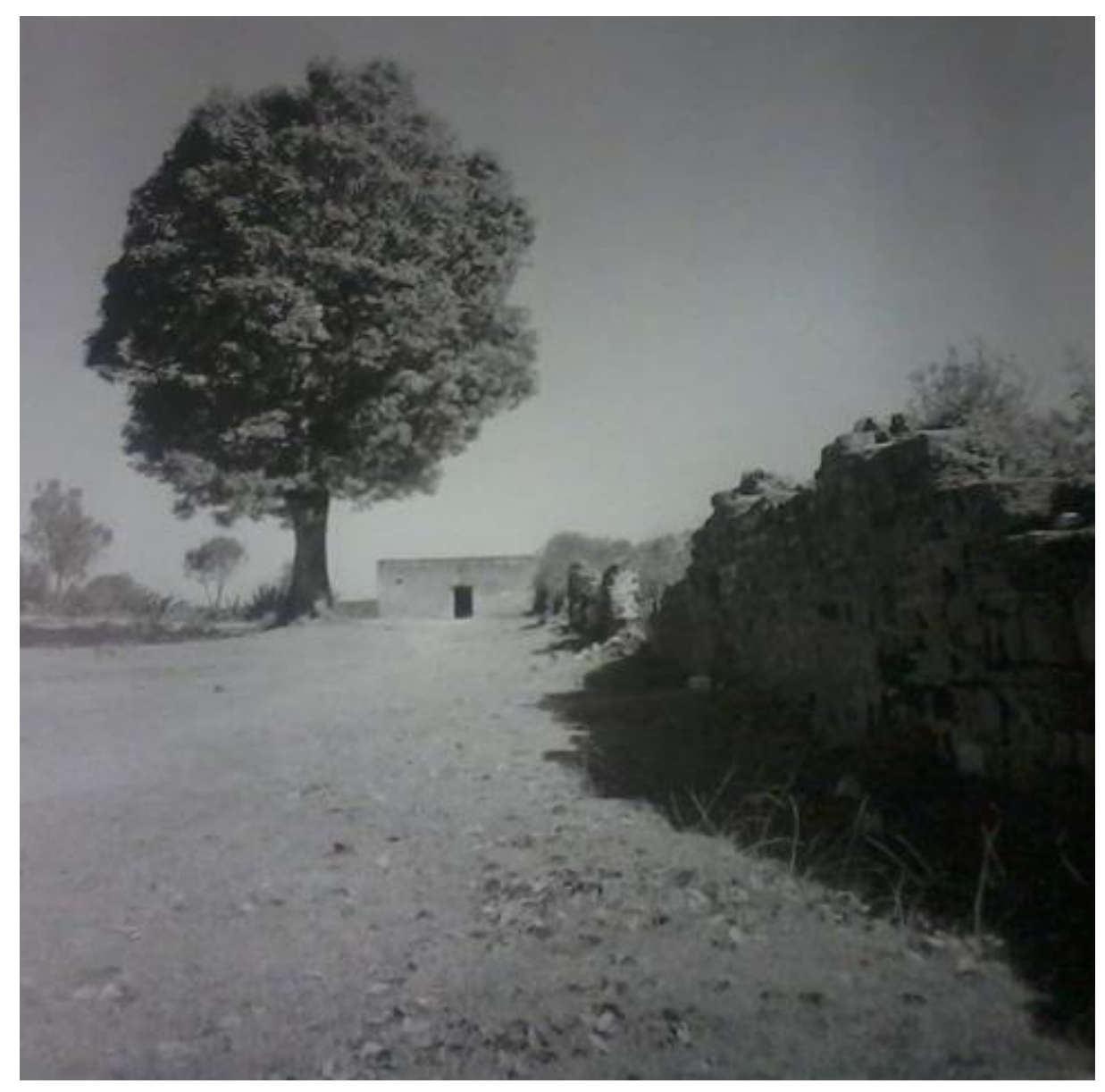

Figura 4 - Juan Rulfo, Casa campesina, s/d.

Na segunda foto, com o fotógrafo ainda junto à muralha, percebe-se a luz vinda do oeste, pondo-se à esquerda de Rulfo, quem agora deslumbra uma árvore encoberta pelas sombras. A árvore, neste outro instante, aparece com menos vivacidade, algumas folhas lhe faltam à sua esquerda, o que nos leva a pensar que provavelmente as fotos diferem, também, nas épocas do ano em que 
foram tiradas. A casa, porém, permanece igual em sua brancura e simplicidade iniciais.

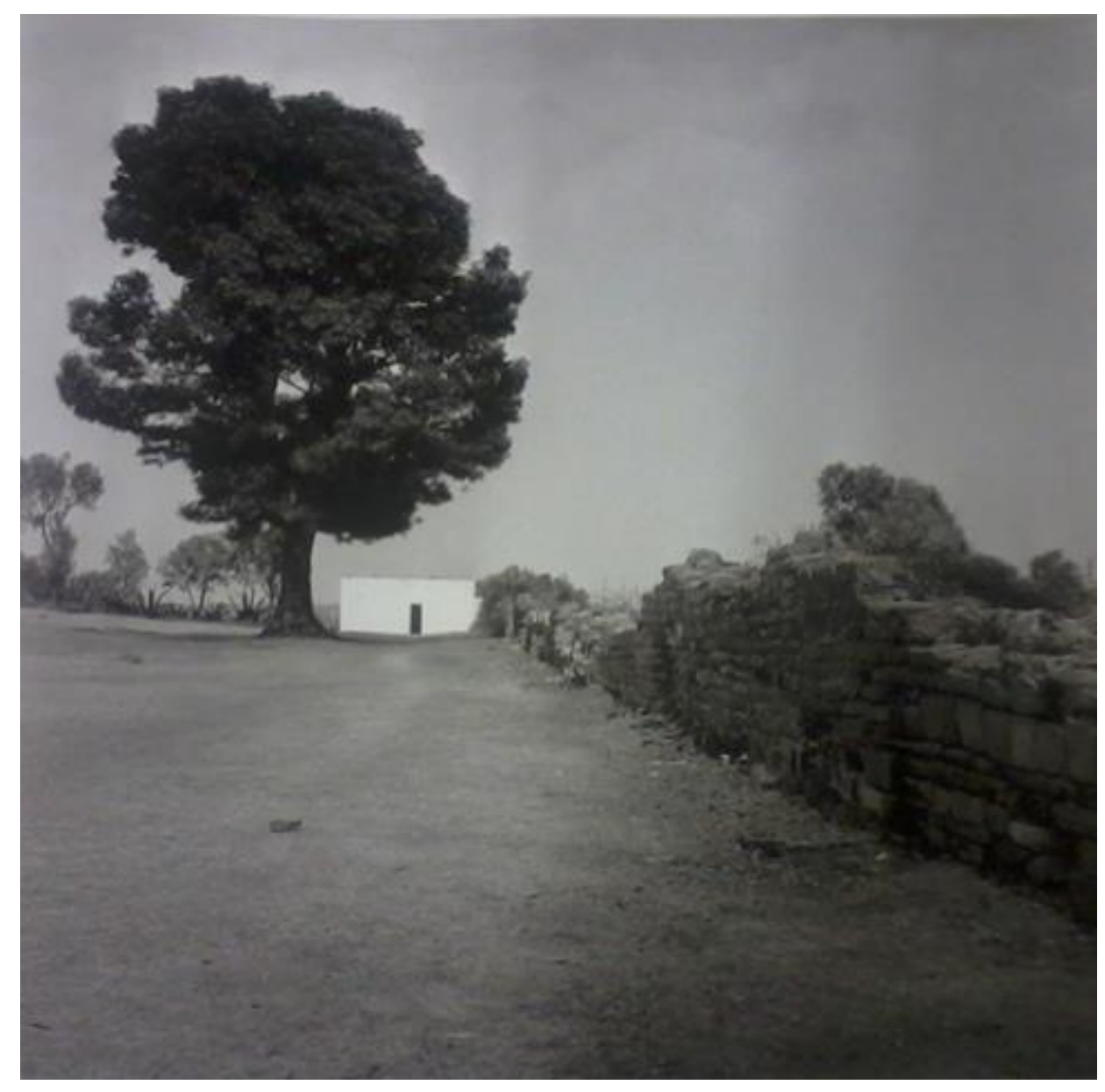

Figura 5 -Juan Rulfo, Casa campesina, s/d.

O jogo, desta vez, se faz com as consequências do tempo que, ainda que inapreensível, deixa suas marcas evidentes na paisagem. As diferentes posições da luz e da sombra que deslizam pela paisagem e a variação do rigor das folhas da árvore ao lado da casa demonstram a ação do tempo sobre as coisas do mundo. A muralha em ruínas comprova um tempo ainda mais longo, que age por um período maior do que aquele que fez com que as folhas da árvore caíssem e daquele que faz variar a posição de luz e sombra. Revelam-se, 
desta forma, diferentes tempos atuantes na mesma fotografia, mais uma vez, mas de forma distinta à daquele par anterior. Luz e sombra, folhas e muro, neste caso, são as unidades de referência que servem para nós para a percepção da passagem do tempo. Assim como as traças no conto machadiano, o muro envelhecido nas fotos da casa campesina e as ruínas presentes em tantas outras fotografias de Rulfo associam a percepção do tempo ao tempo físico que possibilita estes processos sobre a matéria. A própria fotografia que se realiza a partir de processos químicos e físicos se insere na tríade proposta por Elias para a percepção do tempo. Saltamos das considerações de Bergson, portanto, para quem o tempo físico era desnecessário para a intuição do tempo pelo homem, para casar todos estas concepções do tempo em nossas observações.

Se antes imprimimos à fotografia um discurso repleto de tempos verbais distintos, desta vez, a simples observação dos objetos das duas fotografias marca a mescla dos tempos a que estão submetidas. A posição das luzes e das sombras e a falta de folhas na árvore são, por um lado, os dados que nos permitem alocar cada foto em um tempo distinto e marcam a diferença do tempo da natureza em cada uma delas. Por outro lado, a presença do muro nas duas fotos, solene junto ao fotógrafo, marca a presença do tempo da ruína, um tempo que é o mesmo em ambas as fotos, já que o muro aparece sem modificações visíveis. Ou seja, enquanto que a falta de folhas e as diferentes posições de sombra e luz marcam, nas fotos, diferentes tempos, o muro não se modifica no par de fotos, mas sua própria condição deteriorada revela que o tempo também o alterou em outra duração. Deste modo, percebemos a simultaneidade do tempo da natureza, visível ao olho nu com o tempo da ruína, mais longo, percebido apenas pela sugestão levantada pelo muro gasto. 
A queda das folhas da árvore ainda pode levar-nos a remeter à iminência da morte aludida neste par de fotografias. A imagem da árvore nas sombras, e sem parte de suas folhas, evoca a representação das árvores postas por Deus no Jardim do Éden, segundo a tradição judaico-cristã, fortemente presente na cosmovisão de Rulfo e do México como um todo, que guardam em seus frutos a morte daquele que deles provar ${ }^{66}$.

A discussão da fotografia pelos seus pensadores tem marcado com veemência a questão do tempo como um dos seus grandes pilares problemáticos. Ademais de seu caráter documental ou mimético da realidade, apresentado por um discurso menos atento ou com fins mais imediatos, como no caso do jornalismo, advém a observação da fotografia enquanto um objeto que suscita reflexão e apreciação, um objeto artístico. Juan Rulfo entende bem essa potência problemática da fotografia e o demonstra com suas próprias imagens em cuja composição tece as linhas de diálogo com os debates sobre o conceito do tempo. Munindo-se do aparato fotográfico cruza, portanto, sua própria preocupação com o conceito do tempo com a problemática levantada a este respeito pelos pensadores da ação da máquina fotográfica e de seu produto, a imagem fotográfica.

\section{Pedro Páramo e a fotografia: possibilidades da expressão do tempo?}

\footnotetext{
${ }^{66}$ A Árvore da Vida e a Árvore do Conhecimento do Bem e do Mal são mencionadas na Bíblia hebraica. A primeira se localiza ao centro do Jardim do Éden e Deus nega seu acesso a Adão e Eva, após o primeiro casal humano ter provado do fruto da Árvore do Conhecimento do Bem e do Mal, condenando-os à mortalidade. "Eis que o homem tornou-se como um de nós pelo conhecimento do que seja bem ou mal. Agora que ele não estenda a mão para colher também da árvore da vida, dela comer e viver para sempre!". Gênesis, 3, 20. As moléstias da terra e a dor do parto, além da expulsão do Jardim do Éden, são as demais punições que sofre o casal devido à sua desobediência.
} 
Observando as especificidades do tempo na narrativa, vemos este elemento como fundador por excelência do romance. Tempo, espaço e ação são os pilares recorrentes sobre os quais as obras literárias se apoiam para postularem até mesmo suas "rupturas". Marcel Proust com Em busca do tempo perdido $^{67}$ põe em cena um tempo exterior ao homem. Pequenas motivações externas como cheiros, sabores, visões podem reservar a experiência de diferentes tempos da memória e a consequente construção de um discurso apoiado neles. Novamente, podemos atribuir a estes fenômenos a qualidade de unidades de tempo que possibilitam ao homem a compreensão da passagem do tempo.

Como já foi observado pela vasta fortuna crítica do único romance de Juan Rulfo, sua narrativa recorre a procedimentos distintos daqueles utilizados por seus predecessores para compor a história. Como também já exaustivamente mencionado, causa certa ruptura em relação ao "romance da Revolução" que se "engajava" em buscar estruturas narrativas que, ao ver dos seus autores, respondessem com mais proximidade à realidade. Talvez nos seja válido, contudo, relativizar esta proximidade, uma vez que o tempo cronológico dessas narrativas também é construído de forma diferente daquele vivido na realidade.

O "romance da Revolução", como qualquer narrativa que busca "seguir" o tempo cronológico, impõe ao tempo narrativo prolongamentos e saltos que convêm ao autor para a busca daquela aproximação com a realidade. Nestes termos, apesar de tomarem vias distintas, realizam, como Rulfo, uma cuidadosa construção do tempo narrativo. O que caracteriza a efetiva diferença

\footnotetext{
${ }^{67}$ Proust, Marcel. Em busca do tempo perdido. Rio de Janeiro: Zahar, 2003.
} 
em relação ao tempo cronológico buscado pelos romances realistas e o tempo dos mortos em Pedro Páramo é a forma como a referência ao tempo se dispõe, como os personagens dos romances entram em acordo com a arbitrariedade deste tempo e como estes personagens identificam aqueles tempos divergentes individualmente. Estes pontos não são de grande interesse dos autores realistas, mexicanos ou não, pois erigem em suas narrativas um ambiente em que o tempo, ainda que salte ou se detenha em determinado evento, à revelia do tempo na realidade, parece oferecer a todos os seus personagens um código facilmente decifrável e compartilhável. O tempo nessas narrativas emula um relógio com intervalos desiguais entre as horas, mas sem que causem sobressaltos àqueles que se organizam ao redor delas.

Em Pedro Páramo, a narrativa é construída de tal forma que se chega a vislumbrar a completa ausência do tempo, como afirmado por grande parte de sua crítica. Isso se dá pela falta de um espaço temporal conforme os moldes tradicionais da narrativa, onde ocorre a construção do discurso. A consciência dos personagens, que é a responsável por grande parte da narrativa, se revela destituída do corpo que lhe daria o movimento, a linearidade e um discurso sólido. Segundo Derrida, “(...) a escrita é um corpo que só se exprime (...) se o seu espaço for temporalizado" ${ }^{68}$. Ou seja, o espaço fornece o marco temporal para que o discurso se apoie e se desenvolva. Com esta afirmação retomamos dois aspectos já levantados anteriormente: o tempo funda o discurso e, sem um tempo claramente definido, o discurso é problematizado. No caso da fotografia, utilizamos tempos verbais para o forjamento de um discurso que possa apreendê-la e descrevemos imagens que remetem a diferentes tempos sobre os

${ }^{68}$ In: Derrida, Jacques. "Cap VI. A voz que guarda silêncio". In: A voz e o fenômeno. Introdução ao problema do signo na fenomenologia de Husserl. Lisboa: Edições 70, 1996. 
quais, novamente, nosso discurso pode se debruçar. No romance de Rulfo, alheio a um tempo definido, uma vez que trata do tempo dos mortos, o discurso se funda de maneira problematizada. Para possibilitar a construção do corpo da escrita, Rulfo impõe à sua narrativa diversas estratégias que permitirão com que o discurso remita a distintos tempos simultâneos.

No texto "Tiempo y Eternidad", a noção de tempo identificada por Violeta Peralta ${ }^{69}$ é construída a partir das considerações de Bergson. Levando em conta o que afirma o filósofo a respeito do tempo, comenta esse conceito em Pedro Páramo, especialmente, quando se trata das memórias de seus personagens principais, noção aquela que se aproxima do caminho que trilhamos.

Por seu lado, Juan Pascual Buxó ${ }^{70}$, posteriormente, a trinta anos do lançamento do romance de Rulfo, define-o como um romance ausente de "centro temporal determinado"71 . Nos textos de Peralta e Buxó, a problemática do tempo se volta para o próprio texto literário, sem a busca de uma relação direta e referencial com o tempo cronológico. Sobre essa busca do tempo no próprio texto, Peralta ainda afirma que "em la novela no hay historia, sino ordenación artística de momentos, fragmentos de tiempos diversos...”. Erige, portanto, uma importante questão em relação ao que Gerard Genette ${ }^{72}$ chama de "tempo da história". Para este autor, o tempo da história é aquele ao qual se submetem os eventos no interior do romance, prescindindo de alusões ao tempo histórico, cronológico. Peralta sugere a impossibilidade de identificar o

\footnotetext{
${ }^{69}$ Peralta, Violeta. "Tiempo y eternidad" In: Peralta, Violeta. Boschi, Liliana Befumo. Rulfo, la soledad creadora. Buenos Aires: Fernango García Cambeiro, 1975.

${ }^{70}$ Buxó, Juan Pascual. "Juan Rulfo: los laberintos de la memoria”. In: CAMPBELL, Federico (sel.). La ficción de la memoria. Juan Rulfo ante la crítica. México D.F.: Ediciones Era, 2003

${ }^{71}$ Idem.

${ }^{72}$ Genette Gerard. Discurso da Narrativa. Lisboa, Vaga,1983.
} 
tempo da história em Pedro Páramo. A "ordenación artística de momentos" por Rulfo não responde em hipótese alguma à pergunta "em que tempo se passa Pedro Páramo?”.

Os diálogos do romance, fixados no passado de quem os enuncia, marcam uma temporalidade nebulosa, como é recorrente na imagem cinematográfica das lembranças de personagens. Porém, o tempo nestes fragmentos é apenas sugerido, para logo em seguida revelar-se falso. Essa problemática do tempo parece emblemática para a crítica rulfiana, ainda que abordada de diferentes perspectivas no fragmento em que Juan Preciado se depara com o casal de irmãos incestuosos ${ }^{73}$. Em meio ao seu deambular pela fantasmagórica Comala, pouco antes de ter com Dorotea e perceber-se também fatalmente acometido pela morbidez dos murmúrios que o acompanham, Juan Preciado chega à casa em ruínas em que os irmãos se abrigam. As telhas estão caídas pelo chão, abrindo brechas no telhado por onde se avista o céu que denuncia a ação do tempo. Olhando por entre as brechas do teto feitas por este tempo quase material que corrói toda a construção da casa, Preciado vislumbra o próprio tempo como um espiral imaterial, uma escada suspensa no ar. $\mathrm{O}$ tempo avança e retrocede sob seus olhos e não podemos definir ao certo em que ponto dele se encontra o personagem:

\footnotetext{
${ }^{73}$ Uma das análises mais interessantes sobre este fragmento é feita por Víctor Jiménez, a partir do antigo título da obra de Rulfo, "Una estrela junto a la luna", que confere importância especial à estrela citada no fragmento; Desta forma, Jiménez aproxima o episódio destacado à cosmovisão pré-colombiana. Jiménez, Víctor. "Una estrella para la muerte y para la vida" In: Jeppesen, Anne Marie Ejdesgaard (coord.). Tras los murmullos. Copenhague: Musuem Tusculanum Press. Universidade de Copenhague, 2010. O texto de Jiménez servirá de base para a análise desse fragmento sob a perspectiva da morte e da história nos próximos capítulos da dissertação. Conf. "Capítulo 2 - A dupla face da morte na escrita e na fotografia", p.66 "Capítulo 3 - A implicação da visão histórica de Juan Rulfo em Pedro Páramo e em suas fotografias”, p. 127.
} 
"Por el techo abierto al cielo vi pasar parvadas de tordos, esos pájaros que vuelan al atardecer antes que la oscuridad les cierre los caminos. Luego, unas cuantas nubes ya desmenuzadas por el viento que viene a llevarse el día"

E logo:

\begin{abstract}
“Como si hubiera retrocedido el tiempo. Volví a ver la estrella junto a la luna. Las nubes deshaciéndose. Las parvadas de los tordos. Y en seguida la tarde todavía llena de luz. Las paredes reflejando el sol de la tarde."
\end{abstract}

O tempo corre no alto, longe do seu alcance, longe da terra que o aprisiona no instante eterno da morte. Juan Preciado se posiciona em um lugar "privilegiado" para assistir a passagem deste tempo, assim como a posição assumida pelo fotógrafo Juan Rulfo junto à muralha em ruínas nas imagens da casa campesina. Podemos perceber a expectação do fotógrafo impregnada na imagem que nos é apresentada no caso da fotografia, segundo afirmamos, como marca da sua percepção do tempo nas imagens que apreende. Para Juan Preciado, porém, o tempo passa sem que perceba sua ação, o tempo está aparentemente alheio ao indivíduo que o observa, já que Preciado não é de fato um indivíduo, mas um cadáver enterrado numa tumba (o que demonstra que a sua posição em relação ao tempo não é tão privilegiada assim).

Os pássaros e as nuvens que observa por entre os buracos no telhado são, em relação à expressão do tempo, como a luz e a sombra que se revezam nas fotografias da casa campesina: remitem a referências ao tempo e permitem

\footnotetext{
${ }^{74}$ Pedro Páramo, pp. 58-59.
} 
sua compreensão. Os próprios buracos no telhado atuam como as depressões na muralha perpendicular à casa: demostram um outro tempo, mais lento do que aquele que a personagem observa passar sobre seus olhos. E o seu próprio tempo, despegado do continuum de uma vida, mas referente à sua própria morte, parece um referente pouco adequado para a percepção do tempo se fazer completa. Este se forma com aspectos da natureza e da sociedade, mas o indivíduo, em Pedro Páramo, vê-se incapaz de compreender sua própria locação em meio a estes dois âmbitos e, consequentemente, sua percepção em relação ao tempo é falha.

A morte de Juan Preciado, anunciada logo em seguida no romance, marca a tentativa da narrativa de se fazer em um "entretempos". Desta vez, a própria localização física deste evento no meio do romance confere à escrita enquanto matéria a divisão entre o tempo da vida e o tempo da morte. A dificuldade de percepção do tempo para o personagem é então anunciada como advinda da interferência da temporalidade dos mortos em seu discurso. Desta forma, na escrita de Rulfo se busca traduzir a problemática que envolve a conceituação do tempo fúnebre. Como alocar um discurso no tempo dos mortos?

Pouco antes daquele mesmo fragmento citado acima, Juan Preciado menciona o caráter das vozes murmuradas que ouve (ou não ouve) desde que chegara à Comala:

"Oía de vez en cuando el sonido de las palabras, y notaba la diferencia. Porque las palabras que había oído hasta entonces, hasta entonces lo supe, no tenían ningún sonido, no 
sonaban; se sentían; pero sin sonido, como las que se oyen durante los sueños." ${ }^{, 75}$

A falta de uma referência concreta no tempo e da compreensão de sua própria individualidade faz com que a narrativa que chega até Preciado se construa com palavras sem som, deficientes de seu signo linguístico. Não são vozes narrativas que se revezam no romance, mas murmúrios narrativos. Não dão vida àqueles que os usam para narrar, como no caso de Sherazade d'As Mil e uma noites, mas, ao contrário, retiram suas vidas. O leitor de Pedro Páramo, assim como o espectador das fotos de Juan Rulfo, perde-se na tentativa de fincar o discurso num tempo específico.

Gaston Bachelard, em A Dialética da Duração ${ }^{76}$, partindo de uma crítica à duração bergsoniana, define o tempo cronológico, externo ao homem, como tempo horizontal e o tempo psicológico, como tempo vertical. O tempo vertical é descontínuo e lacunar. Quanto mais distante do tempo horizontal se encontra o espírito, tanto mais livre estará. Em Pedro Páramo, o tempo horizontal está distante dos personagens, porém, a morte não dá aos espíritos, ainda que vivam no tempo vertical, a liberdade que lhes seria devida. Na verdade, este tempo vertical os aprisiona. Seus pensamentos ricocheteiam nas paredes da tumba sob o solo de Comala e desconcertam seus interlocutores - e leitores. Não estamos diante de um fluxo de consciência desapegado do tempo cronológico, estamos diante do cruzamento que marca a mescla destes tempos e que gera os murmúrios dos personagens.

\footnotetext{
${ }^{75}$ Ibidem, p.52

${ }^{76}$ Bachelard, Gaston. A Dialética da Duração. São Paulo: Ática, 1988.
} 
O tempo da fotografia também ricocheteia na moldura da foto. Passado e presente se atualizam e não convergem para o futuro. $\mathrm{O}$ futuro, na fotografia, está morto pelo instante criado pelo clique do fotógrafo. Em Pedro Páramo, a construção de um tempo semelhante se dá justamente com a morte de todos os personagens, anunciada desde suas primeiras páginas, e é medido com a morte de Juan Preciado. O instante da confissão da morte de Preciado é fundamental no romance, não enquanto temática (a morte mais importante do romance seria a de Pedro Páramo), mas por sua disposição no centro da narrativa, reforçando a ideia de um alvo, de uma mirada da escrita que busca o ponto de toque de algo inapreensível, de um tempo solúvel em presente e passado, marcando, justamente, a impossibilidade da apreensão. A perda de referência é tão profunda, desnorteia de tal maneira o discurso, que até mesmo a feminilidade da voz de Dorotea, que marcaria seu gênero, se perde. Juan Preciado se refere à Dorotea, antes de confessar-lhe sua própria morte, por Doroteo $^{77}$ :

\author{
“- ¿Quieres hacerme creer que te mató el ahogo, Juan \\ Preciado? Yo te encontré en la plaza, muy lejos de la casa de \\ Donis, y junto a mí también estaba él, diciendo que te estabas \\ haciendo el muerto. Entre los dos te arrastramos a la sombra \\ del portal, ya bien tirante, acalambrado como mueren los que
}

\footnotetext{
${ }^{77} \mathrm{O}$ problema linguístico referido chama atenção para uma característica da língua náhuatl. Os substantivos, em náhuatl clássico, não distinguem o gênero gramatical. Apenas os nomes quando usados no vocativo possuem desinência capaz de diferenciar o gênero. A morte de Juan Preciado faz com que a realidade criolla seja atravessada pela mitologia pré-hispânica, como apontou Marin Lienhard. A ida de Preciado a Comala, para o antropólogo, se assemelha a ida de Quetzalcoatl ao Mictlán. Lienhard, Martin. La voz y su huella: escritura y conflicto étnico-social en América Latina (1492-1988). Casa de las Américas: Havana, 1990. Uma vez que Preciado atravessa a fronteira entre o mundo dos vivos e o mundo dos mortos, portanto, as culturas se misturam. $\mathrm{O}$ equívoco na desinência de gênero no nome de Dorotea poderia aludir ao contato entre a estrutura do castelhano com a estrutura do náhuatl que em nenhum outro momento da narrativa pode ser aludido.
} 
mueren muertos de miedo. De no haber habido aire para respirar esa noche de que hablas, nos hubieran faltado las fuerzas para llevarte y contimás para enterrarte. Y ya ves, te enterramos.

- Tienes razón, Doroteo. ¿Dices que te llamas

Doroteo?

- Da lo mismo. Aunque mi nombre sea Dorotea. Pero da lo mismo.

- Es cierto, Dorotea. Me mataron los murmullos" ${ }^{\text {78. }}$.

$\mathrm{O}$ discurso atrelado aos personagens encara uma recorrente dificuldade para se firmar ao longo do romance quando aqueles buscam pronomes, verbos ou mesmo seus interlocutores. Há, representada pelos murmúrios destes personagens, uma grande dificuldade para nomear.

No momento em que Pedro Páramo relembra o dia da morte de seu pai anunciada pela mãe, a mulher aparece no batente da porta de seu quarto, cobrindo parcialmente a luz que entra pelas suas costas, impedindo que amanhecesse no quarto onde ele dormia. O jogo de luz e sombra (outra vez) e o posicionamento da mulher diante de uma porta nos faz lembrar o par de fotos do homem no templo de Sanctorum ${ }^{79}$. O jogo do tempo é marcado literariamente com as mesmas peças, a luz e a sombra, jogo entre presente e passado que se confundem na memória narrativa. $\mathrm{O}$ fragmento, em terceira pessoa, apresenta uma pergunta de Pedro, em discurso indireto, dirigida à mãe. O personagem pergunta quem a havia matado. Esta pergunta somente pode ter

\footnotetext{
${ }^{78}$ Ibidem, pp. 62-63.

${ }^{79}$ Beatrice Tatard em Juan Rulfo Photographe; Esthétique Du Royaume Des Âmes dá enfoque à presença simultânea das sombras na narrativa e na fotografia rulfianas, assim como ao vento (fotografado e narrado como uma presença constante em Pedro Páramo) e à utilização da metonímia. Tatard, Beatrice. Juan Rulfo Photographe; Esthétique Du Royaume Des Âmes. Paris: L' Harmattan, 1994.
} 
sido feita a partir do presente de Pedro, que se diferencia do tempo da terceira pessoa que predomina no fragmento e do tempo da própria ação narrada. A pergunta denuncia a variação de tempos neste fragmento. A imagem da mãe parada ao batente da porta, que para a luz do dia impedindo a sua entrada no quarto em que se encontra Pedro menino, também apreende o tempo atrás de si e o suspende para a representação da morte que dará lugar a sequência de mortes anunciadas ao longo do romance. O tempo narrativo da terceira pessoa, neste fragmento, é suspenso com a irrupção desses tempos divergentes, o presente de Pedro e o presente da mãe, que destoam do tempo da memória ${ }^{80}$ :

\footnotetext{
"Se levantó despacio y viola cara de una mujer recostada contra el marco de la puerta, oscurecida todavía por la noche, sollozando.

-¿Por qué lloras, mamá? -preguntó; pues en cuanto puso los pies en el suelo reconoció el rostro de su madre.

-Tu padre ha muerto -le dijo.

Y luego, como si se le hubieran soltado los resortes de su pena, se dio vuelta sobre sí misma una y otra vez, una y otra vez, hasta que unas manos llegaron hasta sus hombros y lograron detener el rebullir de su cuerpo. Por la puerta se veía el amanecer en el cielo. No había estrellas. Sólo un cielo plomizo, gris, aún no aclarado por la luminosidad el sol (...). Y aquí, aquella mujer, de pie en el umbral; su cuerpo impidiendo la llegada del día; dejando asomar, a través de sus brazos, retazos de cielo, y debajo de sus pies regueros de luz; una luz
}

\footnotetext{
${ }^{80}$ Em Los cuadernos de Juan Rulfo (1995), o texto "Mi padre" refere-se a uma situação muito semelhante a narrada neste trecho da narrativa de Pedro Páramo. Nota-se um forte teor autobiográfico na descrição do anúncio da morte de Pedro Páramo. A própria mãe de Rulfo também o teria acordado no meio da noite para informar-lhe sobre o assassinato de seu pai, Juan Nepomuceno Pérez Rulfo em 1924, quando o escritor tinha apenas sete anos.
} 
asperjada como si el suelo debajo de ella estuviera anegado en

lágrimas. Y después el sollozo. Otra vez el llanto suave pero

agudo, y la pena haciendo retorcer su cuerpo.

-Han matado a tu padre.

- YY a ti quién te mató, madre?"

Com suas bases nesse tempo problemático, que oscila entre o tempo da memória dos personagens, o tempo da emissão dos murmúrios e o tempo do narrador, Juan Preciado não consegue ter sucesso na busca de seu pai e, portanto, de sua própria história, pois não há um tempo fixo e linear em que sua história possa se cravar. A base para a própria aparição da mãe se dá sob um solo "anegado en lágrimas", um terreno desfeito no líquido que permite as contradições do tempo no romance. Os "ruídos callados" emitidos do lado de fora do quarto em que se passa a cena dão coro à sequência de paradoxos que se repetirão por toda a narrativa.

Outro momento-chave para a percepção da confusão do tempo da narrativa se refere à amada de Pedro Páramo, Susana San Juan. Em meio a seus delírios pouco antes de morrer, recebe o padre Rentería, quem lhe leva a extrema-unção. Após saber o propósito da visita, Susana pede que o padre saia e, ouvindo os seus passos longínquos "que siempre le dejaban una sensación de frío, temblor y miedo”, pergunta: “¿[p]ara qué vienes a verme, si estás muerto?" ${ }^{82}$. Nesse fragmento, ecoa para o leitor a pergunta que Dorotea faz a Preciado quando este tenta ouvir os murmúrios: ¿[p]ero de qué tiempos hablará?",8384

\footnotetext{
${ }^{81}$ Pedro Páramo, pp. 28-29.

${ }^{82}$ Ibidem, p. 149.

${ }^{83}$ Ibidem, p. 84.
} 
Essa dificuldade que têm os personagens de Pedro Páramo em lidar com suas referências atua em favor da série de fracassos e mortes por que passam. O fracasso na busca do pai por Juan Preciado, e sua morte, é o maior exemplo.

No início de sua viagem, Preciado carrega consigo um retrato da mãe, deteriorado pelo tempo, para ajudá-lo na busca de sua história e como indício de comprovação de sua ascendência. Surge na narrativa rulfiana a noção da fotografia como um elemento da trama que permite pensar sua concepção como um objeto portador da verdade e reconstrutor da história. Porém, como já mencionado, a foto por si só não é a história. Munido com a fotografia, Preciado parte para a reconstrução da história perdida, como se o retrato pudesse servir como um potencializador de lembranças passadas. Para retomar o romance de Saer, Glosa, o seu narrador afirma que "el recuerdo es una fotografía o una imagen sombría estampada en el interior de su cabeza" ${ }^{\natural 5}$.Essa imagem sombria requer um grande esforço para ser acessada e pode se tratar, na verdade, de uma imagem-lembrança perdida para sempre. Em nosso romance, Pedro Páramo, a tentativa de mostrar o retrato da mãe para fazer Pedro Páramo lembrar-se dela revela a problemática presente posteriormente no romance de Saer. Uma vez já apagados da memória de Pedro Páramo, como a mãe adverte logo antes de morrer ("el olvido en que nos tuvo, mi hijo,

\footnotetext{
${ }^{84}$ A confusão em relação ao tempo revelada pelos fragmentos em que os personagens se perguntam sobre a morte, e devida à morte, se contrapõe ao que ocorre, por exemplo, no conto "El perseguidor" de Julio Cortázar. No relato, o músico Johnny, em um ataque de histeria, deixa de tocar seu instrumento e diz: "[e]sto lo estoy tocando mañana" e, depois, "[e]sto ya lo toqué mañana...". A consciência do futuro traz a morbidez que carregam os personagens de Pedro Páramo presos ao passado para o conto de Cortázar. Essa consciência, contudo, revela um futuro falso, já que Johnny se deixa abater e acaba tornando-se um moribundo. A epígrafe do conto que contém uma citação do apocalipse bíblico, "Sé fiera hasta la muerte", é a referência explícita à morte, que aqui emana do futuro, deixada pelo autor. Cortázar. Julio. "El perseguidor”. In: Cuentos completos 1. Madri: Punto de Lectura, 2007.

${ }^{85}$ Saer, Juan José. Glosa. Buenos Aires: Seix Barral, 1985, p.36.
} 
cóbraselo caro" [grifo nosso]), o retrato trabalha ainda mais contra as intenções do filho de reviver uma imagem-lembrança já perdida.

Ainda em Glosa, completando a comparação de uma recordação a uma fotografia, o narrador completa que "las emociones y los sentimientos de humillación o de cólera forman unos agujeros de bordes negros y requebrajados como si la imagen estuviese siendo atravesada en muchos puntos de su superfície por la brasa de un cigarrillo" ${ }^{„ 86}$. Em Pedro Páramo, A fala da mãe de Preciado desde seu leito de morte anuncia que as emoções hão de invadir suas lembranças de "buracos". Pedro Páramo é um "rencor vivo", como afirma Abundio durante a viagem de Preciado à Comala, portanto, suas lembranças estão repletas de "sentimientos de cólera o de humillación" que, para retomar as palavras do narrador de Saer, são os responsáveis pelos buracos causados nas imagens-lembranças. O retrato da mãe carregado por Preciado está carcomido nas beiradas e, no centro da imagem, há justamente um buraco do tamanho de um dedo, aberto onde estaria o coração da mulher fotografada - uma lembrança vinda da memória que compõe a história de Pedro Páramo não poderia estar livre dessas avarias.

O buraco no retrato levado à Comala também atua como um vodu que trabalha para tirar algo da humanidade da mãe, trabalho este já temido pela própria mulher retratada, como mencionado por Preciado ("Mi madre siempre fue enemiga de retratarse. Decía que los retratos eran cosa de brujería”). Desta forma, vê-se presentificar nestas duas passagens, em Pedro Páramo e em Glosa, a ação física do tempo que age sobre a matéria, provocando os buracos e os defeitos na moldura, além de depararmo-nos com uma característica

\footnotetext{
${ }^{86}$ Ibidem. P.?
} 
irracional do tempo, aquela que o liga à bruxaria, no caso do romance mexicano, e o que o liga aos sentimentos que revolvem a lembrança, em Glosa.

Além de o retrato compor o conjunto das imagens fotográficas que em sua própria composição atiça a discussão sobre o aprisionamento do tempo e a simultaneidade entre passado e presente, ou seja, a ação mais inapreensível do tempo, suas marcas de deterioração enfatizadas pelo narrador de Pedro Páramo entram em contato com as características apontadas no fragmento dos irmãos incestuosos e no par de fotografias da casa campesina. Essas marcas de deteriorações físicas, no retrato e na casa da trama narrativa e no par de fotografias da casa campesina, atuam em conjunto para remitir à expressão do tempo, de forma fotografada e narrada, indicando a ação do tempo agindo sobre o mundo material.

A morte do próprio Pedro Páramo, no encerramento do romance, sinaliza de forma emblemática os pontos levantados acima a respeito da ação do tempo. O homem cujo poder subjugou toda uma cidade e seus habitantes, agora caminha com grande dificuldade. $\mathrm{O}$ cacique tenta falar, mas as palavras não lhe saem, e acaba desmoronando como um monte de pedras. A fala que se encerra dentro de si marca a dificuldade da construção do discurso em um romance que esboça uma narrativa fora do tempo convencional, em que a linearidade é substituída por um vai e vem de passado e presente e pela mescla desses dois tempos em diversos fragmentos, como apontado. $\mathrm{O}$ andar dificultoso e a fala encerrada ainda evidenciam a angústia que acomete o homem em seus últimos instantes de vida, após perder suas terras, assistir o povo de Comala debandar para outras cidades e, principalmente, após a morte de seu amor romântico representado por Susana San Juan. O desmoronamento 
em pedras nos traz de volta a sucessão de ruínas presentes nas obras de Rulfo, remetidas tanto pelas fotos da arquitetura do interior do país com suas pedras carcomidas pelo tempo, quanto pelas remissões das ruínas em que se encontra Juan Preciado ao chegar em Comala. Pedro Páramo é um rancor vivo e, portanto, sobreviverá naquelas pedras expostas à ação do tempo, perdidas para sempre no deserto de Comala.

\footnotetext{
"Se apoyó en los brazos de Damiana Cisneros e hizo intento de caminar. Después de unos cuantos pasos cayó, suplicando por dentro; pero sin decir una sola palabra. Dio un golpe seco contra la tierra y se fue desmoronando como si fuera un montón de piedras, 87
}

Com a morte do cacique ao final do livro, evidencia-se que o futuro, o desenvolvimento do romance em uma estrutura tradicional, é problematizado, fato já anunciado com a sequência de mortes que rodeiam Juan Preciado até a sua própria morte na metade do romance. O "para sempre" que encerra o romance identificado na imagem literária das pedras, ironicamente, quase nos aproxima dos finais dos contos de fadas. Porém, o que nos distancia grosseiramente daqueles, além do fato de não termos chegado até este ponto da narrativa embebidos de uma história contada aos moldes tradicionais, é o fato de que a eternidade aqui remetida não é a da vida, mas a da morte. Uma morte que não alivia, de forma alguma, os sortilégios sofridos em vida, apenas os condensa e os petrifica.

\footnotetext{
${ }^{87}$ Pedro Páramo, p. 131.
} 
A impossibilidade de distinguir um marco temporal claro nas fotografias e na narrativa de Pedro Páramo nos apresenta discursos problemáticos, que dificultam com que estruturemos uma história para a imagem que observamos e para a narrativa que lemos. Sobre o que conta Pedro Páramo e o que vemos na fotografia? Juan Rulfo afirmou, sobre seu romance, que conta a história de um povo e não a história de um ou outro personagem ou de uma cidade específica do interior mexicano. Como um povo conta a sua história? Como delimitar o espaço temporal de atuação de um povo? Substituindo-se povo por imagem fotográfica, essas perguntas podem ser feitas também em relação às fotografias rulfianas. Enquanto se tenta fotografar um povo harmônico e homogêneo no pós-revolução mexicana, Rulfo apresenta fotografias que destoam completamente desta harmonia. Revela que apenas com as contradições que lhe são inerentes é possível retratar o povo mexicano. Em sua narrativa, em oposição aos romances da revolução que o antecedem, demonstra que apenas dando voz a mortos é possível falar sobre um povo. E dar voz aos mortos é situá-los em uma atitude que lhes é extremamente dificultosa. O que se espera dos mortos é o silêncio e a tranquilidade, e não o impulso angustiante do narrar desde a tumba. Da mesma forma, o que se sabe do tempo é o seu próprio silêncio e não como se pode narrá-lo. O que cabe ao povo morto de Comala é forjar-se no relato cuja base temporal é movediça, e no relato se forja também o próprio tempo, fazendo com que as memórias rodopiem sobre os próprios pés, como na imagem da mãe de Pedro Páramo no batente da porta quando da notícia da morte de seu pai que tenta se erguer sob um solo líquido. De tal modo, Rulfo envolve o leitor nessa complexa busca de uma história. 
Percebemos, com isso, a presença de um "tempo dos mortos", um instante eternizado no momento em que a morte toca o corpo vivo, em que se mesclam presente e passado e se esvanece o futuro. O tempo dos mortos é o tempo da narrativa e das imagens fotografadas de Juan Rulfo.

\section{Capítulo 2 - A dupla face da morte na escrita e na fotografia rulfianas}

\section{A morte no México}

Grande protagonista da maior festa do país, a morte é tida como uma das representantes da identidade nacional mexicana. Não é apenas um símbolo da cultura popular, mas é também preservada pelo Estado como parte daquela identidade. Os crâneos pintados com cores alegres, as caveiras anônimas tocando violão e usando chapéus de abas largas, que enfeitam as cidades mexicanas nos dias 31 de outubro, 1 e 2 de novembro, são os símbolos do suposto exotismo que se expressa na representação mexicana da morte diante das demais culturas ocidentais. Enquanto, à primeira vista, grande parte dessas culturas vê a morte com cautela, muitas vezes com um pesado silêncio, e lhe atribui cores escuras, no México, a celebração do Día de los muertos é realizada em meio a uma festa ruidosa e colorida.

Em El laberinto de la soledad, Octavio Paz (2008) ressalta o fato de o mexicano burlar-se da morte, rebaixando-a de uma figura sentenciadora, a uma figura irrisória. Esse rebaixamento pode ser notado, por exemplo, nos poemas cômico-populares publicados nos jornais mexicanos no Día de los muertos, as 
rimas de calaveras $^{88}$, e nas ilustrações de José Guadalupe Posada (1852-1913), criador da Catrina ${ }^{89}$. O movimento apontado por Paz se assemelha à carnavalização referida por Mikhail Bakhtin ao comentar a obra de Rabelais. Segundo Bakhtin, a cultura popular é a grande propulsora do realismo grotesco presente na literatura, desde a Idade Média até o início do século XX, e compõe a estética do carnaval popular daquele primeiro período. Desvencilhando-se dos clássicos, os autores da literatura realista grotesca criam a imagem de um corpo aberto, incompleto, referido por suas perfurações, secreções e parte inferior; é um "corpo simultaneamente no umbral do sepulcro e no berço" 90 .

Assim como o nascimento, a morte é um elemento importante para a composição da figura grotesca exposta por Bakhtin que, em um mesmo corpo, possui um caráter embrionário e o de uma morte eminente, dois elos observados no ponto onde se unem, onde entram um no outro ${ }^{91}$. Verifica-se essa característica apontada pelo russo no romance rulfiano Pedro Páramo. Assim se compõe a figura da personagem Dolores Preciado no romance do mexicano, que faz com que seu filho, Juan Preciado, prometa-lhe uma viagem à Comala para cobrar o esquecimento da mãe e do filho pelo pai Pedro

${ }^{88}$ Sobre as rimas de calaveras, recomenda-se a leitura da tese de dissertação defendida na Univesidad de Nuevo León: García, Rodolfo Gutiérrez, Las calaveras: función social. Investigación hemerográfica. Monterrey: Universidad de Nuevo León, 2000. [on-line] 22/05/2014. Disponível em<http://eprints.uanl.mx/2669/1/1020145387.PDF>.

${ }^{89}$ Esqueleto feminino vestido com trajes criollos que ilustrou inúmeras revistas políticas de posições opostas, anteriores à Revolução Mexicana, e que foi adotado posteriormente por Diego Rivera em seus murais.

${ }^{90}$ Bakhtin, Mikhail. Op. Cit., p. 23. A relação entre berço e tumba apontada por Bakhtin é aludida, também, em uma das várias cidades que cria Ítalo Calvino em suas Cidades invisíveis. No romance de Calvino, o personagem Marco Polo descreve ao imperador mongol Kublai Khan as cidades por que passou. Marco Polo descreve Laudômia como uma cidade que vive uma realidade tríplice. Está dividida entre a cidade dos vivos, a cidade dos mortos no cemitério que reflete a cidade dos vivos (todos os que vivem na primeira cidade tem seu equivalente debaixo da terra) e a cidade dos não-nascidos. Em Laudômia, a morte se relaciona diretamente com a gestação da vida, como apontado por Bakhtin, marcando um ciclo mítico que ultrapassa os limites da Idade Antiga. Calvino, Ítalo. As cidades invisíveis. São Paulo: Companhia das Letras, 1990.

${ }^{91}$ Bakhtin, Mikhail. Op. Cit., p. 22 
Páramo $^{92}$. Porém, na cidade fantasmagórica, o que Preciado encontra é apenas silêncio, mortos e desolação, e nessa cidade também acaba morrendo. A vida e a morte estão presentes na figura dessa mãe que conduz o próprio filho ao seu fim. ${ }^{93}$

A morte se apresenta em Bakhtin como elemento advindo da cultura popular, e a escolha desse símbolo como um dos estandartes da cultura e da identidade nacional no México ressalta também essa mesma origem. Não é à toa que muitos destes símbolos nacionais que resistem nos dias atuais surgiram a partir da Revolução Mexicana, ainda que a morte apresente uma representação peculiar que remonta desde os tempos do México colônia até a América pré-hispânica ${ }^{94}$.

Neste sentido, é interessante notar que Benedict Anderson, em Comunidades Imaginadas $^{95}$, marca o nascimento do nacionalismo nas sociedades europeias e estadunidense com o erguimento de sepulturas de caixões vazios dos soldados mortos em batalha. É ao redor dessas mortes invisíveis, desses mortos idealizados, que se começa a desenhar a comunidadenação imaginada. Anderson também contrapõe as sociedades religiosas às nações que, com seus sistemas culturais, passam a ocupar o lugar daquelas primeiras. Ainda que autoexcludentes, na sua concepção, a religião e o nacionalismo têm a mesma base: são incontestáveis. No México, o nacionalismo e a morte estão intimamente interligados. O nacionalismo

\footnotetext{
${ }^{92}$ GARCÍA, David. Morir en Comala: mitocrítica de la muerte en la narrativa de Juan Rulfo. México D.F: Ediciones Coyoacán, 2005.

${ }^{93}$ Percebe-se uma semelhança do enredo destacado em Pedro Páramo com a história medieval da rainha dos francos, Clotilde, narrada pelo historiador medieval Gregório de Tours. Na narrativa, Gregório de Tours conta que Clotilde pede que seus filhos vinguem a morte de seus avós, o que acaba levando-osà morte, assim como, posteriormente, os seus próprios netos. In: Grégoire de Tours, "Livre VII" e "Livre IX”, Histoire des Francs. Paris: Les Belle Lettres, 1999.

${ }^{94}$ Ainda que os efeitos da Revolução Mexicana, que afetam sua interpretação a partir do presente, principalmente após sua institucionalização, tenham se afastado de suas causas populares.

${ }_{95}$ Anderson, Benedict. Comunidades imaginadas. São Paulo: Companhia das Letras, 1999.
} 
mexicano, atrelado à figura da morte que, por sua vez, faz presente a religião, cria, portanto, um registro nacional híbrido.

A presença de diversas culturas sobrepostas na figura da morte enfatiza o seu "dinamismo cultural" ". Muitas das características apontadas por Paz sobre a relação do mexicano com a morte parecem estar em acordo com o popular europeu exposto por Bakhtin quando reflete sobre a Idade Média.

Voltando às postulações de Paz, para completar o quadro que erige, o poeta faz referência à busca da catarse pelo mexicano macho, que é o homem nascido naquele país, geralmente calado e vítima da opressão dos poderes que se impõem sobre ele, desde o Estado até o caciquismo. O macho, através das várias festas tradicionais, das irrefreáveis borracheiras (“bebedeiras”) e da carnavalização da figura mais temida pela humanidade, a morte, demonstra sua solidão, sua resignação e sua esquiva de si. O quadro que esboça Paz traz as cores de uma modernidade que complexifica a atitude do indivíduo frente ao todo que compõe a festa popular e do qual deve tornar-se parte. No caso do macho mexicano, é justamente a atitude moderna de cindir-se em sujeito social e indivíduo solitário que exemplifica essa complexidade. Ao integrar-se à festa corporalmente, a individualidade e, portanto, a solidão do mexicano, é apartada; porém, com esse mesmo movimento, reafirma-se sua individualidade que ressurgirá findas as celebrações. Aparentemente, portanto, a morte é vivida em dois âmbitos na vida do mexicano: o primeiro, coletivo, momento da festa, e o segundo, individual, momento da dor do luto e do sentimento de solidão ${ }^{97}$.

\footnotetext{
${ }^{96}$ Bourdieu, Pierre. As regras da arte. Gênese e estrutura do campo literário. Queluz de Baixo: Editorial Presença, 1996.

${ }^{97} \mathrm{Paz}$ faz notar, também, que essa caracterização recai exclusivamente sobre o mexicano de sexo masculino, dado o exacerbado machismo que predomina no país, assim como nos demais países latino-americanos. É interessante notar que os personagens de Juan Rulfo são em sua maioria masculinos. As mulheres, quando presentes, são débeis e sofredoras, como Dolores Preciado, ou
} 
O antropólogo Stanley Brandes, por sua vez, trata a morte no México a partir de estudos realizados em diferentes tribos indígenas. ${ }^{98}$ Conclui que a relação do mexicano varia de acordo com o grupo social referido dentro do país. Observando alguns funerais, percebe que, enquanto a morte é vista por algumas tribos com precaução e temor, por outras, é vista com maior resignação. Porém, o sofrimento nos funerais está sempre presente: diante da morte de seus entes queridos, os mexicanos atuariam como grande parte dos enlutados ao redor do mundo ${ }^{99}$. Propõe, portanto, que a figura da morte levada pelo turista como souvenir após uma viagem ao México se refere, antes de tudo, a um símbolo imaginativo construído como mediador de uma relação que não seria mais afável neste país do que nos demais países que o cercam.

A herança cultural pré-colombiana é outro elemento essencial para se compreender a atitude dos povoados do interior do país diante da morte, pois muitos de seus símbolos permanecem nessas zonas, ainda que já mesclados em grande parte com a cultura cristã. A visão indígena em relação à morte é muito diferente daquela levada ao continente americano pelos espanhóis quando da Conquista e que se vê esboçada nas postulações de Bakhtin quanto às festas populares expostas acima. Os inúmeros estudos funerários das populações astecas e maias são os grandes responsáveis pelo que se sabe hoje daquelas sociedades antigas. Uma das grandes descobertas dos muitos arqueólogos que

padecem de problemas psicológicos, como Susana San Juan, ou servem como guia do inframundo, como no caso de Dorotea, todas estas personagens presentes no romance Pedro Páramo, ou, ainda, servem para a perdição do homem, como no caso de Bernarda Cutiño, personagem da pequena novela El Gallo de Oro.

98 Brandes, Stanley. "Visiones mexicanas de la muerte". In: Martos, Juan Antonio Flores. González, Luisa Abad. Etnografias de la muerte y las culturas en América Latina. Cuenca: Ediciones de la Universidad de Castilla - La Mancha: AECI, 2007.

99 A morte de Gabriel García Márquez, que residiu no país desde 1975, em 2014, é um grande exemplo da comoção que toma o mexicano diante da morte de seus queridos. Ainda que se tratasse de uma figura pública e de um estrangeiro, não foram poucos os que se emocionaram, quando da homenagem fúnebre realizada no Palacio de Bellas Artes da Cidade do México, diante dos restos mortais do célebre escritor colombiano e Nobel de literatura. 
vêm se debruçando sobre essas culturas é o sentido de continuidade entre a vida terrena e a vida no mais além, proporcionado pela morte, para aquelas sociedades $^{100}$. Os objetos enterrados junto aos corpos mumificados, o tratamento dado aos cadáveres, os animais e os demais serviçais dos grandes governadores enterrados junto aos seus corpos demonstram que aqueles indígenas acreditavam que a morte era apenas a travessia deste para outro mundo, onde todas as regalias acumuladas na primeira vida seriam mantidas. $\mathrm{O}$ cão enterrado com a maioria dos cadáveres é o símbolo dessa travessia, pois seria quem conduziria os mortos ao inframundo. A morte, portanto, era cultuada como a grande mediadora entre os dois mundos. $\mathrm{O}$ tipo de morte que acometia aqueles indígenas também influía em seu destino no mundo extraterreno. Os sacrifícios humanos realizados nas sociedades astecas, por exemplo, não eram apenas uma homenagem ao deus em questão, mas também uma oportunidade para aquele que seria sacrificado de alcançar a vida sobrenatural com grande dignidade e ocupar um lugar de destaque na sociedade do mais além. "Dime como mueres y te diré quién eres", escreveu Octavio Paz, seguramente inspirado pela lógica pré-hispânica ${ }^{101}$. Sacrificar-se significava, também, alimentar o ciclo mítico, pois segundo La leyenda de los soles, lenda asteca, os deuses teriam se sacrificado para dar vida ao homem ${ }^{102}$.

A relação dos indígenas com a morte demonstrava a sua visão de mundo, sua religião e sua política. ${ }^{103} \mathrm{O}$ culto ao deus Huitzilopochtli em

\footnotetext{
${ }^{100}$ Moctezuma, Eduardo Matos. Muerte a filo de obsidiana: los nahuas frente a la muerte. México D.F: FCE, 2013.

${ }^{101}$ Citado por Eduardo Matos Moctezuma, em Moctezuma, Eduardo Matos. Muerte a filo de obsidiana. Los nahuas frente a la muerte. México: FCE, 2013.

${ }^{102}$ Moctezuma, Eduardo Matos. Op. Cit.

${ }^{103}$ Benedict Anderson afirma que o grande mérito das religiões, além do seu papel na legitimação do sistema de dominação e exploração, é a sua preocupação com o homem no universo e com o sentido da vida. A religião se interessa pelos vínculos entre os mortos e os ainda não nascidos. In:
} 
Tenochtitlán (atual Cidade do México), representado por uma caveira imponente vestida em penas de beija-flor, evidencia o enaltecimento dos mortos. A provável divinização de um herói que deu origem àquele deus acentua ainda mais essa realidade. A morte era o caminho para a divindade e para a glória eternas. Muitos poemas nahuatls louvam a morte e sublimam a passagem para aquela outra vida. A recorrência das caveiras como ornamentos em utensílios domésticos daqueles que ocupavam os patamares sociais mais elevados das sociedades pré-hispânicas também é notável ${ }^{104}$. Em Teotihuacán, antiga cidade majestosa e hoje um dos principais sítios arqueológicos do país, onde se localizam as pirâmides do deus do Sol (Quetzalcóatl), ou Serpente Emplumada, e da Lua (Coyolxauhqui), encontrou-se uma escultura representando a morte com a parte frontal de um crâneo pintado de vermelho e envolto em uma espécie de corola, representação que reforça a ideia do incessante ciclo travado entre vida e morte ${ }^{105}$. A cidade é divisada pela Calzada de los Muertos, de que pouco se sabe; os próprios astecas, que encontraram Teotihuacán abandonada e suas pirâmides semiconstruídas, nomearam-na Calzada de los Muertos por crerem que a antiga população nahua que habitara a cidade enterrava seus mortos nas pirâmides que a rodeavam. A relação dessa sociedade antiga e desconhecida aos astecas com a morte foi reinterpretada e contribuiu para o término da construção da pirâmide

Anderson, Benedict. Op. Cit. Seguindo as postulações de Anderson, percebemos que a religião cuida de tais problemas desde a história pré-hispânica até a idade moderna.

${ }^{104}$ Garcia, David. Op. Cit.

${ }^{105}$ Moctezuma, Eduardo Matos. Op. Cit., p. 23. 
do Sol pela civilização que a sucedeu, e para o enriquecimento da cosmovisão dessa última comunidade ${ }^{106}$.

Em diálogo com a cosmogonia pré-hispânica, uma das fotografias de Rulfo focaliza um chacmool, escultura de pedra que representa uma figura antropomorfa, deitada de barriga para cima, rosto voltado para a esquerda, busto erguido e pernas recolhidas e dobradas em 90 graus. Vários chacmooles foram encontrados na região da antiga Tenochtitlán, atual Cidade do México, em Chichén-Itzá, estado de Yucatán, e em Tula, estado de Hidalgo. Rulfo fora até Tula para fotografar o chacmool em questão. Pouco se conhece sobre a utilidade dessa figura recorrente na Mesoamérica, porém se sabe que era um dos elementos presentes em rituais religiosos que se relacionavam com os sacrifícios humanos. Os chacmooles encontrados na região da antiga Tenochtitlán possuem várias características físicas próprias do deus Tláloc, relacionado às chuvas e fertilidade. No dorso dos chacmooles, se depositavam oferendas como tamales, pulque, tortillas ou o coração de sacrificados. A figura, portanto, tem uma relação estreita com o lugar que ocupava a morte nas comunidades pré-hispânicas.

106 Tal ato é recorrente na história da dominação de povos indígenas por outros indígenas, o que permite a convivência de distintas culturas pela sociedade dominante. As culturas indígenas se alimentavam reciprocamente. 


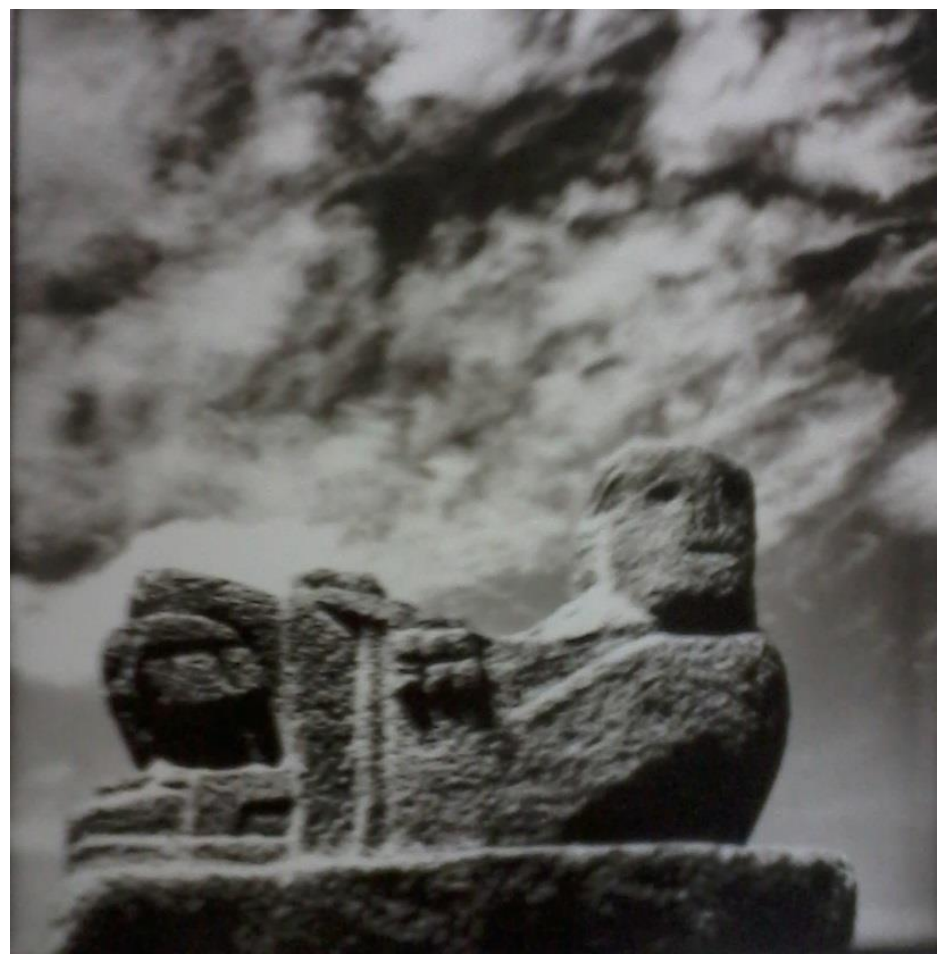

Figura 6 -Juan Rulfo, Chacmool em Tula, s/d.

A fotografia do chacmool de Tula feita por Rulfo dialoga com o mistério que ronda as tentativas ${ }^{107}$ de definir a função dessa figura na cosmogonia indígena. Rulfo, com o ângulo escolhido para enquadrar a figura, confere dignidade $^{108}$ ao chacmool. Fotografada de baixo para cima, se prolongando para o céu, mesmo que com a postura deitada, a escultura de pedra é contraposta às nuvens que desenham linhas retas, como se esboçassem um movimento suave sobre a pedra que perdura imóvel e calada. O fotógrafo,

${ }^{107}$ Sobre essas tentativas, ler Austín, Alfredo López e Luján, Leonardo López. "Los mexicas y el chacmool". Arqueología Mexicana. [on-line] N. 49. Cidade do México, Instituto de Nacional de Antropología e Historia da Universidad Nacional Autónoma de México, 2001. Disponível em <http://www.mesoweb.com/about/articles/AM049.pdf>. ISSN 0188-8218.

${ }^{108}$ Faço eco, aqui, de uma característica empregada por Sebastião Salgado ao se referir à fotografia de uma tartaruga gigante de Galápagos, presente em sua exposição "Gêneses". O fotógrafo brasileiro diz que ficou muito tempo observando a tartaruga, buscando um ângulo que lhe desse dignidade. Como mencionado no capítulo anterior, Juan Rulfo também despendia várias horas em frente aos objetos que fotografava, talvez buscando a mesma dignidade citada por Salgado. Pelo menos é dignidade o que podemos perceber nos objetos e pessoas a que as lentes do mexicano se voltaram, o que se difere sobremaneira da decadência que sua escrita imprime ao mundo narrado. A fala de Sebastião Salgado se deu em ocasião da entrevista ao programa televisivo Roda Viva, da TV Cultura, de 16/09/2013. 
aqui, posiciona a figura em seu ambiente ideal, tal como é definido pelo personagem Filiberto no conto de Carlos Fuentes, "ChacMool": "[e]stas figuras necesitan sol, vertical y fogoso: esse fue su elemento y condición"109.

No conto de Fuentes, o narrador tem contato com o diário de Filiberto, seu amigo recentemente falecido. No diário, este personagem conta sobre sua admiração por peças pré-hispânicas e sobre a aquisição de um chacmool. Conta ainda sobre a grande surpresa com que se depara após a aquisição: o chacmool que tem em seu sótão se humaniza e passa a controlá-lo. Diferente do que pensava em relação à necessidade do sol, é da chuva que parece sobreviver a figura, comparada por Filiberto ao deus Tláloc, assim como fizeram os arqueólogos em seus estudos ${ }^{110}$. A figura pré-hispânica não deixa com que Filiberto saia sem seu consentimento e acaba forçando a fuga do homem. O personagem foge para uma pousada em Acapulco e acaba morrendo no mar, supostamente ao tentar nadar.

Tanto Rulfo como Fuentes resgatam a figura do chacmool das entranhas da tradição pré-hispânica e criam, através da fotografia e da narrativa um cenário completamente outro, em que dialogam a visão da morte contemporânea e o resquício do que nos chega da visão da morte pré-hispânica. O personagem aficionado pela história pré-colombiana no conto de Fuentes menciona que o vendedor que lhe repassou o chacmool pintava a barriga das esculturas com tinta vermelha para conferir a elas maior autenticidade. Já se chegou a afirmar que sacrifícios humanos eram feitos justamente no dorso dessa figura ${ }^{111}$. O conto, portanto, se refere justamente a uma cultura préhispânica artificial, forjada para servir de souvenir a colecionadores. V e-se,

\footnotetext{
${ }^{109}$ Fuentes, Carlos. Los días enmascarados, Ediciones Era: México DF, 1988.

${ }^{110}$ Austín, Alfredo López e Luján, Leonardo López. Op. Cit, 2001.

${ }^{111}$ Idem.
} 
portanto, um rebaixamento da representação da morte que um dia o chacmool possa ter sido, representação essa da qual temos apenas fragmentos. No conto de Fuentes, a tradição literária representa o chacmool de forma contraditória, demonstrando a artificialidade a que é submetido com a tinta vermelha do vendedor de peças antigas, ao mesmo tempo em que lhe é dado um papel fantástico que nos remonta a personagens de contos de E.T.A. Hoffmann e Edgard Allan Poe ${ }^{112}$. Na fotografia de Rulfo, temos a figura emoldurada pelo enquadramento de uma câmera fotográfica que lhe tira a vida de maneira simbólica ${ }^{113}$, enlutando-a e, simultaneamente, recuperando-a através do artifício da modernidade que é a fotografia.

O que destacamos nesse momento, portanto, é a reminiscência do passado pré-hispânico mesclada à cultura ocidental, apesar da dura dominação europeia das Américas. Durante a Conquista, os espanhóis, seguindo os dogmas cristãos da época, subjugaram as culturas indígenas, rechaçando seus costumes e crenças, e buscaram sobrepor os seus próprios hábitos como os únicos possíveis. Implantaram a conversão compulsória dos índios que, ainda quando eram defendidos da violência a que eram acometidos, por freis como Montesinos e Las Casas, não tinham outra opção que a de "abandonar"114 suas crenças. O domínio espanhol, portanto, impôs aos indígenas uma nova forma

\footnotetext{
${ }^{112}$ Refiro-me a contos como "O homem da areia" e "Autômata", do alemão E.T.A. Hoffmann (1776-1822), e "O gato preto" e "O corvo" do estadunidense Edgar Allan Poe (1809-1849), contos de suspense, magia e terror que expressam a estética romântica de sua época. Rulfo, por sua vez, delimita o mistério de sua narrativa, como no conto "Macario" ou no próprio romance Pedro Páramo, em uma forma moderna. O substrato de um mundo noir e fantástico resiste, mas a forma de narrar, além da aliança do enredo a temáticas regionais, transformam o gênero. Hoffman, E.T.A. The best tales of Hoffmann. Nova Iorque: Dover Publications, 1967. Poe, Edgar Allan. Contos de Imaginação e mistério. São Paulo: Tordesilhas, 2015.

${ }^{113}$ Roland Barhes, Susan Sontag, Brassaï, entre tantos outros autores e fotógrafos reiteradamente associam o ato de fotografar à morte, como mencionaremos com mais detalhe a seguir.

${ }^{114}$ Aqui, entre aspas, pois sabemos que o abandono das crenças indígenas não se deu de maneira ideal e até hoje podemos ver manifestações das culturas nativas presentes por toda a América, ainda que de maneira marginal. Não entraremos nesse ponto, contudo, pois nos distanciaríamos demasiado de nosso objeto.
} 
de pensar e de interpretar o mundo conhecido, realocando os objetos a partir da disposição ditada pela nova cosmovisão cristã que os subjugou, obrigando-os a uma "invenção do mundo"115. Os espanhóis construíram seus templos, literalmente, sobre os antigos templos indígenas para simbolizar essa violência cultural. A majestosa Catedral Metropolitana, localizada no centro da Cidade do México, fora construída em cima de parte do antigo Templo Mayor, que teve como último líder Moctezuma. Porém, um processo de "transculturação", nos termos empregados por Ángel Rama ${ }^{116}$, desdobrou-se a partir desse primeiro contato e segue em desenvolvimento até os dias modernos. Entre as apertadas ruas ao lado do Palácio Nacional, que vão em direção à periferia da capital mexicana, é possível encontrar hoje altares feitos à Santa Muerte. Importante representante do sincretismo das religiões indígenas e espanhola, a devoção à Santa Muerte ${ }^{117}$ demonstra como, ainda que em meio à violência da conquista espanhola, a cultura mexicana autonomizou-se em relação à cultura de seu conquistador e transformou-se em uma terceira cosmovisão repleta dos matizes das culturas que a compõem.

Rama define o processo de transculturação como " $[u]$ n proceso en el cual emerge una nueva realidad, compuesta y compleja, una realidad que no es una aglomeración mecánica de caracteres, ni siquiera un mosaico, sino un

\footnotetext{
${ }^{115}$ O'Gorman, Edmundo. La invención de América. México D.F.: Fondo de Cultura Económica, 1995.

${ }^{116}$ Rama, Ángel. Transculturación narrativa en América Latina. Buenos Aires: Ediciones El Andariego, 2008.

${ }^{117}$ Esse sincretismo teve seus primeiros efeitos já na chegada dos espanhóis durante a Conquista. No que se diz respeito à morte, ela era um tema bastante popular na Idade Média, principalmente no século XIV quando da epidemia de peste negra. Ainda que a visão da morte se diferencie sobremaneira da visão pré-hispânica, como apontado anteriormente, o tema na cultura europeia já era muito frequente. Desse sincretismo que se prolongou até os dias atuais, tem-se, especialmente em povos do interior do sul mexicano, nos dias próximos ao(s) Día(s) de los muertos, o costume de erguer altares de vários degraus aos respectivos mortos da família. Nesses degraus, depositam-se aquelas que eram suas comidas preferidas em vida, confecciona-nos com seus retratos, e a imagem da Santa Muerte vela toda a composição. Tal ritual caracteriza a mencionada fusão da visão indígena da morte com a visão cristã-judaica inserida no continente após a Conquista.
} 
fenómeno nuevo, original e independiente ${ }^{\text {"118 }}$. É exatamente esse processo que observamos nas ruas da capital mexicana.

Portanto, além dos símbolos burlescos lembrados por Paz, a morte também é cultuada com solenidade no México. Para além da imagem institucional da morte como símbolo de uma identidade nacional, cuja celebração é animada e colorida, existe uma devoção à Santa Muerte, não reconhecida pela igreja católica, dominante no país, e um sentimento de luto nada diferente do que se repete ao redor do mundo ${ }^{119}$.

A partir desse rápido panorama é importante fazer uma observação sobre a "transculturação" latino-americana vinculada à representação da morte no México. Essa "transculturação" é bastante presente na literatura mexicana, como bem apontou Rama, para quem Juan Rulfo, através do laconismo de sua escritura, assim como Graciliano Ramos no Brasil e César Vallejo no Peru, realizou a "[r]earticulación global de la estructura cultural apelando a nuevas focalizaciones dentro de ella". Continua Rama, “[p]ara llevarlo a cabo es necesario una reinmersión en las fuentes primigenias. De ella puede resultar la intensificación de algunos componentes de la estructura cultural tradicional que parecen proceder de estratos aún más primitivos de los que eran habitualmente reconocidos. Estos ostentan una fuerza significativa que los vuelve invulnerables a la corrosión de la modernización”. Aproveitando o vocabulário do próprio Rama, aquelas "focalizações” também se darão pelas lentes das câmeras de Rulfo. A "fuente primitiva" está presente na fotografia

118 Rama, Ángel. Transculturación narrativa en América Latina. Buenos Aires: Ediciones El Andariego, 2008, p. 40, nota 21.

${ }^{119} \mathrm{O}$ costume das plañideras, registrado na Espanha desde a Idade Média, se vê também em cidades do sul do México, onde mulheres se reúnem em funerais para "chorar o morto", enquanto os homens tomam bebidas alcoólicas relembrando eventos notáveis da vida daquele por quem velam. No interior do Brasil, em especial no interior de Minas Gerais, se cantam as "inselências" à cabeça do defunto. 
do chacmool e em tantas outras em que Rulfo focaliza as ruínas de ídolos préhispânicos, e está presente também em Pedro Páramo, em que podemos notar os signos que se referem à cultura pré-hispânica. A morte nesse meio, é uma figura híbrida marcada pela reminiscência da fonte primitiva e pela transculturação resultante da sobreposição cultural ocorrida na América Latina. É um conceito de difícil discursivização, assim como o discurso que Juan Rulfo constrói em sua narrativa a partir desse tema.

A visão da concepção da morte como um elemento atravessado por diversos discursos e distintas cosmogonias que se contradizem e se complementam pode ser vista de uma forma quase material pelas ruas da Cidade do México. A disposição dos elementos de cada um dos matizes culturais na região central da capital mexicana, as ruínas indígenas soterradas pelas construções espanholas e os altares à Santa Muerte nas esquinas das ruas que seguem do centro à periferia, esboçam uma figura que deve ser vista em sua totalidade e que, com cada uma de suas partes, forma um todo complexo que é a transculturação mexicana e a representação da morte no país. A disposição de cada um desses elementos culturais demonstra ainda um esforço político de (re)alocá-los na sociedade conquistada, porém o resultado é uma imagem sem centro, cujas partes representam diferentes momentos históricos do país. Como em uma fotografia, esses momentos se revelam simultaneamente. ${ }^{120}$

\footnotetext{
${ }^{120} \mathrm{Em}$ relação a isso, é interessante notar as fotografias do Castillo de Teayo, localizado no centro da cidade de mesmo nome, na região de la Huasteca, estado de Veracruz, retiradas para o programa Google Street View. Em frente ao monumento, um senhor com chapéu observa o provável carro da empresa norte-americana que fotografa a região. Se girarmos a imagem em $180^{\circ}$, vemos que, de frente para o monumento mexica, há uma feira com várias barracas, uma cantina ou fonda com propagandas da cerveja Corona e várias pessoas que, da mesma forma que o senhor do outro lado da rua, na praça do castelo, observam aquela ação da empresa estadunidense na pequena cidade. Entre essa curiosa dinâmica, ergue-se o monumento indígena, dando mais um tom transcultural à cena aí perpetrada.
} 


\section{A morte na fotografia}

Muitos fotógrafos, mexicanos ou não, revelaram em suas imagens cenários em que se exibem os distintos tempos referentes à antiga cultura préhispânica e à cultura europeia, apresentados simultaneamente no México, em especial na primeira metade do século $\mathrm{XX}$. Assim trabalharam vários fotojornalistas, como os irmãos Augustín e Miguel Casasola (ainda no final do século XIX), e Nacho López e, num âmbito artístico, Tina Modotti e Manuel Álvarez Bravo. As fotografias de Juan Rulfo também revelam essas imagens, principalmente nas imagens dasruínas de construções que se encontram no interior do país. A simultaneidade entre cultura pré-colombiana e cultura criolla são evidenciadas por Juan Rulfo fotógrafo.

Além da questão temática, há um vínculo formal entre a morte e a fotografia que se esboça no próprio exercício de usar a câmera fotográfica. $\mathrm{O}$ escritor-fotógrafo, além de apresentar a temática da morte em seus escritos, manejou o aparato fotográfico que situa a morte como um dos símbolos-chave para a sua análise segundo alguns grandes teóricos que se empenharam nesse labor. Sob a égide da morte como elemento auxiliar na análise da imagem visual, o aparato fotográfico, quando se volta a todos aqueles elementos heterogêneos presentes no México submete-os a um único aniquilamento.

Roland Barthes, em Câmera clara $^{121}$, afirma que os retratos são reveladores da face imóvel da morte, pois mostram não o que o modelo era no momento em que foi fotografado, mas seu spectrum. A foto de Napoleão

\footnotetext{
${ }^{121}$ Barthes, Roland. Câmera clara: notas sobre fotografia. Rio de Janeiro: Editora Nova
} Fronteira, 1984. 
Bonaparte mencionada por Barthes logo no início de seu ensaio não lhe atualiza a pessoa de Napoleão, tampouco leva o espectador àquele tempo passado em que a presença do líder francês se fez passível de ser capturada pelas lentes de uma câmera. Napoleão simplesmente não está ali, não é aquele do momento da foto, tampouco aquele que se vê desde o presente de Barthes. O que vislumbra Barthes é o spectrum do líder francês. O discurso que inclui a figura de Napoleão fotografado está permeado por tempos que se mesclam, passado e presente, e posicionam a figura em um terreno insólito para a sua descrição. Essa imagem não responde à pergunta sobre quem era Napoleão, mas faz parte da construção de uma possível resposta. Como dito no capítulo anterior, a fotografia não é a história, mas, e adiantando nosso próximo capítulo, é um dos documentos que servem para apontar a existência de uma história, e pode ser a simulação de uma resposta que, de fato, em momento algum poderá ser expressa.

Essa resposta à pergunta “quem era Napoleão?”, ou tentativa de resposta, através da fotografia, se dá a partir da morte. Em outras palavras, o que chamamos de resposta é a narrativização da fotografia. Ao afirmar sobre a construção de respostas, nos referimos à possibilidade de a fotografia se fazer narrativa, ainda que essa narrativa fuja do que é a fotografia, imagem visual por excelência e, por isso, a "resposta" nunca é plena. A morte, portanto, é uma chave para essa narrativização.

No ensaio de Barthes, a revelação de Napoleão em objeto fotográfico, ou do próprio Barthes quando se imagina fotografado, transforma-os na própria morte: "mas quando me descubro no produto dessa operação [fotográfica], o 
que vejo é que me tornei Todo-Imagem, isto é, a Morte em pessoa"122 escreve Barthes. Segue o autor: "[n]o fundo, o que encaro na foto que tiram de mim (a 'intenção' segundo a qual eu a olho) é a Morte: a Morte é o eidos dessa Foto" ${ }^{123}$ (grifos do autor). A morte é o ponto inicial para a análise da imagem fotográfica no ensaio barthesiano ${ }^{124}$. É a partir dela que se permite a estagnação dos objetos na imagem, a análise minuciosa de seus detalhes, o descobrimento do punctum, elemento que altera a percepção do conteúdo imagético, e, de certa forma, conforma ao espectador a irrealidade do objeto fotográfico que tem sob seus olhos. A morte fotográfica aponta para o espectador que a imagem não é a realidade.

Todas as fotografias, nos termos apontados por Barthes, carregam em si algo de fantasmal devido ao spectrum que surge quando da morte dos objetos fotografados. $^{125}$

Fantasmais também são as fotografias para Robert Castel, quando menciona seu poder de realocar a realidade na psique de certos espectadores. ${ }^{126}$ Castel se detém em um fenômeno contrário ao observado por Barthes enquanto espectador das imagens fotográficas. O espectador de Castel não aceita a morte na fotografia, não percebe o caráter espectral de seus objetos fotográficos, e os tem como entes vivos, feitos da sua mesma matéria. Para o observador de Castel, uma foto de Napoleão diz quem era Napoleão, ou melhor, quem é

\footnotetext{
${ }^{122}$ Barthes, Roland. Op. Cit, p. 28.

${ }^{123}$ Ibidem, p. 29

${ }^{124} \mathrm{~A}$ presença da morte em Câmera clara não se refere apenas ao postulado em relação ao ato fotográfico, mas também a um dado biográfico que no decorrer do ensaio servirá a Barthes como guia para suas análises, ao mencionar uma foto antiga de sua mãe recém-falecida. Paralelamente à escrita de Câmera clara, Barthes também escreveu Diário de luto (2010), livro de memórias em que o autor constrói o trabalho de luto frente à perda de sua mãe e a necessidade de seguir com a escrita do livro de ensaios sobre a fotografia.

${ }^{125} \mathrm{E}$, por isso, toda imagem é uma narrativa, como afirmara o próprio Barthes em Elementos de Semiologia. Op. Cit.

${ }^{126}$ CASTEL, Robert. "Imágenes y fantasmas". In: Bourdieu, Pierre. La fotografía: un arte intermedio. México D.F.: Editorial Nueva Imagen, 1979.
} 
Napoleão, pois o personagem é atualizado e eternizado na imagem que detém em mãos. A forma como se relaciona com as imagens faz com que esse espectador tenha respostas imediatas às perguntas em relação ao que vê, porém sua percepção da realidade na imagem o converte em um enfermo. A mediação da imagem é desconsiderada, a fotografia se converte em história e os discursos verbais são imprecisos frente à imagem.

A enfermidade psicológica referente à destruição da mediação da imagem e sua substituição pela realidade é recorrente na literatura. Edgar Allan Poe narra no conto "O retrato oval" a história de um pintor que se dedica arduamente a produzir um retrato fiel de sua amada, chegando mesmo a afirmar que sua pintura era a própria vida, sem perceber que sua modelo morria diante da produção do retrato. Em "A caçada" de Lygia Fagundes Telles, a imagem de um caçador bordado em uma velha tapeçaria é responsável pela imersão de seu observador na caça ali representada, borrando os limites da realidade e da imagem. Em um caso parecido, no famoso conto de Julio Cortázar, "Las babas del diablo", o fotógrafo Michel se vê consumido pela imagem que ele mesmo produzira, pendurada na parede de seu escritório, e não deixa de relacionar aquela imagem com a sequência de eventos inusitados que se seguiram após sua tomada, além de revivê-los ao observar aquela "mágica" fotografia de um casal em um parque de Paris. Nos três contos referidos, a sanidade mental dos personagens pode ser contestada de acordo com as postulações de Castel. Se os vemos como enfermos da patologia do sociólogo francês, esses personagens já não distinguem a realidade da imagem. O que têm frente a si são fantasmas e com esses lidam. 
Em Pedro Páramo, Juan Preciado, acometido pelos murmúrios de Comala, asfixiado pelo calor e pela falta de ar da cidade, pergunta a Donis e sua irmã: "[n]o están ustedes muertos?",127. Ao que respondem os personagens:

“- Está borracho - dijo el hombre.

- Solamente está asustado - dijo la mujer.,"128

O fato de não poder diferenciar a vida da morte leva os irmãos a tratar Preciado por ébrio, ou seja, com a percepção alterada, ou como alguém com um medo quase patológico que o impede de perceber a realidade. ${ }^{129}$ Em Pedro Páramo, o medo toma conta de Juan Preciado e não apenas o impede de discernir com clareza o que o rodeia como, segundo muitos críticos, também é o principal responsável pela sua morte. Diferente dos personagens dos contos antes mencionados, porém, Preciado não está diante de imagens. Os irmãos incestuosos são descritos em completa corporalidade, seus corpos se impregnam nos fragmentos em que estão presentes, retomando de perto o exposto por Bakhtin em relação aos corpos grotescos, que são referidos por suas secreções, seu sexo e seus orifícios. A irmã de Donis, além de contar sobre o ato sexual incestuoso praticado, tem o corpo descrito como "hecho de tierra, envuelto em costras de tierra, se desbarataba como si estuviera derretiéndose como em un charco de lodo". E sobre as secreções desse corpo,

\footnotetext{
${ }^{127}$ Pedro Páramo, p. 107

${ }^{128}$ Ibidem. p. 107.

${ }^{129}$ Em uma obra bastante distante e conhecida como a fundadora do romance moderno, a sensação de medo também é apontada como a responsável pelos enganos da mente. Em uma passagem de Dom Quixote de la Macha há uma referência bastante interessante a respeito dos efeitos do medo na percepção. O protagonista diz ao temeroso Sancho Pança na primeira parte do clásico español: “(...) uno de los efectos del miedo es turbar los sentidos y hacer que las cosas no parezcan lo que son". Cervantes, Miguel de. Don Quijote de la Mancha. Parte I, Capítulo 18. s/d.
} 
Preciado ainda afirma: "[y]o me sentía nadar entre el sudor que chorreaba de ella ${ }^{130}$. Seus extremos corporais, dedos e pés, parecem mais relevantes do que o seu rosto, que Preciado nota apenas tratar-se de "una cara común y corriente" 131 . Entretanto, ainda que esteja de frente à "realidade" desses corpos, ao realismo grotesco, a situação psicológica de Preciado o impede de interpretá-los, o medo é continuamente mencionado nos fragmentos que se referem ao casal de irmãos, o que também antecipa a fatalidade que mais adiante será revelada. Afinal, Preciado já não distingue bem vivos de mortos porque após deparar-se com uma série de mortos, torna-se aos poucos, ele também, um defunto. Juan Preciado está, portanto, diante da imagem da morte.

Em um fragmento em que uma imagem fotográfica é explicitamente citada no romance, Preciado, no início de sua viagem, retira um retrato de sua mãe de dentro do bolso da camisa ${ }^{132}$. Preciado não tem nenhuma dúvida quanto à representação da realidade presente na fotografia que maneja, em momento algum essa fotografia se converte na mãe morta, porém na descrição que faz do retrato levanta considerações muito importantes acerca da realidade do objeto que carrega consigo. O único retrato que a mãe teria deixado fazer-se de si, pois acreditava que "los retratos eran cosas de brujería", está "carcomido en los bordes" e "lleno de agujeros como de aguja, y en dirección del corazón

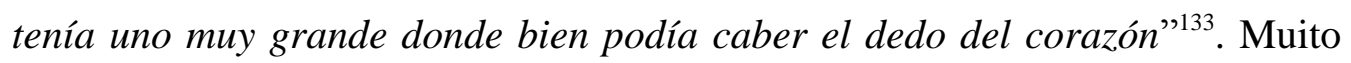
desprende-se dessa rápida menção à fotografia, única em toda obra narrativa do autor.

\footnotetext{
${ }^{130}$ Pedro Páramo. pp. 116 e 117.

${ }^{131}$ Idem. p. 111.

${ }^{132}$ Essa passagem fora citada no capítulo anterior, em que analisávamos o tempo atuante na imagem fotográfica e realizávamos uma comparação com a memória, citando Juan José Saer em seu romance Glosa (1986).

${ }^{133}$ Pedro Páramo. p. 68
} 
Primeiro, faz-se notar a crença da fotografia como um objeto mágico.

De acordo com a história da imagem rapidamente esboçada por Villém Flusser em Filosofia da Caixa Preta ${ }^{134}$, o surgimento da escrita marca na história da humanidade a transformação da visão mítica do mundo em uma visão linear e cronológica. O retorno da imagem em forma de imagem técnica no século XIX, por sua vez, aponta o fracasso do texto na sua tarefa de auxiliar o homem a compreender seu entorno. Mas, segue o filósofo, essas imagens técnicas não são mais vistas como ferramentas mágicas que mediam a representação do mundo, como eram as imagens pré-históricas. A tarefa imaginativa é problematizada nas imagens técnicas porque a imagem é vista como a própria realidade e não como seu símbolo imaginativo.

Nota-se que Flusser não levou em consideração a escrita poética, que não segue rigidamente a linearidade forjada pelo discurso histórico, científico e explicativo, mas segue os passos das imagens poéticas para sua composição. O romance de Juan Rulfo seria um dos seus melhores exemplos. ${ }^{135}$ Completamente alheia à linearidade e apegada a um discurso cuja sintaxe busca construir essas imagens poéticas, a narrativa de Rulfo é “linealidad y profundidad, sintagma y paradigma, sintaxis y magia, esto último en el sentido empleado por él [Flusser]"136. A magia está presente tanto na escrita rulfiana quanto na imagem segundo os termos de Flusser. E no momento em que a narrativa rulfiana se refere ao retrato, a questão da magia é novamente

\footnotetext{
${ }^{134}$ Flusser, Vilém. Hacia una Filosofía de la Fotografía. Trad. Eduardo Molina. Edição 1. México, D.F: Editorial Trillas, 1990.

${ }^{135}$ Tal fato fora notado por Alberto Vital, quem analisa comparativamente a escrita de Juan Rulfo e de Rainer Maria Rilke. Ao aproximar a escrita de Rilke à de Rulfo, nota que elas não são lineares, mas estão compostas por uma dimensão da escrita não observada por Flusser: a da imagem poética. Vital parte da aproximação entre o poeta alemão e o escritor mexicano devido, também, ao fato de que Rulfo traduzira os poemas de "Elegias de Duino" de Rilke. Em: Vital, Alberto. Rilke, Rulfo. México: Samsara, 2012, p. 33.

${ }^{136}$ Vital, Alberto. Op. Cit. p. 33
} 
reiterada. Afinal, de fato, como se estivesse sob o efeito de um vudu maligno, Dolores Preciado sofrera quando viva nas mãos de Pedro Páramo. Não a toa seu nome se refere às dores (dolores) de que padecera, simbolizadas no retrato pelos buracos que o deterioraram.

O segundo fato que se destaca da menção desse retrato, e que deriva do primeiro, é a presença da morte na imagem. A mãe de Preciado está morta, e é devido à promessa feita em seu leito de morte que o personagem empreita a viagem à Comala. Carregando o retrato no bolso de sua camisa, Preciado não leva unicamente uma espécie de retrato vivo de uma pessoa que já morreu, mas leva, também, a morte impregnada nesse objeto mágico capaz de matar as coisas sobre as quais recaíram as lentes que os retiveram em um determinado momento. Sem saber, Juan Preciado carrega duas mortes ao entrar em Comala e, assim, encomenda uma terceira, a sua própria. O deterioro físico do suporte fotográfico cria uma imagem em mis en abyme: a mulher fotografada está morta, o retrato mata a mulher fotografada, o tempo "mata" o suporte físico da imagem ${ }^{137}$. Não somos informados, em Pedro Páramo, de que enfermidade teria padecido Dolores Preciado, porém o caráter fatal de seu único retrato denuncia que seu padecimento era inevitável.

Da mesma forma como sugerimos na análise dessa passagem de Pedro Páramo, o ato de fotografar tem sido reiteradamente associado ao ato de tirar vidas. Susan Sontag, em seu Sobre fotografia ${ }^{138}$, menciona a agressividade e a violação de que é capaz de cometer a fotografia sobre o objeto ou pessoa fotografada, mesmo sob a passividade de um fotógrafo que manipula sua máquina com distração. Afirma que a fotografia é um “(...) [a]ssassínio

\footnotetext{
${ }^{137}$ Como mencionado no capítulo anterior, em que nos voltamos à análise do tempo que corrói o material físico da fotografia.

${ }^{138}$ Sontag, Susan. Op. Cit.
} 
sublimado, suave, digno de uma época triste e assustada"139. Relacionando esse caráter psicopata da fotografia com o caso de Lady Di, ainda afirma, como assinalou também o fotógrafo húngaro Brässai ${ }^{140}$, que a fotografia é memento $\operatorname{mori}^{141}$.

Por sua parte, José Wenceslau Caminha Aguiar Júnior ${ }^{142}$ cita vários exemplos em que a fotografia é vista como um objeto fatal, comparando o fotógrafo a um “caçador invisível”. Cita a crendice popular em que indígenas teriam medo do aparato fotográfico e não se deixariam fotografar por crerem que a fotografia roubar-lhes-ia suas almas. Segue mencionando que, para um povo de Chiapas, ao sul da capital mexicana, a cada retrato tomado de um indivíduo, uma de suas treze camadas de alma é sugada, fato que se assemelha ao dito por Honoré de Balzac, no século XIX, sobre a fotografia, mencionado pelo fotógrafo francês Félix Nadar:

““(...) o dito corpo, a cada nova operação [fotográfica], sofre a perda evidente de um espectro, ou seja, uma parte de sua essência constitutiva",143.

No filme Blowup (1967), também citado por Aguiar Jr., do diretor Michelangelo Antonioni e inspirado no conto mencionado anteriormente de Cortázar, "Las babas del diablo", é a partir de uma fotografia que o

\footnotetext{
${ }^{139}$ Sontag, Susan. Op. Cit, p. 23.

140 Leite, Miriam Lifchitz Moreira. “As transformações da imagem fotográfica”. In: Revista de Antropologia vol.41 n.2 São Paulo1998 ISSN 0034-7701 [on-line] 05/06/2014 Disponível em <http://www.scielo.br/scielo.php?script=sci_arttext\&pid=S0034-77011998000200001>.

${ }^{141}$ Sontag, Susan. Op. Cit., p. 24

${ }^{142}$ José Wenceslau Caminha. "O caçador invisível". In: Anais do $20^{\circ}$ Encontro Nacional. Da Associação Nacional de Pesquisadores em Artes Plásticas. 2011. [on-line] 26/05/2014. Disponível em <http://www.anpap.org.br/anais/2011/pdf/chtca/jose_wenceslau_aguiar_junior.pdf > .

${ }^{143}$ Nadar, Teoria dos espectros apud Krauss, O fotográfico apud Aguiar Jr, José Wenceslau Caminha. Op. Cit.
} 
protagonista descobre um crime. Ao mesmo tempo em que disparara sua câmera, alguém dispara uma arma contra um homem, observado pela mulher assustada flagrada pela objetiva.

Em Peeping Tom (1960), de Michael Powell, o fotógrafo mata suas amantes depois de fotografadas. Para retornarmos à literatura, outro exemplo relevante para a analogia entre o ato fotográfico e a morte é o poema que Charles Baudelaire dedica ao já citado Félix Nadar em As Flores do Mal. "O Sonho de um Curioso", encontrado na parte da obra destinada à temática da morte, apresenta um eu-lírico que, após ter seu retrato tomado pelo fotógrafo, diz "'étais mort sans surprise, et la terrible aurore / M'enveloppait. (...)" (Eu morrera sem susto e já me rodeava / A terrível aurora (... $)^{144 »,}$

Para encerrar a abundante sequência de exemplos que citam a relação fotografia/assassinato, vale incluir a fala de um importante fotógrafo da Guerra do Vietnã. É justamente na guerra que a morte na fotografia se destaca como um mis em abyme, a morte que impõe o aparato fotográfico aos seus objetos fotografados dialoga diretamente com as cenas de morte convertidas em fotografias.

Eddie Adams, fotógrafo estadunidense, em entrevista para a revista Time na ocasião da conquista do prêmio Pulitzer de fotografia, em 1969, afirmou: "The general killed the Viet Cong; I killed the general with my camera" $^{145}$. O prêmio lhe fora concedido devido a uma foto em que flagra o momento em que um general atira na cabeça de um vietcongue. Igualmente, foi durante a Guerra Civil Espanhola que Robert Capa realizou sua célebre fotografia denominada "Morte de um miliciano", em que um miliciano é

\footnotetext{
${ }^{144}$ Baudelaire, Charles. As flores do mal. Versão bilíngue. s/d.

145 "O general matou o vietcongue; eu matei o general com minha câmera”, tradução nossa.
} 
supostamente baleado. Esta última foto, contudo, tem sido continuamente acusada de ser uma encenação. Tal fato, porém, não diminui nosso argumento. Tanto em Capa quanto em Adams, o que se vê é um duplo aniquilamento: aquele cometido na guerra, o referencial e aquele imposto pela câmera fotográfica aos seus objetos e atores fotográficos, o "mágico". Ao pronunciar as palavras citadas à revista Time, Adams não percebera que, quando "atira" a sua câmera para a cena da morte do vietcongue, ele próprio mata o vietcongue por uma segunda vez.

O discurso científico que realoca a fotografia no âmbito da técnica opõe-se à visão da fotografia de acordo com as postulações de Barthes, que vê no retrato sua própria morte, e de Adams, que vê em seu ato de fotografar a possibilidade de "vingar" a morte do vietcongue assassinado. O processo químico que envolve a revelação fotográfica forma parte de um discurso explicativo completamente oposto aos discursos anteriores. A luz é a responsável pela visualização dos objetos anteriormente expostos às lentes da câmera fotográfica. Nada alterou o estado daqueles objetos fotografados, apenas a luz fora apreendida pela placa metálica e transformada em uma imagem visível ${ }^{146}$. Mais uma vez, a oposição entre um discurso explicativo e um discurso "mítico" é produzida. A fotografia, portanto, está permeada por um discurso científico, que inclui a explicação química de sua revelação e, por outro lado, pelo que chamaremos de "discurso poético do processo fotográfico", onde se presentifica a morte do objeto fotografado ${ }^{147}$.

\footnotetext{
146 Esse processo se refere às antigas câmeras fotográficas analógicas, como a Rolleiflex, utilizada por Juan Rulfo. O processo das câmeras digitais, porém, não se afasta muito daquele, pois a luz ainda é determinante para a produção das imagens, que agora podem ser produzidas às centenas com muito mais rapidez.

147 Susan Sontag menciona o caráter de "ficção-científica psicológica" presente neste segundo nível de compreensão da imagem fotográfica apontado por nós: "Numa ponta do espectro, as
} 


\section{A morte na fotografia de Rulfo}

O discurso poético do processo fotográfico aproxima a fotografia da visão mágica da imagem, tal como vimos quando comentamos as postulações de Flusser. A magia da fotografia recairia sobre o ato do aniquilamento que impõe aos seus objetos fotografados. Nesse âmbito, o diálogo entre fotografia e morte, citado em obras literárias como uma metáfora bastante produtiva pode ser muito propício para a análise dos mundos rulfianos, tanto na esfera fotográfica quanto na narrativa, pois uma vez que optamos por este segundo discurso da fotografia, o não técnico, aproximamo-nos da estrutura narrativa do romance de Rulfo. Em toda a sua obra escrita vê-se uma grande resistência aos discursos lineares e explicativos ${ }^{148}$.

Os personagens de Rulfo vivem em uma realidade em que o discurso do Estado, das leis, da física e da química estão problematizados. Em "Luvina", os passos de velhas mulheres tem som de asas de morcegos, em "Nos han dado la tierra", a palavra do Estado não condiz com a realidade encontrada pelos campesinos à procura de terra, em Pedro Páramo os documentos que legislam sobre as propriedades de terras de Comala não servem para afastá-las do cacique Pedro Páramo. Seja por estados alterados

fotos são dados objetivos; na outra, são elementos de ficção científica psicológica". Sontag, Susan. Op. Cit. p. 179.

${ }^{148}$ Por esses discursos levamos em consideração o que Roberto González Echevarría afirma sobre os "discursos hegemônicos", que seriam aqueles relacionados à ciência e à lei, intrínsecos aos primeiros textos narrativos latino-americanos: "La historia y la ficción latinoamericanas, la narrativa de América Latina, fueron concebidas al principio en el discurso de la ley, una totalidad secular que garantizaba su veracidad y hacía su circulación posible" (2011:41) e sobre os romances do século XX, afirma: "que fueron resultado de la relación con el discurso hegemónico del periodo, que no fue literario sino científico" (2011:43). Dessa forma, percebemos que Rulfo buscou suas bases em um discurso que questiona aquele que era predominante, segundo Echevarría. Voltaremos a este tema quando nos refiramos aos murmúrios dos mortos em Pedro Páramo. 
de percepção (em "Luvina", o narrador está em um bar, possivelmente ébrio), seja pelo poder de que usufruem alguns (em "Nos han dado la tierra" e em Pedro Páramo os personagens estão submetidos a um poder que está acima das leis), o "discurso hegemônico" é questionado.

Dada a problematização do discurso hegemônico, o discurso que se impõe e se mescla a ele, especialmente em Pedro Páramo, é o da morte, que não pode se dar nos termos de um discurso científico. Não é a morte biológica que vemos descrita no romance. A decomposição dos corpos mencionada por Dorotea se conjuga com a capacidade de os cadáveres, enterrados, poderem murmurar suas lembranças. São os mortos que guardam e murmuram a história de Comala; é a partir de lembranças e de discursos problematizados, vindos do espaço da morte, que se pode reconstruir a história da cidade.

Roberto González Echevarría afirma que a morte “(...) es el tropo estructurador del principio del Archivo" $"$ ". Por sua vez, a partir de textos de Freud, o francês Jacques Derrida (2005) percebe o "mal do arquivo" como fruto da pulsão de morte advinda das forças de uma instituição de poder causadora da repressão que se imporia sobre aquele arquivo ${ }^{150}$. Rulfo, em seu romance, leva às últimas consequências essas concepções, pois o arquivo do povo de Comala, representado pela memória de seus habitantes, sofre com o poder negligente de Pedro Páramo, quem abandona a cidade à morte:

\footnotetext{
“Juró vengarse de Comala:

- Me cruzaré de brazos y Comala se morirá de hambre.
}

\footnotetext{
${ }^{149}$ Echevarría, Roberto González. Op. Cit.

${ }^{150}$ Em: Derrida, Jacques. Mal do arquivo, uma impressão freudiana. Rio de Janeiro: Dumará,
} 2005. 
Porém, no momento em que estrutura a história nesses murmúrios fantasmais, Rulfo desestrutura o arquivo, dá-lhe um formato quase impossível. O "arquivo", registro memorialístico dos eventos de Comala, é composto a partir da morte. Para compreendê-lo parece indispensável compreender o que é essa morte que padece toda população daquela cidade. Em um texto presente em Los cuadernos de Juan Rulfo ${ }^{152}$, em que se publicam rascunhos de contos e romances apontados pelo escritor e nunca publicados em vida, denominado "Después de la muerte", um personagem já morto discorre sobre esta condição :

\author{
"La muerte es inalterable en el espacio y en el tiempo. \\ Es sólo la muerte, sin contradicción ninguna, sin \\ contraposición con la nada ni con el algo. Es un lugar donde \\ no existe la vida ni la nada",153.
}

A noção da morte está formada pelas negações de outros conceitos repletos de significados opostos. O narrador joga com os pressupostos culturais e religiosos do leitor para logo negá-los. Uma vez que é forçado a abandonar seus pressupostos, o leitor se depara, contudo, com um vazio ${ }^{154}$. A definição da

\footnotetext{
${ }^{151}$ Rulfo, Juan. Los cuadernos de Juan Rulfo. México D.F.: Ediciones Era, 1996. p. 171.

${ }^{152}$ Ibidem.

${ }^{153}$ Idem.

${ }^{154}$ Aqui, "pressupostos" têm o valor do conceito de "supuestos" mencionado por Huamán. Assim o define:
}

“a) implicaciones contextuales (supuestos que el individuo deriva al combinar la nueva información con otras que ya tenía).

b) Reforzamientos o incrementos del grado de certeza que un individuo asigna a un supuesto.

c) Eliminaciones de supuestos que entran en contradicción con la nueva información." 
morte nas obras de Rulfo é sondada através da sua própria composição: na fotografia, podemos buscá-la no processo fotográfico, na narrativa, na estrutura do texto. Na fotografia, portanto, a noção da morte dialoga com o que expusemos sobre a poética do processo fotográfico, que aniquila os objetos da imagem; na escritura, a noção da morte dialoga com a estrutura que foge da linearidade e do realismo. Juan Rulfo, a exemplo do que afirma Octavio Paz sobre o poema ${ }^{155}$, utilizou a linguagem visual e escrita para mencionar a inexplicável, mas não ininteligível, experiência da morte.

Em sua fotografia, diferente de Manuel Álvarez Bravo, um dos mais célebres fotógrafos mexicanos, quem chegou a mirar suas lentes em direção a um cadáver na fotografia "Obrero en huelga asesinado", de 1934, Rulfo não tematiza a morte de uma maneira realista. Em certa ocasião, afirmou que não contribuiria, em sua literatura, com mais gotas de sangue. Suas fotografias, ainda com maior sucesso que sua narrativa onde se presentificam várias cenas de violência, segue mais à risca essa vontade. Contrário às inúmeras imagens de corpos e sangue presentes até hoje nos jornais mexicanos, a morte na fotografia de Rulfo é tematizada de maneira poética e em consonância com outras questões caras ao artista.

As fotografias de Rulfo tampouco apresentam o pessimismo que os contos de El llano en llamas e o romance Pedro Páramo oferecem ao leitor. Não são os objetos sobre os quais recaem suas demoradas lentes que emanam a negatividade da sua fotografia. Ainda quando tematiza a passagem do tempo, fá-lo de maneira contemplativa. É na câmera escura que se revela,

Em: Huamán Villavicencio, Miguel Ángel. "Elementos de pragmática de la comunicación literaria”. In: Lecturas de Teoría Literaria II. Lima: UNMSM, Fondo Editorial, 2003.

155 "El poema es inexplicable, no ininteligible". Paz, Octavio. "Recapitulaciones". In: Obras completas I: La casa de la presencia. Poesía e historia. México D.F.: FCE, 1994. 
ironicamente, o lado terminantemente negativo das suas fotografias. A revelação do negativo impregna a negatividade da morte expressada de acordo com os termos barthesianos. Portanto, é no processo que envolve o fazer fotográfico que podemos inserir as fotografias de Rulfo na temática da morte. Sobre esse assunto, Philippe Dubois afirma que “(...) qualquer fotografia, no momento que é feita, remete para sempre seu objeto ao reino das sombras" ${ }^{156}$. Os indígenas, os campesinos, os amigos pessoais de Rulfo, sua amada Clara Aparicio, e o próprio Rulfo, todos personagens das suas fotografias, estão, sob suas próprias lentes, condenados ao mito de Orfeu, petrificados para sempre na morte da fotografia.

Na fotografia do Santuário de Ocotlá, em Tlaxcala, Rulfo registra sua sombra, que se esparrama na parte inferior da foto frente ao templo iluminado pelo sol, separado da sombra do fotógrafo por uma muralha formada por três pontas triangulares. A sombra que emana do fotógrafo revela o lado negativo do templo que se ergue no centro da imagem, iluminado e suntuoso. Através da câmera do fotógrafo, o santuário é enviado para aquele reino sombrio mencionado por Dubois, reino anunciado pela sombra do fotógrafo, aquele que tem a "chave" para esse reino. O templo não passa da reminiscência do templo real, a imagem é um truque, o que se vê pleno e iluminado é, na verdade, a imagem da sombra e da morte.

\footnotetext{
${ }^{156}$ Dubois, Philippe. O ato fotográfico, Campinas/São Paulo: Papirus, 1993, p. 312 apud Aguiar Jr, José Wenceslau Caminha, Op. Cit.
} 


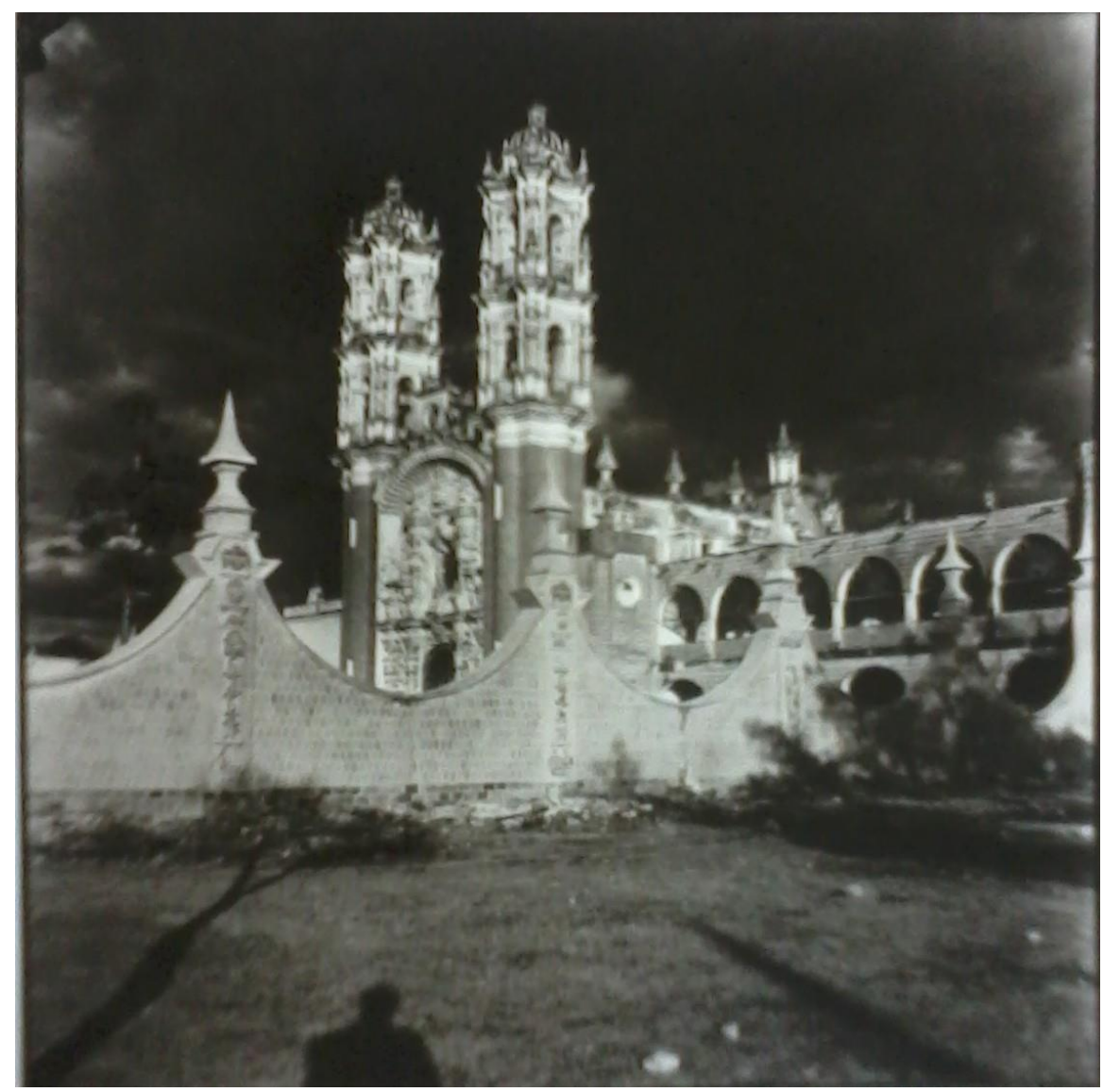

Figura 7 - Juan Rulfo, Santuário de Ocatlán em Tlaxcala, s/d.

Apesar da ausência da morte como temática explícita na fotografia rulfiana, em outra de suas fotos podemos perceber, além da já mencionada intersecção das culturas europeias e pré-hispânicas, uma tematização indireta da morte, construída por nossos olhares que percorrem a imagem de uma mulher que atravessa um chão de azulejos em formato de tabuleiro com um cesto apoiado na cabeça. Ao fundo da imagem se identifica, no topo de um morro, a igreja de Santa Prisca, em Taxco, estado de Guerrero. A figura da mulher se apequena em comparação com as proporções da igreja e do grande "tabuleiro" aos seus pés. Esmiuçada na cena, carrega o cesto que curva seu corpo junto com a ostentação do resto da paisagem. A mulher parece martirizada pelo seu trabalho, como, segundo a tradição cristã, ocorrera com a 
santa que dá nome à igreja. Quase na mesma horizontal da mulher, na extrema esquerda, um farol pende de uma parede de pedra, como se estivesse vigiando o caminhar da moribunda.

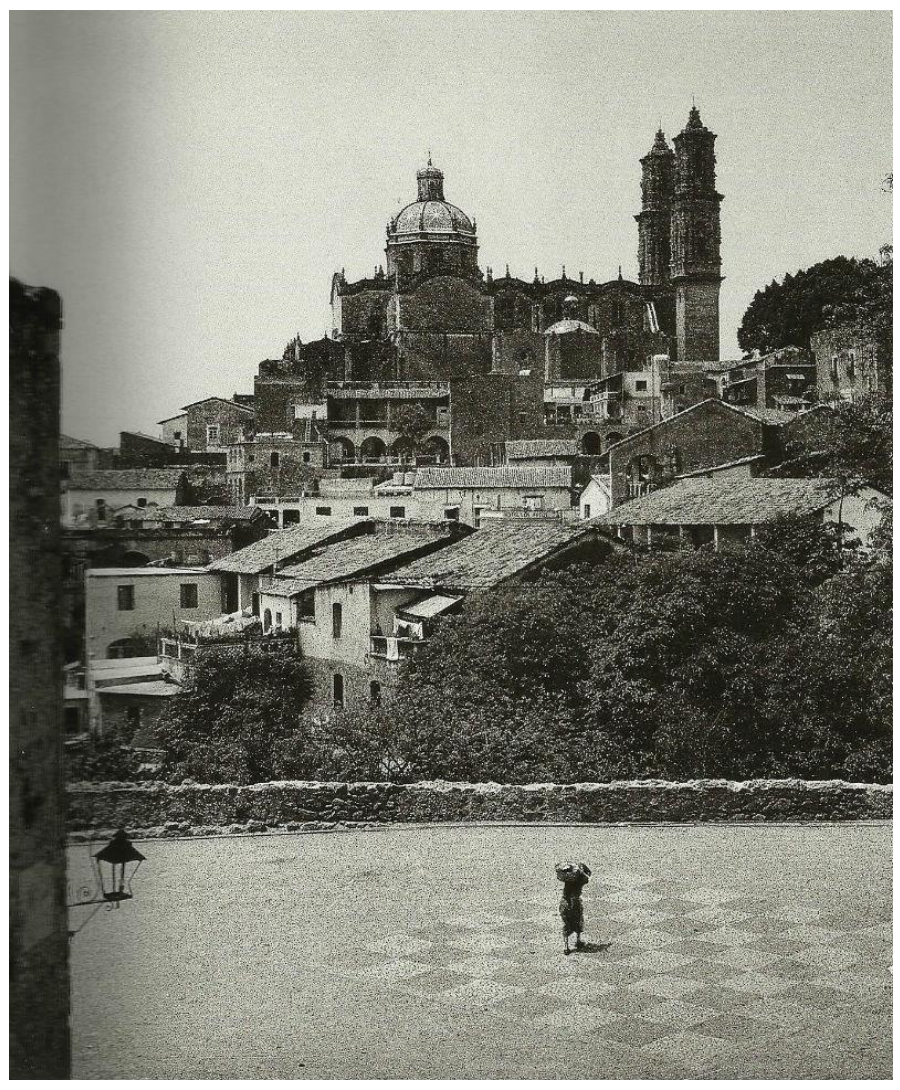

Figura 8 - Juan Rulfo, Igreja de Santa Prisca em Taxco, 194-.

Nessa fotografia, o "tabuleiro" aos pés da mulher dialoga com algumas representações medievais da morte, em que esta, personificada, joga com os humanos através do xadrez, apostando a vida daquele que a desafia. Essa é a visão da morte que perdurou durante a Idade Média europeia e que se impôs no continente americano corroborada pela contrarreforma instaurada pelo Concílio de Trento durante os primeiros anos da Conquista ${ }^{157}$. A morte é o tema do poema espanhol medieval Las coplas a la muerte de su padre de Jorge

\footnotetext{
${ }^{157}$ Muitos dos religiosos que acompanharam a Conquista reinterpretaram o Mictlan préhispânico, lugar aonde se dirigiam os mortos e onde se depositam seus ossos, como o inferno cristão, onde as almas eram atormentadas. In: Moctezuma, Eduardo Matos, Op. Cit.
} 
Manrique, em que a metáfora correspondente é também essa da vida no tabuleiro: "después de la vida/ tantas veces por su ley/ al tablero"158. A morte aparece como um esqueleto jogando xadrez com um homem no mural medieval do sueco Alberto Pictor feito na igreja de Taby, diocese de Estocolmo, que data entre fins do século XIII e início do século XIV. Foi nessa pintura que se baseou o sueco Ingmar Bergman para o argumento de seu filme O Sétimo Selo (1956).

$\mathrm{Na}$ imagem rulfiana, o "tabuleiro da morte" se conjuga com o imenso templo católico destacado sobre o morro que tapa o ponto de fuga dos olhos que percorrem a imagem, aprisionando-os na cena ali construída. As marcas da tradição do colonizador, portanto, sobressaem-se e se impõem violentamente nessa imagem. O gesto dos olhos que impõe a observação dessa fotografia possibilita, também, perceber que os traços europeus que compõem a paisagem estão unidos aos traços indígenas ali presentes, representados pela mulher que carrega a cesta sobre a cabeça. Observando esses elementos que dialogam entre si nos perguntamos se podemos afirmar que Rulfo teria criado nesta foto um diálogo entre a simbologia da morte europeia e a própria morte imposta à mulher indígena fotografada.

As fotografias das ruínas de templos indígenas e europeus retratados por Rulfo também nos levam a esse jogo com a morte que impõe o ato fotográfico. Essas ruínas silenciosas e impotentes diante do tempo que os deteriora, e que são agressivamente convertidas em imagens fotográficas, denunciam um passado que se transforma em sugestão ${ }^{159}$. O olhar do fotógrafo Rulfo não é agressivo, pelo contrário, é um olhar lento, que busca a comunhão

\footnotetext{
${ }^{158}$ Manrique, Jorge. Las coplas a la muerte de su padre. s/d.

${ }^{159}$ Sontag, Susan. Op. Cit., p. 95.
} 
dos objetos que mira, e que busca assentá-los nos moldes que lhes impõem, mesmo depois de reveladas as fotografias ${ }^{160}$. Porém, a máquina fotográfica e o ato de revelação terminam o seu labor com efeitos avassaladores. Em uma de suas fotos de uma ruína do interior mexicano, envolta em uma espécie de neblina, o efeito que causa ao observador é semelhante àquele atribuído a Eugène Atget por Walter Benjamin: o cenário fotografado parece o de um crime $^{161}$. E o criminoso aqui não é ninguém menos que o próprio fotógrafo que dispara sua câmera para essa paisagem.

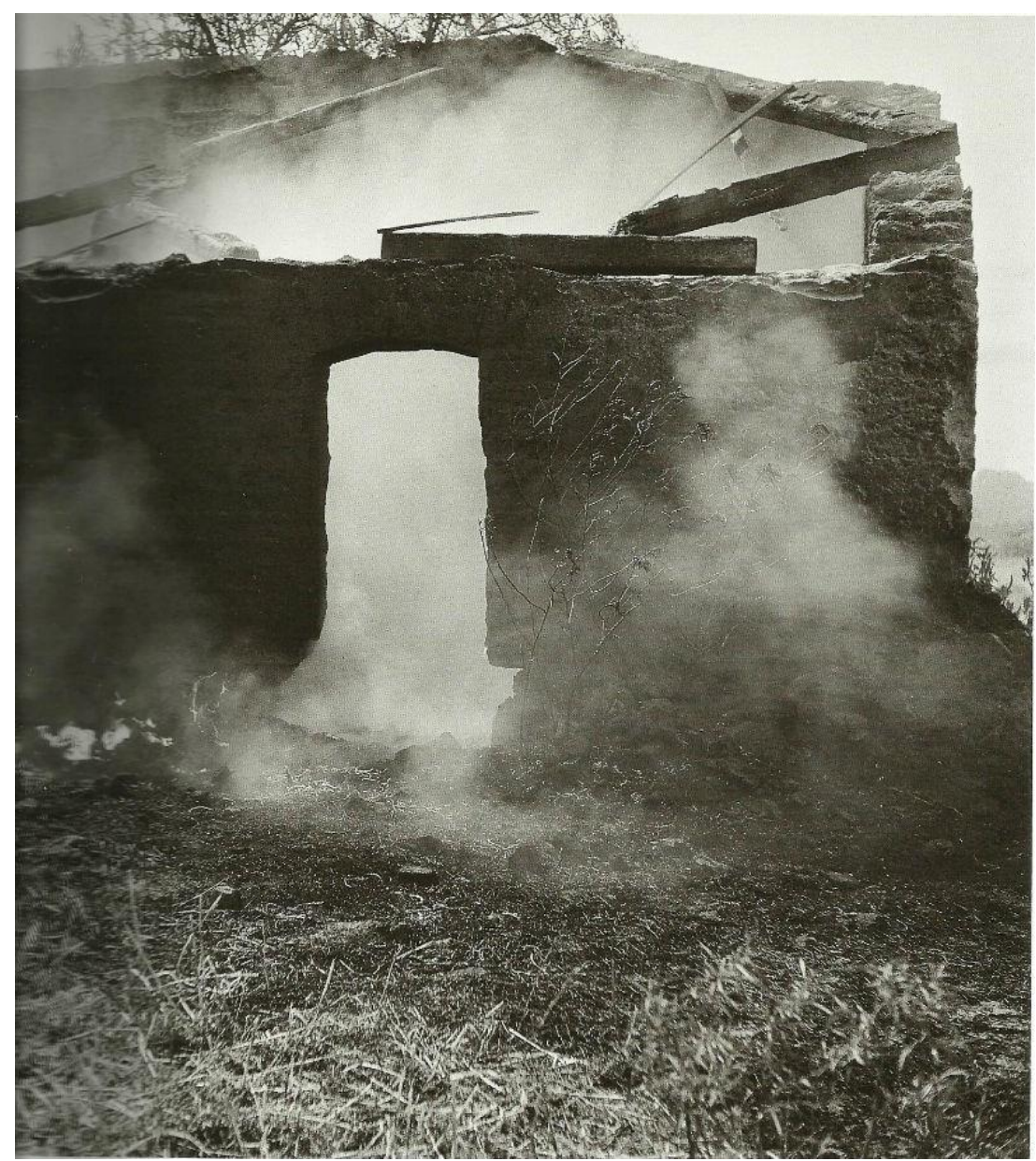

Figura 9 - Juan Rulfo, Casa em ruínas em Tlaxcala, 1955.

${ }^{160}$ Sabe-se que muitas das fotografias de Rulfo foram cortadas após serem reveladas para que permanecessem sob um formato quadrado ou permaneceram bastante pequenas devido às dimensões impostas pela Rolleiflex $6 \mathrm{~cm}$ x $6 \mathrm{~cm}$ de Rulfo.

. 161 "Sobre o conceito de história" In: Obras Escolhidas. São Paulo: Brasiliense, 1996. 
Uma foice de dupla face: a morte como motivo em Pedro Páramo e nas fotografias de Rulfo

Em Pedro Páramo, o autor implícito do romance, como o fotógrafo das fotografias rulfianas, impõe a morte a todos os seus personagens. Na viagem que Juan Preciado empreende à Comala, encontra-se apenas o silêncio e a desolação de uma cidade abandonada, cujos habitantes, todos eles, estão mortos, assim como o próprio Juan Preciado estará ao adentrar esse ambiente. A voz que narra o começo da história, "Vine a Comala...", é a voz de Juan Preciado já morto vinda de dentro de sua tumba, de onde conta sua história à Dorotea, sua interlocutora durante todo o romance, como o leitor se dará conta no decorrer da leitura. Uma vez imposto o mundo dos mortos, a grande tarefa que parece recair sobre os ombros daquele narrador é a de descrever este mundo mórbido, esboçar o que seria essa morte a partir da qual se dá toda a narrativa.

Carlos Fuentes ${ }^{162}$ identifica o encontro entre o espaço e o tempo em Pedro Páramo apenas no momento da morte. É apenas a partir da morte que podemos erigir a história dos personagens presentes no romance, e é apenas na morte que o romance se constitui como tal. A morte, nas palavras do próprio Rulfo, presentifica-se na vida mesma do autor como fruto de sua infância e da vivência da Guerra Cristera. "Solo conocí a la muerte", afirmou sobre seus primeiros anos de vida ${ }^{163}$. A morte é, portanto, a condicionante do romance Pedro Páramo.

162 Fuentes, Carlos. Valiente mundo nuevo - Épica, utopía y mito en la novela hispanoamericana. México, D.F.: FCE, 1992.

${ }^{163}$ Esse depoimento de Rulfo faz lembrar os poemas do líder asteca Nezahualcóyotl. Governante do altepetl de Texcoco, uma das várias cidades que rodeavam Tenochtitlan antes da chegada dos 
O início do romance fornece as primeiras indicações de que o personagem que começa a conduzir o leitor em sua viagem em busca do pai desconhecido encontrará em seu lugar apenas um mundo insólito. O encontro com Abundio, o arrieiro, é definitivo para essa percepção, pois é a partir da conversa que trava com Preciado que os primeiros indícios da Comala como o inferno cristão são revelados:

$$
\begin{aligned}
& \text { “- ¿Adónde va usted? - le pregunté. } \\
& \text { - Voy para abajo, señor. } \\
& \text { - ¿Conoce un lugar llamado Comala? } \\
& \text { - Para allá mismo voy."164 }
\end{aligned}
$$

A referência a um mundo inferior, abismal, entra em relação direta com o inferno cristão, que está localizado sob os "abismos tenebrosos" bíblicos (2Pedro, 2, 4) e para onde Deus envia os "ímpios para serem castigados no dia do juízo" (2Pedro, 2, 9). Como muitas leituras analíticas indicam, também se pode aludir o inferno de Dante Alighieri através dessa concepção da terra de Comala, especialmente pelas leituras feitas por Rulfo da obra maestra italiana. Mais adiante, ao afirmar que Abundio, também ele, é filho de Pedro Páramo, o narrador acrescenta, como se colocasse uma nota em um roteiro de cinema: "[u]na bandada de cuervos pasó cruzando el cielo vacío, haciendo cuar, cuar, cuar" ${ }^{\prime 65}$. Bem como o corvo de Edgar Alan Poe, esses corvos surgem como um símbolo do augúrio que encontrará Preciado na terra estagnada no tempo. Os

espanhóis à América, o tlatoani (líder) foi bastante notável pelas poesias com temáticas filosóficas que escreveu em nahua. Pertencentes aos limitados registros escritos da cultura préhispânica, seus poemas, muitas vezes, tratam da morte de forma melancólica, aludindo ao seu pai, Ixtlilxóchitl, que, como o pai de Rulfo, também fora assassinado.

${ }^{164}$ Pedro Páramo. p. 67

${ }^{165}$ Idem. 
ecos que ouve Preciado ao adentrar Comala lembram o eco do nome de Lenore, repetido pelo eu-lírico atormentado de Poe, no poema The Raven ${ }^{166}$.

Ainda mais adiante, após mostrar a Preciado toda Media Luna, a partir do planalto em que se encontram, e perguntar ao recém-descoberto irmão se teria sido ele também batizado por Pedro Páramo, Abundio segue:

“- (...) Y lo más chistoso es que él nos llevó a bautizar.

Con usted debe haber pasado lo mismo, ¿no?

- No me acuerdo.

- ¡Váyase mucho al carajo!

- ¿Qué dice usted?

- Que ya estamos llegando, señor. "167

Bakhtin, ao referir-se à literatura realista grotesca do Renascimento e Romantismo, postula que "expressões como "vai à ..." que "humilham o destinatário segundo o método grotesco", “enviam-no para o baixo corporal absoluto, para a região dos órgãos genitais e do parto, para o túmulo corporal (ou os infernos corporais)"168. Ao utilizar a expressão "váyase mucho al carajo", Abundio não se refere literalmente ao baixo corporal de Juan Preciado. Poucas vezes os corpos são protagonistas dos eventos narrados no

\footnotetext{
${ }^{166} \mathrm{Com}$ essa série de referências literárias que sugerimos a partir da leitura de Pedro Páramo, podemos esboçar uma referência paralela àquela desenhada por Echevarría sobre a narrativa latino-americana da metade do século XX. Rulfo, fugindo do discurso hegemônico, debruça-se na tradição literária para a composição de seu único romance. Disto, realizamos a aproximação de sua obra ao poema The Raven de Edgar Allan Poe e a crítica rulfina o fez ao verificar similitudes entre sua obra e A Divida comédia de Dante Alighieri, como comentamos anteriormente. Outro poema conjunto de poemas que identificamos com a mesma temática que o romance rulfiano é Spoon River Anthology (1915), do estadunidense Edgar Lee Masters, em que habitantes da cidade fictícia de Spoon River falam desde suas tumbas. Essa decisão interpretativa, por outro lado, parece ser uma decisão do leitor e de seu repertório literário, que pode, ou não, identificar a ressonância de outras obras literárias em Pedro Páramo.

${ }^{167}$ Pedro Páramo. pp. 68, 69.

${ }^{168}$ Bakhtin, Mkhail. Op. Cit., p. 25.
} 
romance rulfiano ${ }^{169}$. O único baixo que pode ser aludido na grosseria aparentemente despropositada de Abundio é aquele a que "está sobre las brasas de la tierra, en la mera boca del infierno"170 , o túmulo ao qual se dirige, ainda sem sabê-lo, Juan Preciado.

Apresentados esses primeiros indícios, os fantasmas que habitam Comala começam a aparecer. Primeiro, a mulher que vê Preciado em sua chegada que "desapareció como si no existiera"171, para em seguida reaparecer e indicar a casa de Eduviges. Logo, o encontro com Eduviges, quem diz que Abundio, com quem Preciado havia estado há pouco, estava morto, e também diz escutar a voz de Dolores Preciado já morta. Já totalmente submergido nesse universo mórbido, o silêncio e a falta de ar são mencionados, assim como as vozes que "se oían mejor. Se quedaban dentro de uno, pesadas"172.

Como mencionado no capítulo anterior, uma grande característica desse mundo dos mortos é a não linearidade do tempo. Os fragmentos que narram a entrada de Preciado ao mundo de Comala, abruptamente, passam a regressar e avançar na história da narrativa indicando que o tempo de Pedro Páramo é híbrido, não se deixa fixar, é impossível reconhecer com clareza em que tempo passam os fragmentos do romance. Assim também ocorre em algumas ações descritas pelos murmúrios dos mortos. Muito do que contam não contém transparência, não se revela ao leitor com nitidez.

Uma grande sombra de dúvidas envolve a leitura do romance de Rulfo, possivelmente por isso seu texto continua sendo visitado por estudiosos. Isso

\footnotetext{
${ }^{169} \mathrm{~A}$ passagem em que os corpos estão mais presentes e dialogam com a postulação de Bakhtin sobre o grotesco, como mencionado, é no momento daquele encontro de Juan Preciado com os irmãos incestuosos. Pedro Páramo. pp. 106-117.

${ }^{170}$ Ibidem. p. 67.

${ }^{171}$ Pedro Páramo. p. 70.

${ }^{172}$ Idem.
} 
porque esses "arquivos" orais da história de Comala, uma vez que se contrapõem a um arquivo legal, documentado, emergem diretamente das tumbas em que se encerram seus declamadores e a dificuldade da viagem do inframundo para o corpo do texto que lemos imprime a ele uma inevitável nebulosidade. Um dos casos em que o leitor não é capaz de saber com certeza o que ocorrera no evento narrado é quando o romance traz à tona a violação de Ana, sobrinha do padre Rentería, por Miguel Páramo, filho bastardo de Pedro Páramo e único que obtivera o reconhecimento e amor do pai. Ao perguntar à sobrinha se tem certeza sobre o autor da violação, a jovem responde: “[s]egura no, tío. No le vi la cara. Me agarró de noche y en lo oscuro" ${ }^{\text {173 }}$. Assim como em "Luvina", em que as sombras de velhas senhoras se confundem com uma revoada de morcegos, em Pedro Páramo as sombras atuam como um elemento importante para a indeterminação dos eventos.

A própria morte de Pedro Páramo, no final do romance, não fornece todas as informações necessárias para que o leitor visualize com claridade como se produz esse sucesso. Nas primeiras interpretações do romance, era recorrente que se atribuísse a morte do cacique ao seu filho bastardo, Abundio, quem, ébrio, teria esfaqueado o pai. Porém, em uma leitura mais atenta, percebe-se que em nenhum momento fica claro o parricídio, e a acusação a Abundio parece descabida. A mescla dos tempos, presente também nessa última passagem, é a grande responsável pela indeterminação dessa ação. O que se pode afirmar com certeza é que Pedro Páramo morre observando Comala também morrer sob sua maldição e desmorona "como si fuera um

\footnotetext{
${ }^{173}$ Ibidem. p. 88.
} 
montón de piedras" ${ }^{\text {174, }}$, transformando-se ele também naquele solo amaldiçoado.

$\mathrm{O}$ anúncio das mortes sequenciais do romance ocorre sempre em meio a uma narrativa complexa. Assim acontece quando Pedro Páramo relembra o dia da morte de seu pai, já mencionado no capítulo anterior, fragmento em que os tempos se mesclam e em que o leitor se depara com uma narrativa extremamente complexa. A notícia da morte de Bartolomé San Juan, feito pela empregada Justina à órfã Susana San Juan, eterna amante de Pedro Páramo, também ocorre sob esses moldes. A mulher de cama, já sob um estado de percepção alterado, julga ter visto o pai entrar em seu quarto para despedir-se pouco antes do aviso da morte feito pela empregada. Essa constatação faz com que, ao contrário do que se vê no fragmento da morte do pai de Pedro Páramo, em que a mãe se encontra sobre um chão "anegado em lágrimas", Susana San Juan caia em gargalhada.

É importante notar que a reação da personagem frente à morte se contrapõe com a reação da mãe de Pedro menino, possivelmente devido à loucura que a acomete. Nesses termos, percebemos, como já se deixa notar pela presença do Padre Rentería e sua importância na relação com grande parte dos personagens do romance, que Comala está regida sob os signos da religião católica. O próprio Pedro Páramo aparece como um personagem religioso. Diante da morte, portanto, o luto é bastante importante, assim como a redenção daqueles que morrem, dada pelas mãos do padre. Porém, essa redenção é submetida ao poder de Pedro Páramo, quem compra a redenção de seu filho mesmo contra a vontade do sacerdote.

\footnotetext{
${ }^{174}$ Ibidem. p. 178.
} 
No fragmento que sucede a passagem em que Susana San Juan ri da morte do seu pai, a personagem relembra um momento chave para a composição de sua personalidade e para a compreensão da sua relação com seu progenitor. Bartolomé San Juan a faz entrar, "[m]uchos años antes", em um poço em busca de ouro. A menina baixa no poço escuro, emudecida pelo medo, enquanto o pai, na superfície, pede para que recolha tudo o que encontre. E o que Susana acaba encontrando no fundo do poço e leva para a superfície são os ossos de uma caveira humana:

“- Baja más abajo, Susana, y encontrarás lo que te digo.

$Y$ ella bajó y bajó en columpio, meciéndose en la profundidad, con sus pies bamboleando en el «no encuentro dónde poner los pies».

-Más abajo, Susana. Más abajo. Dime si ves algo.

Y cuando encontró el apoyo allí permaneció, callada, porque se enmudeció de miedo.

La lámpara circulaba y la luz pasaba de largo junto a ella. Y el grito de allá arriba la estremecía:

- ¡Dame lo que está allí, Susana!

Y ella agarró la calavera entre sus manos y cuando la luz le dio de lleno la soltó.

-Es una calavera de muerto -dijo ${ }^{\text {,175. }}$.

Essa passagem é igualmente importante para a análise do símbolo da morte no romance de Rulfo. A partir dessa imersão de Susana San Juan no poço e tendo em conta a relação pré-hispânica com a morte, parece pertinente

${ }^{175}$ Ibidem. p. 147. 
relembrar o Mictlán, reino dos mortos onde se depositavam os ossos dos ancestrais indígenas e aonde, segundo a Leyenda de los soles, Quetzalcoátl baixou para buscar ossos dos quais pudesse dar origem aos homens. Os ossos encontrados por Susana San Juan, porém, não podem dar vida a nada. Ainda, o que faz a menina Susana baixar ao reino dos mortos é a ganância do pai em busca de ouro.

O riso de Susana ao saber da morte de seu pai se assoma depois de rememorar a lembrança traumática de sua infância e é repetido na festa que se instaura quando os sinos da igreja da cidade anunciam a sua própria morte. $\mathrm{O}$ povo de Comala se equivoca quanto à mensagem dos sinos e começa uma festa animada, ao invés de guardar o luto esperado e vivido por Pedro Páramo frente à morte de sua amada. Percebe-se aqui, a diferença abismal entre a festa e o luto. Não há o que se comemorar quando Pedro Páramo encontra-se em plena dor da perda. O equívoco do povo é o motivo pelo qual o cacique o condena: "[m]ecruzaré los brazos y Comala se morirá de hambre" $"$ "A morte que enfim recai sobre a cidade não é aquela cristã, que envia os pecadores ao inferno onde agonizarão e pagarão por seus pecados, mas é uma morte que impõe o confinamento do povo "comalense" ao subsolo de Comala. O inferno, em Pedro Páramo, é a própria Comala. A morte da cidade não é vista nem à maneira dos ancestrais indígenas, guardando a vida em seu germe, tampouco é vivida como mandam os dogmas católicos, sob o luto e a redenção ou a punição. Dessa forma, a morte em Comala é esvaziada de sentido.

Com o rompimento da antiga fluidez entre morte e vida identificada nas culturas pré-hispânicas, a morte em Comala só pode gerar mais morte. A

\footnotetext{
${ }^{176}$ Ibidem. p. 171.
} 
sequência em que uma morte leva a outra - não necessariamente de forma explícita - é notável: Dolores Preciado, seguida por seu filho Juan Preciado, no primeiro nível da história, no nível das memórias dos personagens mortos, o pai de Pedro Páramo, seguido pelo neto Miguel Páramo; Bartolomé San Juan, seguido por Susana San Juan, e a morte mais importante do romance, a do próprio Pedro Páramo, entre tantas outras de menor importância. Mesmo antes da maldição rogada por Pedro Páramo, já era possível notar que a cidade por si mesma carregava seus habitantes, um a um, ao reino dos mortos. Como a câmera fotográfica que impõe a morte àqueles que são delimitados em seu enquadramento, Comala assim também impõe a morte àqueles que se encontram entre suas fronteiras.

$\mathrm{O}$ ambiente em que se encontram os personagens de Comala, dominado pela cosmovisão cristã submetida ao poder de Pedro Páramo e ao poder do capital, os submete à morte. É talvez a submissão desse povo a estes dois poderes, o do cacique e do capital, a responsável pelo esvaziamento da morte. Nem a vida, nem céu ou o inferno estão acessíveis àqueles mortos, o poder impede até mesmo a fluidez da morte e impõe o eterno confinamento daqueles a que submete. Se convertido em pedras, Pedro Páramo continua a submeter o povo de Comala que jaz por debaixo das pedras que tomam a superfície do solo da cidade abandonada.

Parágrafos acima, quando comentávamos sobre a fotografia da mulher que caminha com um cesto sobre a cabeça sob a vigília da igreja de Santa Prisca, mencionamos que a igreja tampa o ponto de fuga do observador, aprisionando-o àquela cena em que o trabalho da mulher indígena está reduzido diante da ostentação do templo sobre o morro. O mesmo ocorre na 
realidade vivida em Comala, em que toda a cidade está reduzida a um poder que está ainda mais além do poder da igreja, poder este que submete indígenas e criollos e suas crenças, que os aprisiona a todos no enquadramento de uma tumba.

Como digressão, é interessante notar que Taxco, cidade onde se localiza a igreja fotografada, é uma cidade comercial, fruto da extração de prata das minas que a circundam, iniciada pelos espanhóis e que, atualmente, é grande acumuladora de joalherias que vendem objetos feitos desse metal ${ }^{177}$.

Em distintos momentos os personagens se referem aos cristeros, carranscistas e obregonistas, o que auxilia com que o crítico localize a história da narrativa entre os primeiros anos pós-revolução mexicana e tente identificar as datas exatas dos acontecimentos narrados no romance. Porém, como já havíamos mencionado, essa tarefa não é somente impossível como impertinente, pois a narrativa se desvia proposital e insistentemente da estrutura do romance realista para que esse tipo de dado seja necessário. $\mathrm{O}$ tempo da história de Pedro Páramo é antes o tempo do "nunca mais" do corvo de Edgar Alan Poe, tempo da morte, tempo da eternidade mórbida e praticamente niilista.

\footnotetext{
${ }^{177}$ Marcos Piason Natali aponta em A política da nostalgia como a reversão do mito da morte está fortemente arraigada à questão do poder material. No momento da única aparição dos indígenas no romance, estes são descritos como mercadores. Vendem folhas de alecrim à Justina Díaz por dez centavos e, antes de partirem, passam pela igreja para rezar à Virgem Maria e deixar-lhe "un manojo de tomillo de lismona". Convertidos à religião criolla, os indígenas rezam e deixam a sua esmola à santa, como se essa requeresse um pagamento, chamando atenção, mais uma vez, para a submissão da igreja ao plano material. O valor do alecrim comprado por Justina é mencionado pontualmente, como não acontece em nenhum outro momento na narrativa de Rulfo. A menção daquele valor monetário específico, portanto, como observa Natali, sublima o poder da troca de mercadoria por dinheiro que media a relação ente o indígena e o criollo. $\mathrm{O}$ único dado preciso e realista que temos em Pedro Páramo é o de que Justina Díaz pagou dez centavos por um ramo de alecrim. Natali, Marcos Piason. "Capítulo 3 - Pedro Páramo e o preço da ilusão”. In: A política da nostalgia. São Paulo: Nankin, 2006.
} 
A morte que define esse tempo, como mencionado no fragmento de "Después de la muerte", não é nem o "nada" nem o "algo". Não é o nada porque é a partir da morte que se dá o romance, é na morte que os personagens narram suas lembranças e, segundo o já citado Carlos Fuentes, é a partir dela que se compreende a narrativa. Não é "algo" porque a morte em Pedro Páramoé também estagnação, é suspensão do tempo, espaço sem ação e lugar onde os signos se problematizam ${ }^{178}$. A única ação descrita pelos mortos de Comala que se refere ao eterno presente da morte que "vivem" é em relação à humidade do solo que os molesta e os faz queixar-se ainda mais.

A morte em Pedro Páramo, portanto, foge de qualquer definição, foge das duas grandes culturas sobre as quais se estrutura toda a sociedade mexicana, a indígena e a criolla, e se posiciona em um espaço de quase impossível definição, num discurso mágico, mas não mítico, realista, mas não verossímil $^{179}$.

A fuga do texto de Juan Rulfo do realismo e da descrição detalhada, a preferência pelos espaços vazios que o leitor deve preencher, a utilização de um alto teor poético, remete à escolha do autor de não se alinhar aos discursos hegemônicos, como também o fizeram grande parte dos escritores da literatura latino-americana, principalmente a partir da segunda metade do século XX. Os discursos hegemônicos são, precisamente, aqueles que explicam, que analisam

\footnotetext{
${ }^{178}$ Este trecho faz alusão à passagem do romance, já mencionada no capítulo anterior, em que Juan Preciado se refere a sua interlocutora, Dorotea, por Doroteo, marcando a perda da referência representada pela desinência de gênero $-a$ que distingue o nome da mulher.

${ }^{179} \mathrm{O}$ realismo presente na obra é aquele que advém da menção de dados monetários, como os dez centavos pagos por Justina, e históricos, como a citação dos cristeros, carrancistas e obregonistas, porém estes dados não estão submetidos à lógica da narrativa realista definida por críticos como Lukács. São dados, mais bem, que ajudam a compor, com o complexo tempo e espaço de Pedro Páramo, a indeterminação da narrativa de Rulfo.
} 
e que dissecam o material a que se referem, como são o discurso da lei, da ciência e do Estado ${ }^{180}$.

Na fotografia, como mencionado, o discurso técnico é colocado de lado para fazer-se referência ao processo poético capaz de gerar imagens aniquiladoras. A falta de legenda na maioria das fotos de Rulfo contribui ainda mais com que as imagens não sejam simplesmente retratos da realidade, mas que apresentem uma visão poética do entorno que Rulfo fotografava. Esses dois discursos relacionam-se diretamente na obra do escritor-fotógrafo, discurso poético narrativo e discurso poético do processo fotográfico, e apontam para o olhar sobre o mundo que possuía o autor.

Com a dizimação de todo um povo através da escrita desse autor impiedoso, temos a única certeza de que o que está ali narrado nunca mais ocorrerá. Não apenas aqueles que sofreram a submissão ao poder do cacique Pedro Páramo padecem em Comala, mas o próprio cacique tampouco foge à ceifadora que aniquila todo o seu povoado. É interessante notar que, além das mortes mencionadas em Pedro Páramo há outra morte subentendida na leitura do romance. Echevarría afirma que:

“Nuestra propia anagnórisis como lectores se reversa hasta la última página, cuando la novela concluye y cerramos el libro para dejar de existir como lectores, para ser, por decirlo así, asesinados en ese papel. "181

\footnotetext{
${ }^{180}$ Estes discursos são aqueles chamados de discursos "sérios" nas palavras do linguista John Langshaw Austin, a que se oporiam os discursos "não sérios", como o da literatura. Em:Austin, John Langshaw. How to do things with words. Cambrigde: Harvard University Press, 1975. ${ }^{181}$ Echevarría, Roberto González. Mito y Archivo. Uma teoria de la narrativa latino-americana. México, D.F.: FCE, 2011, p. 63
} 
Tendo em vista estas considerações, portanto, podemos afirmar que a sequência de mortes em Pedro Páramo conduz também o leitor a essa última morte inevitável. Como na fotografia em que a morte extrapola a questão temática, nessa postulação, há uma morte intrínseca também no ato da leitura, que independe da temática abordada pelo romance.

Com o seu trabalho fotográfico, temos em frente os objetos mortos pela câmera, cenas que não se repetirão, personagens espectrais, ruínas que desabaram sob o enfoque das lentes, composições que não existem a olho nu e que não podem ser reproduzidas por uma nova tomada fotográfica ${ }^{182}$. E tanto a morte presente na escrita quanto aquela presente na fotografia de Rulfo estão rodeadas por elementos que encobrem os eventos narrados e fotografados de mistério. A morte, ainda que presente em ambas as obras do autor não é descrita, tampouco revelada.

Havíamos afirmado no início que a concepção da morte no México é vista a partir de um discurso parte histórico, parte mítico, de difícil compreensão. A fotografia, por sua vez, é analisada em nosso trabalho como um discurso poético quando em seu processo de revelação. Este discurso aqui considerado para a análise da fotografia foge ao discurso explicativo. Mencionamos, ainda, que a narrativa de Rulfo também foge àquele tipo de discurso, pois é construída a partir de imagens poéticas que englobam a temática da morte. Com essas três afirmações, percebemos, portanto, que Rulfo, em seu trabalho artístico, insere seus temas em uma composição que dialoga diretamente com a sua complexidade. O conceito de morte, assim

\footnotetext{
${ }^{182}$ Em viagem à Taxco de Alarcón, no estado de Guerrero, busquei o lugar de onde havia tomado a foto da mulher abaixo da igreja de Santa Prisca. Percorri grande parte da cidade, subi em diversos edifícios, mas o lugar em que Rulfo tomara a foto não se revelou. Porém, ainda que a encontrasse está a certeza de que o que vemos na fotografia em análise de maneira alguma poderia ser retomado a partir da visão do local.
} 
como o de tempo e história, está carregado de problemáticas que podem ser identificadas nas fotografias e na narrativa de Rulfo. A partir da morte, ainda, é possível ver despontar questões caras aos dois outros conceitos destacados na nas obras do mexicano. A morte é a responsável pela confusão temporal por que passa a narrativa e que acaba desnorteando as ações dos personagens e, também, remete às concepções presentes na cosmogonia pré-hispânica e à história violenta do México moderno.

\title{
Capítulo 3 - $O$ tempo e a morte como suporte para a história
}

\author{
nas obras de Juan Rulfo.
}

\section{$A$ “verdadeira” inclinação}

Em ocasião da visita do arquiteto Víctor Jiménez à vasta biblioteca de Juan Rulfo, este respondeu ao elogio do amigo, que o parabenizava por ter uma boa biblioteca: "no, una buena biblioteca es una de historia; yo solo tengo literatura"183. Ainda, Rulfo mencionou em entrevista ao jornal espanhol Diario, em 1982, que a sua "verdadeira vocación es la historia. Lo de la literatura vino como tenía que venir, como una cosa aparte..."184.

As anotações de rascunhos de Rulfo também expõem a inclinação do escritor aos estudos da história de seu país e continente. Vários são os comentários que escreve referentes a ruínas de templos pré-hispânicos e

\footnotetext{
${ }^{183}$ Jíménez, Víctor, apud Quijas, Fabiola Palapa. "La verdadera vocación de Rulfo fue la historia, dice el hijo del escritor". La Jornada. Cidade do México, 23 de julho de 2009. Cultura, p. 9.

${ }^{184}$ Jiménez, Víctor. "Una estrella para la muerte y la vida". In: Jeppesen, Anne Marie Ejdesgaard (coord.) Tras los murmullos. Copenhaguem: MuseumTusculanunPress. Universidade de Copenhaguem, 2010.
} 
espanhóis encontrados no interior do México. O interesse de Rulfo em relação àquelas construções o levou a realizar diversas excursões ao interior do país, acompanhado de sua câmera fotográfica com que tirou centenas de fotos. Desta forma, vemos Rulfo também como um antropólogo, cargo que segundo ele próprio, o havia afastado da escrita ${ }^{185}$.

Contudo, um raro momento em que Rulfo surge como alguém desvinculado de seu trabalho artístico com a escrita e a fotografia e dialoga diretamente com a história é o prefácio que faz a Hablan los aztecas: historia de las cosas de Nueva España do frei Bernadino de Sahagún. Escrito entre os anos de 1540 e 1585, o Códice Florentino, como foi primeiramente chamado, é um trabalho minucioso de Sahagún em busca de adentrar a cosmogonia nahua. León-Portilla chamou o frei de "antropólogo pioneiro", devido ao seu trabalho junto aos membros das antigas elites indígenas nahuas.

Sabendo da vivência de Juan Rulfo com o mundo da antropologia nos anos em que trabalhou no Instituto Nacional Indigenista do México, a aparição de seu prefácio a uma das edições de Hablan los aztecas... parece ainda mais coerente. León-Portilla, ainda sobre o trabalho do frei, afirma que Hablan los aztecas... se trata de uma: "obra, en suma, digna (...) del estudio de cuantos quieran conocer a fondo el legado espiritual de los antiguos pueblos nahuas del altiplano central de México" ${ }^{186}$.Veremos adiante que a partir da narrativa e da fotografía rulfiana podemos notar nuances desse legado espiritual mencionado pelo historiador.

\footnotetext{
${ }^{185}$ Árismendi, Juan Carlos Orrego. "Lo indígena en la obra de Juan Rulfo. Vicisitudes de una mente antropológica". In: Revista Co-herencia. Julho a dezembro de 2008, vol. 5, n. 9. ISSN 1794-5887. Universidad EAFIT, Medellín, Colômbia, p. 96.

${ }^{186}$ León-Portilla, Miguel. "Bernadino de Sahagún $(1500$ - 1590). Un juicio lapidario sobre su historia". In: Caravelle. Toulouse: Presses Universitaires du Midi. Université de Toulouse le Mirail, v. 55, n. 1, 1990.ISSN: 1147-6753
} 
Não é apenas a história pré-colombiana que percebemos resvalar nas obras de Rulfo. A Conquista, a história moderna e até mesmo o imperialismo norte-americano de fins do século XX são identificados em leituras e observações atentas de seus escritos, de suas fotografias e de suas participações no audiovisual mexicano ${ }^{187}$. O próprio autor afirmou que Pedro Páramo traz afigura do encomendero colonial. Esta figura está amplamente atuante nos primeiros anos da Conquista e sua presença é primordial para a análise da questão agrária nas ex-colônias espanholas até os dias de hoje. Segundo a visão revolucionária mexicana, as encomiendas eran terras que "comprendían grandes extensiones de dichas tierras con sus pobladores. Poco tardaron esas encomiendas en convertirse, por la extinción o expulsión de los indios, en grandes haciendas de cultivo y ganadería, tituladas en la forma de propiedad privada del tipo romano. Después cuando ya las encomiendas habían desaparecido, se fueron dando por los reyes y virreyes nuevas grandes extensiones en haciendas tituladas del mismo modo, sin más limitaciones que las resistencias de los indios ${ }^{188}$. Afirma-se ainda que essas possessões de terra se ampliaram e foram legitimadas. O poder que Pedro Páramo exerce sobre a Media Luna, a despeito de qualquer tipo de documentação que pudesse lhe garantir reais direitos sobre as terras em que atua, parece ter bastante semelhança com este tipo de relação com a terra que passaram a ter os encomenderos desde a Conquista. É interessante notar, contudo, que a

\footnotetext{
${ }^{187}$ Quanto às participações de Rulfo no cinema, as mencionaremos apenas brevemente. Entre 1956 e 1958, Rulfo escreve a novela-roteiro El Gallo de Oro, levada ao cinema por Roberto Galvadón em 1965. Em 1960, participa da concepção do meio-metragem El despojo, de Antonio Reynoso e Rafael Cordiki e, cinco anos mais tarde, é autor do texto do filme La fórmula secreta, de Rubén Gámez. É neste último que percebemos a obra de Rulfo voltar-se para temas da cidade grande e do imperialismo norte-americano.

${ }^{188}$ Enríquez, Andres Molina. Apud Zavala, Silvio. "Orígenes coloniales del peonaje en México". In El trimestre económico. Cidade do México: Fondo de Cultura Nacional, v. 10, n. 40(4), janeiro a março de 1944, pp. 711-748. ISSN 00413011.
} 
descrição das encomiendas feita pelo revolucionário Enríquez Molina não se distancia da descrição das terras fictícias da Media Luna que datam, apesar das várias ressalvas quanto à contextualização da obra em questão, nos anos posteriores à Revolução. Aquele tipo de dominação, portanto, persiste desde a chegada dos espanhóis até o México pós-revolucionário, de acordo com o romance. A permanência da personagem do encomendero nos traz uma pista de como a história está representada na narrativa rulfiana.

Como mencionado ao tratarmos sobre o tempo em Pedro Páramo e nas fotografias de Rulfo, a linha cronológica a que se submete a história não deve ser reconstituída para nos auxiliar na contextualização das obras ${ }^{189}$. A história em Juan Rulfo se desprende da linha sucessiva, da continuidade, da mera descrição e explicação. Portanto, se pensarmos propriamente na historiografia que poderia embasar, de certa forma, o que vimos afirmando emanar de suas obras artísticas, vislumbraríamos nas estantes da "boa biblioteca" de história de Rulfo títulos de autores como Michel Foucault, Hayden White e Dominick Lacapra. Pensamos nesse autores porque se dedicaram, cada qual à sua maneira, a se opor à historiografia clássica apontando para a descontinuidade e a interpretação no labor do historiador.

Não partiremos, portanto, da suposição de que Juan Rulfo foi um historiador, mas tentaremos analisar suas obras, escrita e visual, a partir de certas diretrizes historiográficas que dizem respeito a características daquelas suas obras. A questão da descontinuidade, por exemplo, abordada por Foucault em $A$ arqueologia do saber, parece bastante pertinente se voltamos a analisar, a partir do viés do tempo, o romance Pedro Páramo e as fotografias rulfianas.

${ }^{189}$ Cf. "Capítulo 1 - Os tempos da fotografia e da literatura”. 
Segundo Foucault, para a história clássica, "a descontinuidade era o estigma da dispersão temporal que o historiador se encarregava de suprimir da história" ${ }^{190}$.Vale a pena citar de forma completa como o filósofo francêsaproxima a história que descreve como a sua contemporânea ao labor antropológico, distinguindo-a de uma história apegada à verdade dos documentos, como aquela defendida pelos primeiros historiadores da escola dos Annales:

"Digamos, para resumir, que a história, em sua forma tradicional, se dispunha a 'memorizar' os monumentos do passado, transformá-los em documentos e fazer falarem estes rastros que, por si mesmos, raramente são verbais, ou que dizem em silêncio coisa diversa do que dizem; em nossos dias, a história é o que transforma os documentos em monumentos e que desdobra, onde se decifravam rastros deixados pelos homens, onde se tentava reconhecer em profundidade o que tinham sido, uma massa de elementos que devem ser isolados, agrupados, tornados pertinentes, inter-relacionados, organizados em conjunto. Havia um tempo em que a arqueologia, como disciplina dos monumentos mudos, dos rastros inertes, dos objetos sem contexto e das coisas deixadas pelo passado, se voltava para a história e só tomava sentido pelo restabelecimento de um discurso histórico; história em nossos dias se volta para a arqueologia - para a descrição intrínseca do monumento" ${ }^{\text {191 }}$ (grifos do autor).

Dessa exposição foucaultiana podemos nos ater a alguns vocábulos já utilizados por nós para descrever as fotografias de Juan Rulfo. O monumento e

\footnotetext{
${ }^{190}$ Foucault, Michel. A arqueologia do saber. Rio de Janeiro: Forense Universitária, 2008, p. 9.

${ }^{191}$ Ibidem, p. 8.
} 
o silêncio, agora requeridos pelo discurso histórico, estão presentes sobremaneira no discurso que empregamos para descrever as fotografias mencionadas. A "atividade de catar de antiguidades", apontada por Sontag como própria do fotógrafo quando aponta sua câmera para as coisas do mundo, é ainda mais acentuada quando o que o fotógrafo tem enfocadas são as ruínas de um passado que deixaram de se presentificar enquanto matéria imparcial, direta, autodescritiva. O que se tem, no final, são ruínas mudas que devem ser perscrutadas atentamente para que a partir delas se possa ter alguma indicação desse passado perdido para sempre, e para que se compreenda o presente ao qual elas agora pertencem. ${ }^{192}$

Seguindo nossa descrição, os "monumentos mudos, dos rastros inertes, dos objetos sem contexto e das coisas deixadas pelo passado" podem ser as ruínas nas fotografias que mencionamos. Despegadas da linha cronológica, as imagens retratadas por Rulfo nos impõem o silêncio e o olhar para um passadoque não conta uma história linear, mas que surge combinado com o presente daquele que o observa e com o presente do momento de fabricação da imagem. Tais quais os monumentos referidos por Foucault, as fotografias rulfianas, por não serem elas mesmas a imagem do passado, descaracterizam-se enquanto documento e se assumem enquanto "monumentos mudos".

\footnotetext{
${ }^{192}$ Nesse mesmo caminho, o da imagem como abertura para o discurso histórico, ao falar sobre o papel dos filmes no discurso histórico, Robert Rosenstone aproxima o labor do cineasta, que se utiliza de imagens, ao de um historiador, ao passo que ambos "confrontam vestígios do passado (rumores, documentos, edifícios, lugares, lendas, histórias orais e escritas) e os usam para contar enredos que fazem sentido para nós no presente". A busca do sentido, contudo, não obriga a transformação desses vestígios em documentos escritos, as próprias imagens, em sua sintaxe visual, criam os sentidos citados. Rosenstone, Robert Apud Costa, Grace Campos. Dias, Rodrigo Francisco. "O cinema como narrativa histórica: Robert A. Rosenstone e a linguagem histórica fílmica". In: Revista de História e Estudos Culturais. Maio, junho, julho e agosto de 2010,vol. 7, ano VII, n. 2. ISSN 1807-6971.
} 
Outro autor que nos é importante para essa busca da história nas obras rulfianas, Hayden White, teoriza sobre um modelo em que a crítica literária serve de alicerce para a análise do discurso histórico. Segundo White, "[d]iz-se às vezes que o objetivo do historiador é explicar o passado através do 'achado', da 'identificação' ou da 'descoberta' das 'estórias' que jazem enterradas nas crônicas; e que a diferença entre 'história' e 'ficção' reside no fato de que o historiador 'acha' suas estórias, ao passo que o ficcionista 'inventa' as suas. Essa concepção da tarefa do historiador, porém, obscurece o grau de 'invenção' que também desempenha um papel nas operações do historiador" ${ }^{\prime 193}$.

A abordagem de White vai direto ao texto, analisa o trabalho que o historiador emprega a sua escrita para reconstituir os fatos, não como descrição do "achado", mas com um trabalho semelhante àquele do escritor de ficção e, por isso, passível a uma crítica literária.

O que buscamos, por nosso lado, ao analisarmos os dados históricos em Pedro Páramo é o caminho contrário: não aquele do texto historiográfico que caminha de encontro à crítica literária, mas o da narrativa ficcional que vai de encontro à história. Esse caminho, no romance em questão, é bastante tortuoso uma vez que a história surge desprovida do tempo cronológico. Nesse sentido, Marc Bloch define a disciplina da história como a ciência do "homem no tempo". Se em Pedro Páramo, o tempo está problematizado, como é possível aludir à história a partir do romance? Iremos caminhar em busca de uma resposta a essa pergunta.

\footnotetext{
${ }^{193}$ White, Hayden. Meta-História: a imaginação histórica do século XIX. 2. ed. Tradução de
} José Laurênio de Melo. São Paulo: EDUSP, 1995, p. 22. (Coleção Ponta, 4) 
A partir de White, Dominick Lacapra verifica uma aproximação entre a história, a política e o romance, ao postular, principalmente, sobre a forma do romance moderno que, diferente do discurso histórico que ainda estaria atrelado ao realismo do século XIX, pôde refutar os discursos unificadores e certos paradigmas impostos à sociedade pós-moderna através da linguagem. Para isso, Lacapra, se refere ao tempo em To the light house (1927), de Virginia Woolf, que se utiliza de justaposições entre presente e passado para criar imagens literárias em que ambos os tempos podem ser compreendidos ${ }^{194}$. Da mesma maneira como havíamos descrito o tempo nas obras de Juan Rulfo, Lacapra percebe ser construído o romance de Woolf, à luz de Joseph Frank, e aponta essa característica como aquela utilizada pelas obras pós-modernas para marcar sua ruptura com os discursos tradicionais. Em Pedro Páramo vemos essa construção da história aos moldes do que Lacapra vê em Woolf.

Portanto, a partir desses autores e, tendo em vista os deslocamentos possíveis entre os demais teóricos da literatura e da fotografia aqui utilizados, buscaremos, neste capítulo final, relacionar as obras de Rulfo a uma visão da história.

Em seu trabalho visual, Rulfo fotografa antiguidades que, dotadas de um discurso histórico, podem remeter ao passado do presente do clique do fotógrafo. Mas elas mesmas não são aquele passado, já problematizado por sua simultaneidade com o presente do fotógrafo. A partir de suas fotografias, podemos notar, também, a contemporaneidade em que o escritor-fotógrafo viveu, as características daquele presente que para o olhar do espectador do século XXI também é passado. Percebe-se, de acordo com este segundo olhar,

\footnotetext{
${ }^{194}$ Lacapra, Dominick. "History, time, andthe novel". In: History, politics, and the novel. Ithaca:
} Cornell University Press, 1987. 
as nuances das primeiras décadas do século passado, a consolidação da modernidade em um México indígena. Dentro deste tema, Rulfo escreveu sobre os índios no México da década de cinquenta: "[q]uienes andan por ahí, unos cuantos desaforados buscando problemas a este pobre país, han recorrido muchos miles de quilômetros para descobrir que en México todavia hay índios. Sí, millones de índios tristes y feos, dicen" ${ }^{195}$. Essa irônica descoberta, que pode ter sido a sua própria descoberta ao viajar pelo interior do país, está representada em nas fotografias. Porém, não são as características que se sobressaem nessas imagens contemplativas e majestosas. Ainda que em sua narrativa o indígena esteja quase completamente ausente, nas imagens que fez ele é quase elemento primordial, tanto em sua presença humana como em relação à herança cultural indígena pré-hispânica.

A ironia da história contemporânea que Rulfo destaca no trecho citado está representada na fotografia que faz de um menino com traços indígenas, com roupas e mãos sujas bebendo uma Pepsi. Como em uma fotografia publicitária, o garoto em primeiro plano e centralizado, entorna a garrafa com bastante vigor. Seus olhos fechados, a posição da mão livre no ar, o corpo levemente inclinado para melhor sorver o líquido da garrafa demonstram o deleite que o refrigerante gera. Nessa fotografia, Rulfo inscreve a sua contemporaneidade em que assistiu ao crescente imperialismo norte-americano invadir toda a América Latina ${ }^{196}$.

\footnotetext{
${ }^{195}$ Rulfo, Juan. Los cuadernos de Juan Rulfo. Op. Cit., p. 163.

196 O mesmo se dá com ainda mais ênfase no filme La fórmula secreta, dirigido por Rubén Gámez em 1965, portanto, na mesma década em que a fotografia de Rulfo foi tirada. O filme surrealista começa com uma cena em que Coca-Cola é injetada de forma intravenosa em uma pessoa. Ao longo do filme, percebe-se uma clara crítica ao imperialismo norte-americano. Um poema de Rulfo feito para o filme é recitado quando imagens de campesinos pobres são contrapostas às imagens de uma Cidade do México caótica, em que o cadáver de um trabalhador é confundido com um saco de cimento.
} 


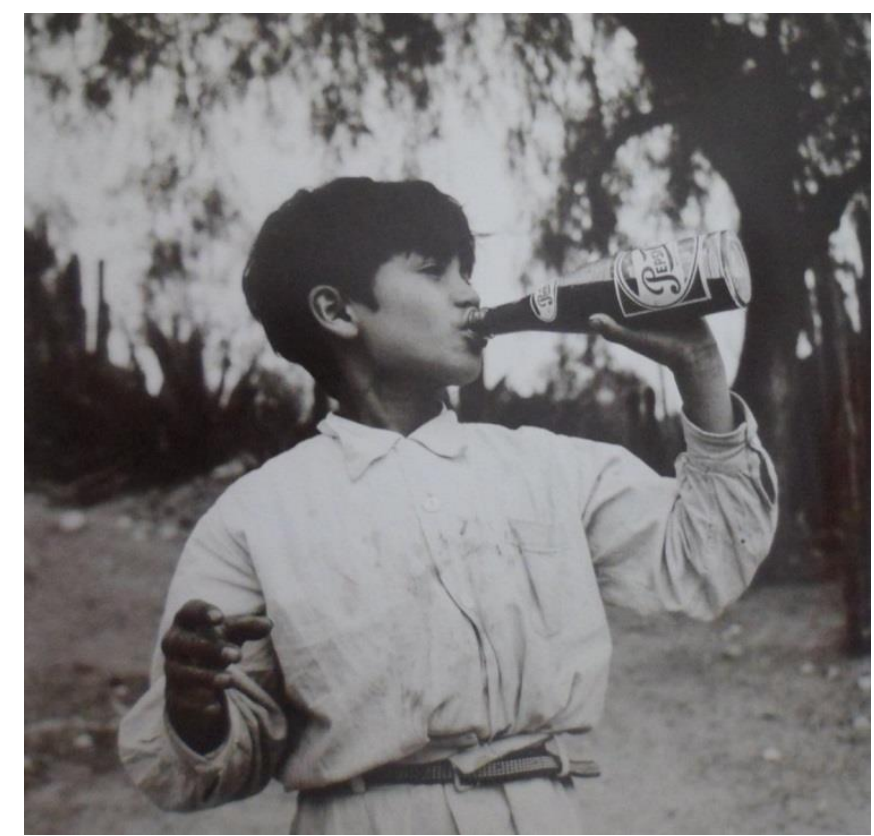

Figura 10 - Juan Rulfo, Menino de vilarejo com refresco, 1960.

Portanto, pode-se analisar a historicidade das imagens fotográficas de Rulfo através de dois caminhos: o primeiro, aquele dos objetos fotografados que rementem a um passado anterior àquele do momento da tomada fotográfica; o segundo, aquele do presente do Rulfo fotógrafo e passado do espectador contemporâneo. Neste trabalho, nos voltaremos especificamente sobre o primeiro. A questão do presente do fotógrafo nos foi bastante cara ao primeiro capítulo em que analisávamos a hibridez do tempo fotográfico. Contudo, ao tratar de história, tentamos olhar os objetos fotográficos a partir dos olhos de Rulfo, considerando as escolhas de objetos e enquadramento importantes para a impressão de sua visão da história de seu país.

O olhar que recai sobre as ruínas da história do México é um olhar contemplativo e enaltecedor. O fotógrafo viaja pelo país e o descobre, tanto quanto aqueles "desaforados" que ironiza. Contudo, o descobre parcialmente, uma vez que a busca pela história através das ruínas é bastante problemática. 
Frente a essa história que se esquiva, em suas fotografias, Rulfo não somente documenta o que presencia, mas lhes dá um significado que transcende o mero registro, cria uma fotografia monumental ${ }^{197}$.

Portanto, ao revelar as imagens dos templos coloniais, das ruínas préhispânicas e de trens obsoletos em um país em que a modernidade chega acelerada, mais do que revelar a história por trás dessas imagens, Rulfo ergue seus próprios monumentos históricos numa mise en abyme.

O único romance de Rulfo, de forma semelhante ao que ocorre na fotografia, narra sobre a tentativa de coletar dados do passado a partir da busca de Juan Preciado. São os murmúrios de toda a cidade que revelam a sua história e a de seu povo. Contudo, esse passado também é recriado e a condição de mortos imposta àqueles capazes de narrá-lo - ou, melhor dizendo, murmurálo - dificulta a elaboração de um discurso pleno que revele a história que tentam resgatar. Ainda, os eventos históricos identificados por esses murmúrios são furtados da linha cronológica da história, submetidos, eles também, à temporalidade do mundo dos mortos.

Em ambas obras rulfianas, tanto fotográfica como escrita, podemos estabelecer uma analogia com as teorias historiográficas aqui mencionadas e identificar uma visão da história conjugada à estética artística. Essa analogia é ainda mais embasada quando nos lembramos do que o próprio Rulfo chamou de sua "verdadeira inclinação". O que percebemos nessa análise é que a inter-

\footnotetext{
197 Ao tratar da diferença entre documento e monumento, Jacques Le Goff, assim como Foucault, contrapõe a antiga visão dos historiadores positivistas, que defendiam a nula interferência do historiador frente aos documentos que deveriam embasar a escrita histórica, aos novos métodos da história contemporânea que provocou a ampliação do que era considerado documento e, consequentemente, tornou muito mais complexo e ativo o papel do historiador frente aos materiais (que podem ser imateriais) que lhe servirão de base para seu trabalho. Jacques Le Goff ,"Documento/Monumento”. In: História e Memória. Campinas: Editora Unicamp, 1994.
} 
relação de suas obras através da temática da história revela a visão única que permeia o trabalho artístico do mexicano em suas diferentes linguagens.

\section{As fotografias da história}

Henri Cartier-Bresson presenteou Juan Rulfo com uma de suas fotografias após este ter escrito um texto ${ }^{198}$ para o catálogo da exposição Carnet de notes sur le Mexique, realizada em 1984 no Centro Cultural do México, em Paris. A exposição continha fotografias do francês tiradas durante sua estadia no México ${ }^{199}$. Cartier-Bresson percorreu bairros populares da capital mexicana, tais como La Merced, conhecido pela sua intensa atividade comercial com a presença de vários tianguis, e pelo movimentado Mercado de la Merced.

A fotografia presenteada a Juan Rulfo, contudo, não retrata a atividade comercial de um bairro popular. Representa, na verdade, um paredão de fuzilamento, frente ao qual um homem se posiciona de costas para o fotógrafo. Descrita por Rulfo como "muda testemunha do que havia sido a violência e a repressão [no México]"200, a foto oferece um rico cruzamento entre a estética de Cartier-Bresson e a de Rulfo. Nesta foto, o momento decisivo está presente: o homem de costas para a câmera fotográfica e de frente para o paredão tem o corpo torcido por um movimento inacabado, provavelmente flagrado enquanto caminhava em direção ao paredão. A perna direita está levemente dobrada, o braço esquerdo contraído junto ao corpo. A imagem deste homem,

\footnotetext{
${ }^{198}$ Mencionamos brevemente o texto da exposição aqui citada no primeiro capítulo de nossa dissertação. Conf. "Capítulo 1 - Os tempos da fotografia e da literatura", p. 17

${ }^{199}$ Rulfo, Juan. "O México dos anos 1930 visto por Henri Cartier Bresson". In: 100 fotografias: Juan Rulfo. São Paulo: Cosac Naif, 2010.

${ }^{200}$ Ibidem, p. 22.
} 
surpreendido em meio a um caminhar incompleto, lembra-nos o personagem Luis da Silva do romance Angústia de Graciliano Ramos (1936), quando aquele vê a si mesmo em sua memória como um homem fotografado: "[t]enho a impressão de que uma objetiva me pegou, num instantâneo. Ficarei assim, com a perna erguida, a pasta debaixo do braço, o chapéu embicado”. A pausa na narrativa, no momento em que o personagem relembra a caminhada rumo ao trabalho, se dá como num clique de um fotógrafo sobre o objeto observado. O movimento é interrompido para que o narrador recomece a narrativa desde outro ponto em sua memória. Assim, o Luis da Silva da memória do Luis da Silva narrador é deixado congelado, numa posição cômica, em silêncio, e sem que sua história se conclua.

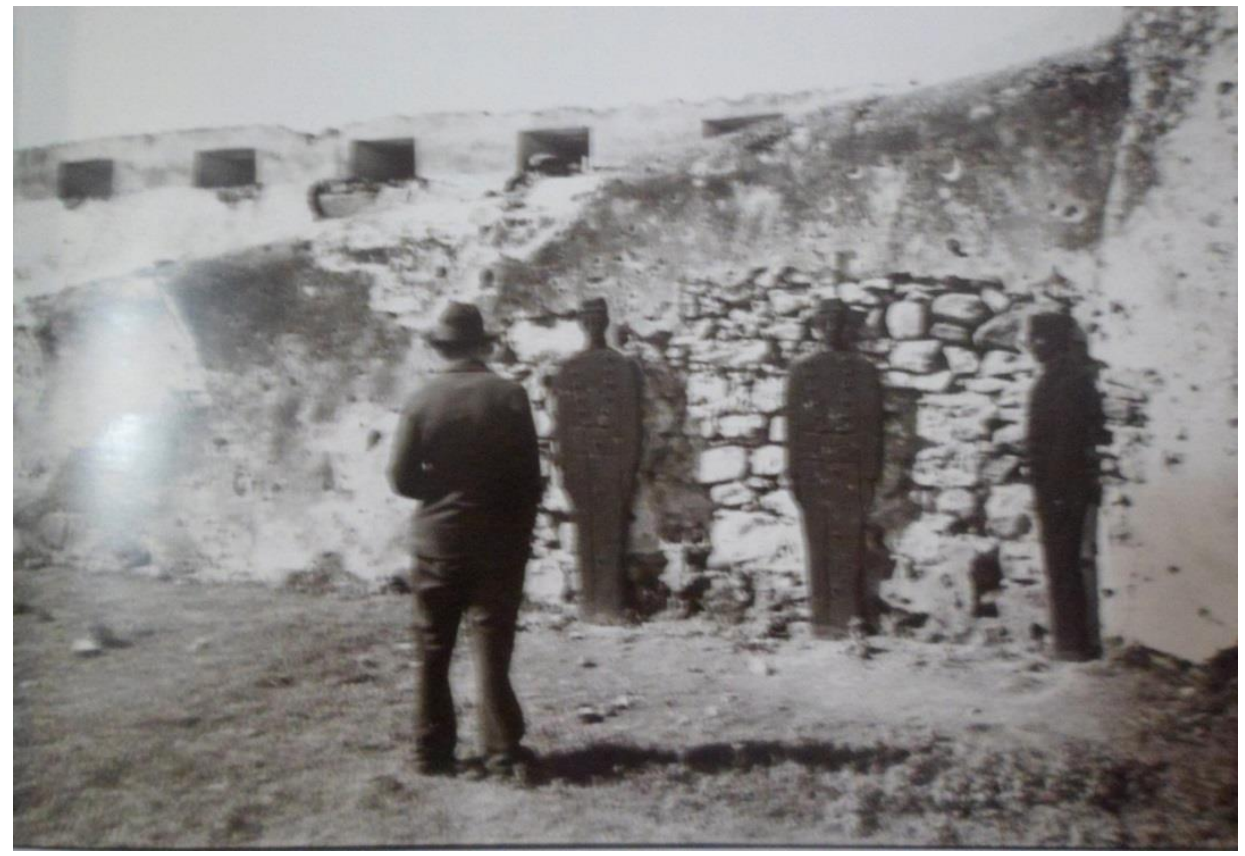

Figura11 -Henri Cartier-Bresson, Para Juan Rulfo, s/d.

Paralelamente ao instante que flagra o homem de membros retorcidos, na fotografia de Cartier-Bresson, destaca-se o tempo histórico: as silhuetas junto ao muro que, num primeiro momento parecem sombras, denunciam ao 
homem paralisado e ao espectador da fotografia o passado violento a que se refere Rulfo no texto sobre a dita exposição. De certa forma, a reverberação do corpo do homem como sombra nas silhuetas faz com que a morte, decorrente da história ali representada, seja expressa tanto no sentido que damos ao paredão de fuzilamento, como por aquele já aludido ao ato do fotógrafo que impõe os objetos à morte fotográfica.

O texto de Rulfo referente às fotografias de Cartier-Bresson deixa clara a historicidade que o mexicano emprega às imagens. Ainda que o francês se volte para o presente, Rulfo enxerga o passado acenando silenciosamente através do instantâneo fotográfico. A "muda testemunha" da história se assemelha ao "monumento mudo" a que se refere Foucault. Rulfo percebe que as imagens como tais não representam tacitamente a história, o texto que apresenta para descrever a exposição é o discurso histórico que emprega às imagens, construído a partir da mudez daquelas. Ainda que os olhos de CartierBresson se voltassem sobremaneira ao instante presente, o tempo histórico abre uma fenda no tempo imediato do olhar do francês fazendo, através do discurso de Rulfo, discorrerem anos e anos da história do México.

A "testemunha" que surge no discurso de Rulfo também remete aos postulados de Marc Bloch quando, em sua Apologia da história, revela a importância das testemunhas e dos documentos no momento em que estes parecem pouco fiáveis aos olhos daquela historiografia tradicional. Bloch afirma que "a diversidade dos testemunhos históricos é quase infinita" e que "[t]udo que o homem diz ou escreve, tudo que fabrica, que toca pode e deve informar sobre ele"201. Percebemos, portanto, que há espaço para a dúvida no

\footnotetext{
${ }^{201}$ Bloch, Marc. Apologia da história ou ofício do historiador. Rio de Janeiro: Jorge Zahar, 2002 , p.80.
} 
discurso histórico, que esse discurso deve se construir sobre os vazios que as testemunhas diretas e indiretas deixam. O que Rulfo faz ao mencionar a história das testemunhas mudas que são as fotografias de Cartier-Bresson é considerar essa faceta da história, tê-la enquanto vazios que olhos treinados como os de Rulfo podem completar.

É importante, também, retomar algo sobre o tempo na fotografia ao tratar de sua historicidade, pois se há história por trás das imagens, elas estão dotadas de tempo ${ }^{202}$. As impressões de Rulfo acerca da história de seu país, a partir do momento decisivo construído por Cartier-Bresson, demonstram que o escritor-fotógrafo não ignora a presença do tempo na imagem. De acordo com a descrição que faz das fotos de Cartier-Bresson, nota-se que, para ele, o instante fotográfico do francês possui tempo. E os tempos que mais uma vez se revelam são o presente e o passado daquele homem. O seu futuro está notadamente questionado. $\mathrm{O}$ que tem à sua frente é a sombra da morte que emana do passado remetido pela imagem. O que tem às suas costas é a morte do momento decisivo que o aprisiona no presente eterno.

Um fato importante em relação à imagem mencionada, contudo, é que os tempos aqui referidos se revelam especialmente devido ao discurso de seu espectador, o segundo fotógrafo que desvenda a historicidade da imagem. Disso, surge uma narrativa em que ambas as intenções fotográficas, do fotógrafo-fotógrafo e do espectador-fotógrafo são conjugadas. É interessante, portanto, notar a dinâmica entre o pressionar do obturador pelo fotógrafo e a recepção da imagem pelo espectador, quem irá seguir as direções da imagem

\footnotetext{
${ }^{202}$ Marc Bloch define história como a ciência do homem no tempo. In: Bloch, Marc. "A história, os homens e o tempo". In: Bloch, Marc Apologia da história ou ofício do historiador, Op. Cit.
} 
indicadas pelo olhar do primeiro, mas que também irá trilhar seu próprio caminho através da imagem ${ }^{203}$.

Uma fotografia que se assemelha ao que Rulfo identificara na foto de Cartier-Bresson é Obelisco, 1936, do argentino Horacio Coppola ${ }^{204}$. Com fortes influências da Bauhaus alemã, Coppola voltara suas lentes, em Buenos Aires, para geometrias marcantes da modernidade que se instaurava na metrópole argentina na primeira metade do século XX. Além das fotografias em que as linhas das construções enquadradas por sua câmera apontam, desde o presente, para um futuro promissor, muitas fotografias entornam o tempo a partir de um presente que dilui o futuro, tornando a promessa da modernidade uma expetativa nebulosa. Tal fato se dá nas fotografias de vitrines, manequins e de ruas vazias que tirou em suas andanças pela capital, com aparente forte influência de Atget, quem incursionara pelas ruas da Paris nos primórdios do século XX registrando cenários similares, aparentemente com as mesmas intenções de seu sucessor argentino.

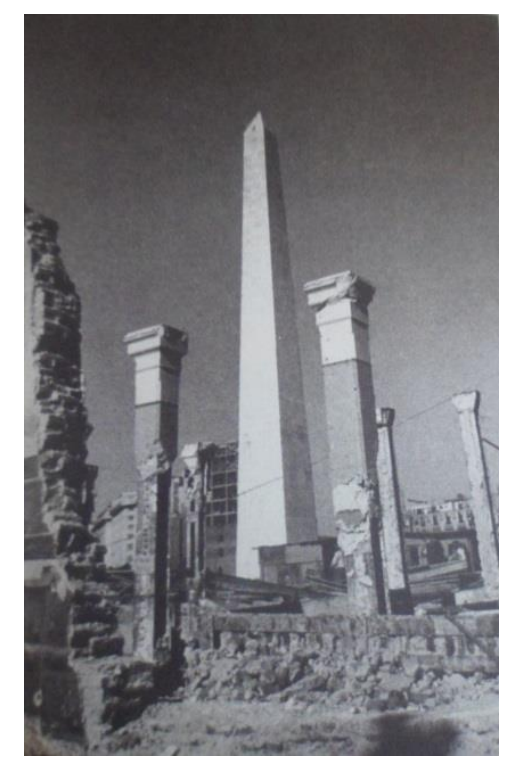

Figura 12 - Horácio Coppola, Obelisco, 1936.

\footnotetext{
${ }^{203}$ É a partir desse caminho que Barthes, por exemplo, encontra o puctum das imagens fotográficas. ${ }^{204}$ Fotografia citada porJorge Schwartz em Schwartz, Jorge. Fervor das vanguardas Ensaios latino-americanas. São Paulo: Companhia das Letras, 2013.
} 
Em Obelisco, Coppola se posiciona atrás das ruínas das colunas de uma edificação demolida e, por entre essas débeis colunas verticais degradadas pelo tempo, focaliza o Obelisco, recentemente construído no cruzamento das ruas Corrientes e Nueve de Julio, em Buenos Aires. O tema da modernidade se faz sobressalente nessa imagem, sendo o Obelisco seu próprio símbolo, numa cidade que seguia artisticamente os ditames das vanguardas europeias e que incorporava a dinâmica de cidade cosmopolita em sua rotina. Além dessa evidente relação com a modernidade, vê-se o contraponto com o novo, com o avant-guarde, feito pelas colunas carcomidas. O próprio Obelisco, que se volta para o futuro, não deixa de lançar um olhar ao passado da cidade uma vez que homenageava sua primeira fundação 400 anos antes de sua construção. Assim como as ruínas das colunas que se dispõem a sua frente, mas que não possuem potência suficiente para subjugá-lo, a construção compõe o conjunto das testemunhas mudas da história de um país que se transformava. O Obelisco, ainda que no segundo plano, revela-se como o verdadeiro centro da foto, proporcionando, também, profundidade na imagem. Os restos de uma muralha, flagrados à sua esquerda, são como uma cortina do tempo passado das ruínas que se abre para o tempo futuro da modernidade simbolizado pela inauguração do Obelisco (um tempo abre espaço para o outro, simbolicamente, mas ambos não deixam de ser simultâneos na imagem).

O próprio Rulfo fotografou uma cena muito semelhante à retratada por Coppola. Ainda que grande parte de suas fotografias tenham sido feitas no interior do país e que tenha um vasto número de fotos de ruínas pré-hispânicas e espanholas, como vem sendo mencionado, Rulfo também se voltou à 
modernidade da capital mexicana. E, como nas outras imagens, a fotografia da modernidade está amplamente embebida de historicidade. A partir da visão do presente da capital, Rulfo consegue remeter o seu passado.

Tal fato ocorre em uma das fotografias recentemente apresentadas na exposição En los ferrocarriles: Juan Rulfo, Fotografías, em cartaz entre maio e junho de 2015 no Centro Cultural Tlatelolco. A exposição reúne as fotografias que fez da malha ferroviária espalhada pelas regiões de Nonoalco, ex-Aduana de Santiago, Tlatilco, Peralvillo, Lerdo,Tacuba e Tlatelolco. Nesta última, filmou-se o documentário de propaganda governamental Terminal del Valle de México (1956) de Roberto Galvadón, mesmo diretor da adaptação de El gallo de oro para o cinema. O documentário tratado contraste entre os trens antigos, atuantes dentro da capital, com os trens modernos, instalados no interior. O objetivo do projeto a que aderiu Rulfo era representar a obsolescência que aquele transporte já começava a apresentar em meados da década de 1950 em decorrência da popularização do carro.

A fotografia de Rulfo mostra vagões da antiga companhia estatal Ferrocariles Nacionales de México (NdeM), bastante novos. Os trens cruzam a imagem desde sua lateral inferior direita até a lateral superior esquerda, dobrando-se como uma serpente e dividindo a imagem em duas partes: esquerda inferior e direita superior. Na parte esquerda inferior da imagem, alguns homens vestidos de terno conversam próximos a uma das portas do trem. Nota-se, também, uma mulher que passa pelos homens, de costas para o fotógrafo, com parte do corpo "decepado" pelo recorte da imagem. Outra mulher, de frente para o fotógrafo, tem apenas a parte esquerda do corpo fotografada, de onde traz, pela mão, uma menina que tem o rosto voltado para 
trás, observando os homens que conversam. A única mulher da que se pode ver o rosto está do outro lado da imagem, na parte direita superior, às portas de uma casa em ruínas. Tem a cabeça levemente abaixada, observando algo que carrega no colo, aparentemente um bebê.

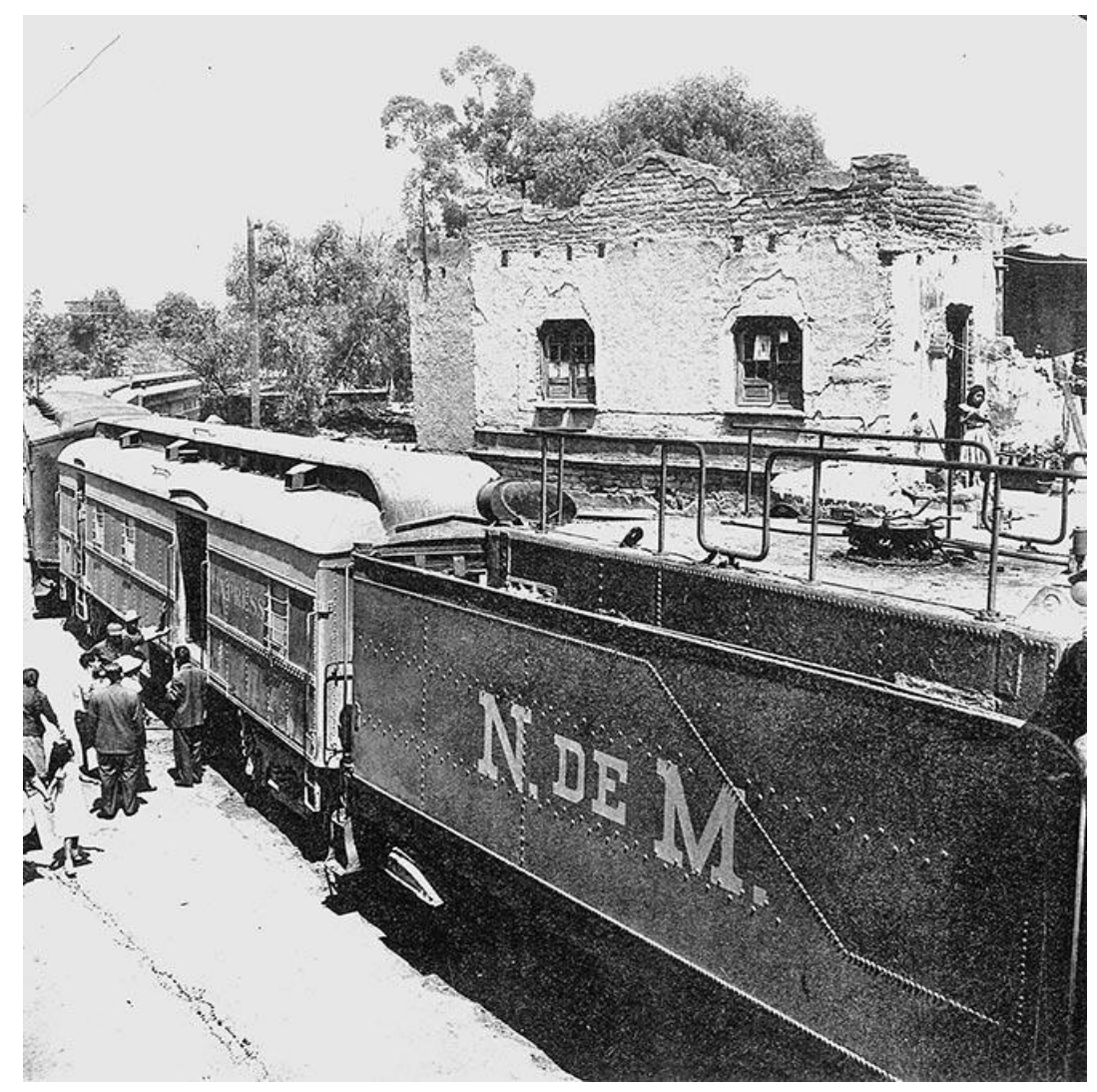

Figura 13 -Juan Rulfo, NdeM, s/d.

A primeira característica que vemos ressoar nessa fotografia é a presença simultânea das ruínas da casa e dos trens da NdeM. A simultaneidade de tempos, mais uma vez, é presentificada com os trens que, num primeiro momento, poderíamos acercar ao futuro da modernidade, e com o passado a que se volta a casa em ruínas. O futuro que o trem poderia sugerir, uma vez contraposto às ruínas da casa que o assiste cruzar a paisagem, contudo, está aniquilado, já que Rulfo registra justamente a "morte" daquela malha 
ferroviária $^{205}$. Sabe-se que a NdeM, ainda que tenha sofrido o impacto da chegada dos carros na década de 1950, deixará totalmente de existir a partir de 1998, quando o então presidente Ernesto Zedillo a privatiza e os serviços para passageiros cessam de vez ${ }^{206}$. O que Rulfo fotografa, portanto, não é a modernidade promissora de Coppola ao fotografar o recém-construído Obelisco, mas, ao enquadrar tanto a ruína da casa onde está a mulher com bebê e os trens parados da NdeM, retrata duas realidades que se voltam ao passado: a primeira, a um passado marcado na construção em decadência da casa, a segunda, a um passado ainda a se inscrever no trem parado. $O$ trem aparentemente se dirigia ao fundo da imagem, caminho oposto ao da criança que o observa no lado esquerdo inferior e também oposto ao que se volta a mulher com o bebê. De fato, na imagem, a única possibilidade de futuro está no caminho dessas crianças que tomam o sentido oposto dos tempos passados ali inscritos na casa em ruínas e no trem parado no tempo.

A imagem das mulheres e da menina, flagradas na fotografia como por casualidade, aproximam, também, a fotografia ao efeito instantâneo de CartierBresson. Em vez de o trem ser aquele que se movimenta na paisagem, são as pessoas ao seu redor que transitam, deixando-o serpentear seu "rastro inerte" na paisagem fotografada, como apontado por Foucault sobre a história contemporânea.

${ }^{205}$ O jornal El País, na ocasião da abertura da exposição En los ferrocarriles..., publicou uma notícia intitulada "Rulfo y la muerte del tren", destacando, justamente, o registro de um passado em construção pelo fotógrafo-escritor a partir da "morte" da malha ferroviária mexicana. Llano, Pablo de. "Rulfo y la muerte del tren”. El País, Cidade do México, 15 de março de 2015. Cultura. Disponível em http://cultura.elpais.com/cultura/2015/03/14/actualidad/1426294310_518651.html>. Acesso em 28/10/2015.

${ }^{206}$ Atualmente, a empresa Kansas City Southern é a responsável por parte dessa malha ferroviária para transporte único de cargas. Em Morelia, capital do estado de Michoacán, a oeste do estado do México, a atuação da empresa estrangeira é motivo de ininterruptos protestos por parte da população local. A extensa malha ferroviária pertencente à multinacional corta a cidade com trens velhos e ruidosos durante todo o dia. 
O que se percebe, portanto, nessa fotografia é uma construção da imagem que busca abarcar não apenas aquele primeiro objeto, a malha ferroviária, mas que tenta retratá-la em relação com outros tempos presentes ao seu redor, relativizando o presente à luz do passado mexicano e, de certa forma, confinando aqueles objetos do presente ao abismo do passado que ecoa na foto. Mais uma vez, uma fenda se abre na imagem a partir das ruínas e do trem parado, demonstrando um passado longo para o qual o espectador deve se voltar.

Essa suspensão do tempo, registrada com o trem parado na imagem acima, demonstra também algo de uma descontinuidade entre as histórias retratadas. Ao referirem-se a dois tempos distintos, casa em ruínas e trem parado, esses objetos marcam a descontinuidade temporal entre si. Desta descontinuidade se constrói, contudo, a história a que se refere a fotografia. A história em Rulfo é a superposição e a presença simultânea de elementos de contextos divergentes. O descompasso cronológico entre um objeto e outro e sua presença simultânea no presente da fotografia constrói uma imagem semelhante àquela da catástrofe única de Walter Benjamin: os distintos acontecimentos se dão de uma vez. O olhar voltado para trás da criança na foto do trem é como o olhar do anjo da história mencionado por Benjamin a partir da pintura do anjo de Klee. A criança é levada para o futuro, pela mão da mãe que a guia, assim como a tempestade que se cola às asas do anjo da história o impulsiona deliberadamente para o sentido oposto daquele da história que vislumbra às suas costas.

Ainda assim, essa visão teleológica da história parece não ser a mais convincente na obra de Rulfo. A história de Rulfo não caminha em direção ao 
seu fim, ela se dobra sobre si mesma, apresenta suas descontinuidades e fragmentos e se revela em sua diferença. Nas fotografias, muitas vezes a apresentação de diferenças do tempo ocorre de maneira quase sublime, como se a imagem gozasse, enfim, de uma paradosis, o tempo eterno cristão.

A fotografia de um chacmool, escultura pré-hispânica utilizada em sacrifícios, tirada em Tula, no estado de Hidalgo, é um exemplo daquela forjada eternidade da imagem de Rulfo. Representando uma figura antropomórfica deitada, com o peito erguido, a cabeça sempre virada, para a direita ou para a esquerda, pernas recolhidas com joelhos dobrados em $90^{\circ}$, os chacmooles têm oferecido um grande desafio aos arqueólogos devido ao mistério que envolve a aparição de várias dessas figuras em diferentes regiões da Mesoamérica.

O chacmool de Juan Rulfo, por sua vez, em vez de causar desconforto e inquietação, traz repouso. A figura é focalizada num ângulo contra-plongée, ou seja, debaixo para cima, sob um céu repleto de nuvens leves que se contrapõem à rigidez da pedra de séculos de história indígena. Tendo a figura pré-hispânica baixo um céu azul do século XX, emoldurada pela modernidade com que o aparto fotográfico impregna a imagem, a fotografia traz à tona o jogo de descontinuidades. A harmonia que a imagem passa, para além do mistério e melancolia que certas ruínas fotografadas por Rulfo possam incitar, fá-la localizar-se fora da linha cronológica que busca situar o monumento na préhistória do continente americano. Diferente do chacmool do conto de mesmo nome de Carlos Fuentes, em que um colecionador se depara com uma figura que se humaniza pelas noites de acordo com o volume de chuvas $^{207}$, o

${ }^{207}$ Publicado no mesmo ano de publicação de El llano em llamas, em Los días enmascarados, o conto "ChacMool", de Carlos Fuentes, narra a história de um colecionador de peças pré-hispânicas 
chacmool de Rulfo não interfere no presente com sua potência do passado. Ele eleva o presente para um tempo outro, em que sua história é sublevada.

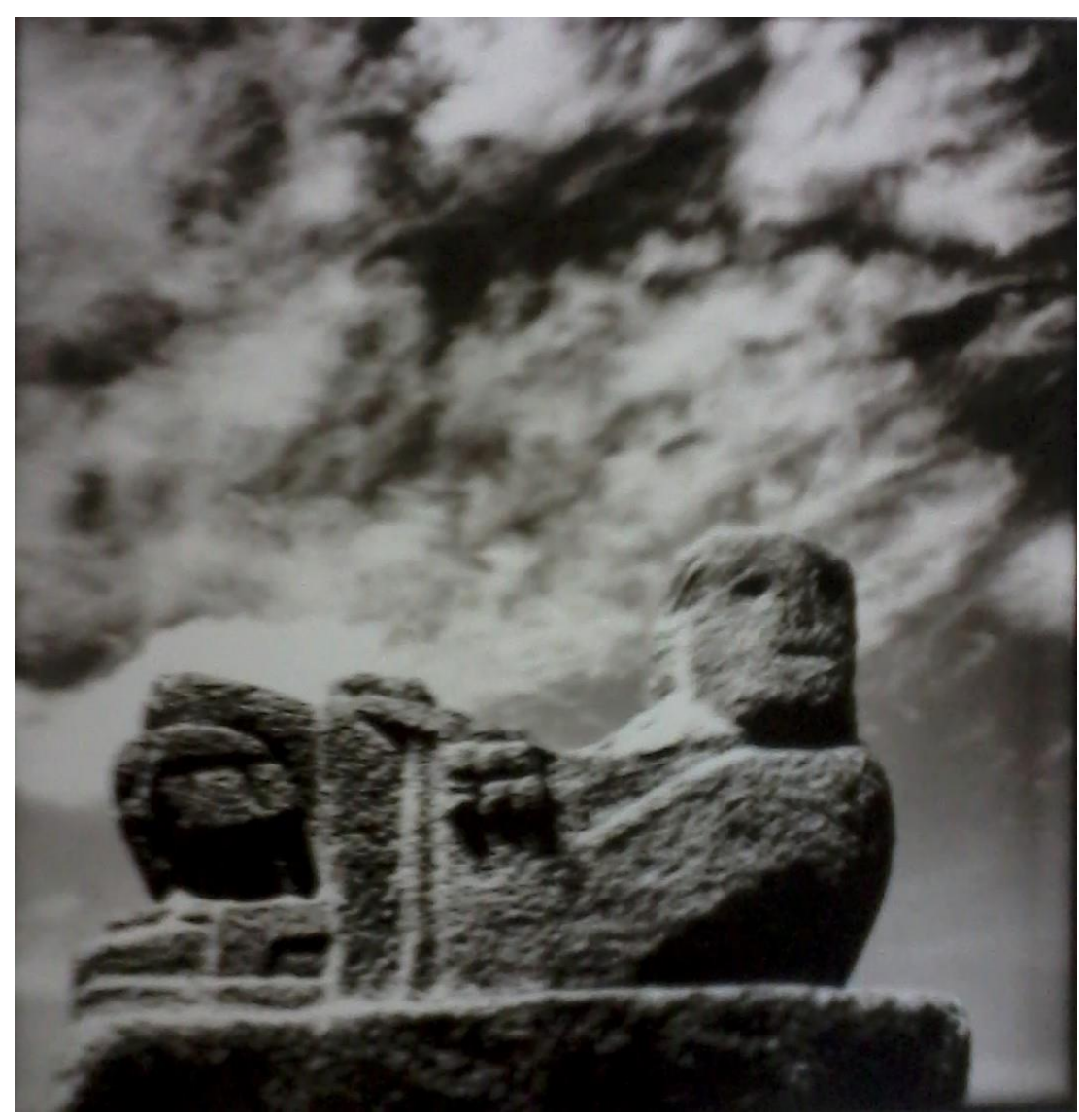

Figura 14 -Juan Rulfo, Chacmool, s/d

São inúmeras as fotografias de Rulfo que podem nos aproximar desse tempo aparentemente fora da história em que passado e presente se encontram de maneira tão intensa. Sabemos, contudo, que as imagens não estão a par dos conflitos que as distintas temporalidades impõem, desde aquela da fabricação do objeto fotográfico até aquela pertencente ao seu observador, como poderia

que acaba por adquirir a peça referida. O colecionador a guarda no sótão de sua casa e percebe que, conforme chove, a figura ganha vida. A figura, no conto de Fuentes, está associada ao deus Tlaloc, deus da chuva asteca. O conto narra, portanto, o encontro entre o passado pré-hispânico e o presente mexicano moderno, representando uma luta entre um em outro, do qual o mundo préhispânico acaba vitorioso, numa catarse revanchista. Fuentes, Carlos, "ChacMool". In: Los días enmascarados. Cidade do México: Ediciones Era, 2006. 
ocorrer se as elevássemos a uma eternidade etérea em que não há temporalidade $^{208}$. Dessa forma, a composição das imagens de Rulfo que, por vezes, faz com que a violência das distintas temporalidades se arrefeça em uma imagem harmônica produz ainda mais complexidade às suas fotografias.

Em uma das fotos que fez da erupção do vulcão de Paticutín que devastara a pequena cidade de San Juan Parangaricutiro, atual San Juan de Angahuan, Rulfo atua nesse mesmo sentido, revelando uma imagem harmônica entre temporalidades distintas e, além disso, focalizando o vulcão de maneira perspicaz, acalmando até mesmo a própria erupção que moveu jornalistas e artistas para o norte do estado de Michoacán em busca de um registro do evento.

No primeiro plano dessa fotografia, vemos uma cruz atrial, sobre uma construção de pedras, posicionada em uma diagonal. O braço esquerdo da cruz aponta para o fundo da imagem, onde, atrás de espécies de cabanas, no plano mais próximo à cruz, ergue-se um cone de fumaça formado no topo de uma montanha que parece pequena e bastante distante desde a perspectiva imposta ao observador. $\mathrm{O}$ cone de fumaça se abre ao céu onde se confunde com nuvens pesadas que avançam até a cruz no primeiro plano. A montanha ao fundo, perceptível apenas por essa fumaça que se contrapõe à rigidez da pedra da cruz atrial é o vulcão Paricutín em erupção.

O posicionamento da cruz atrial do século XVI no primeiro plano demonstra, primeiramente, a importância que o passado tem aos olhos de

\footnotetext{
${ }^{208}$ Sobre essa reminiscência de eternidade, podemos notar que Giorgio Agamben chama atenção para o tempo bíblico da Parousia, momento no qual se mesclam passado e futuro, tempo da "recapitulação" do tempo messiânico, e em que se compõe o presente eterno da segunda vinda de Cristo à Terra. In: Agamben, Giorgio. "The Time that Is Left. "University of Verona.Epoché. Vol. 7, No. 1, Fall 2002. ISSN 1085-1968. pp. 1-14. O que gera a sensação de eternidade, tanto nas fotografias como na narrativa de Rulfo, contudo, é justamente o oposto ao tempo bíblico mencionado: são passado e presente que se mesclam e afastam o futuro das representações rulfianas.
} 
Rulfo. Quando todos se voltam ao evento do presente, as lentes de Rulfo sobrepõem o passado da região ao acontecimento imediato, revelando a problemática escondida atrás do imediatismo da mídia. As lentes de Rulfo, de certa forma, se posicionam no lugar da memória histórica, evitando que ela seja sobreposta pelo evento do presente. A Conquista e a devastação do povoado purépecha são enquadradas na mesma imagem e se relacionam diretamente através da fumaça que as envolve. Esse enquadramento revela o dinamismo histórico do país. O olhar fotográfico de Rulfo vê os restos do passado, representados pela cruz colonial, como vestígios no presente.

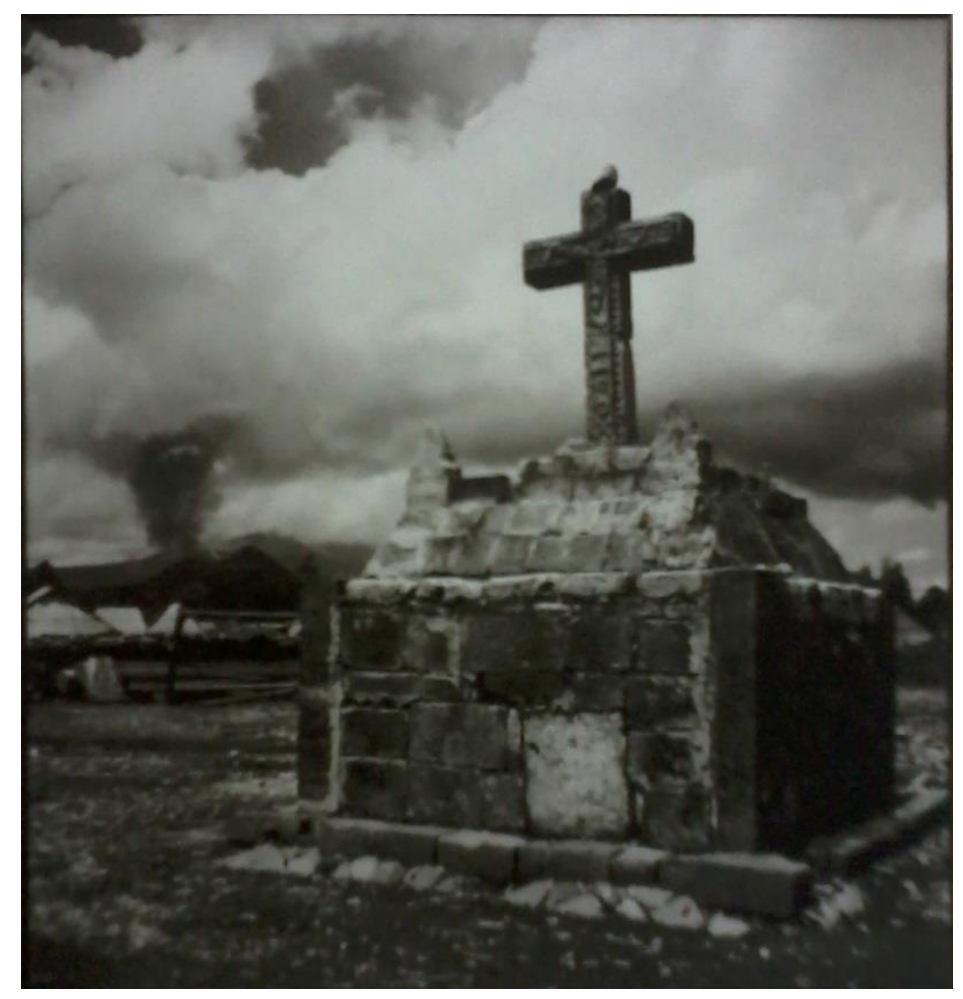

Figura 15 - Juan Rulfo, San Juan de Angahuan, 1943.

Além do hibridismo temporal que compõe a imagem, caracterizando sobremaneira o discurso histórico que é tempo por excelência, a contraposição entre nuvens e pedra, o sólido e o imaterial, é recorrente nas fotografias de 
Rulfo, em especial naquelas que se voltam às ruínas. Essa contraposição dá ênfase à problematização da história que se pode notar na representação construída na foto do vulcão Paricutín. Rulfo não está preocupado apenas em registrar o momento que presencia, mas em problematizá-lo.

A sobreposição que um evento (vulcão) impõe às marcas do outro (Conquista) fornece um registro imagético do que é a história mexicana. Algo do que é mencionado por José Revueltas em sua Crónicas de Paricutín surge nessa abordagem da fotografia de Rulfo, revelando aquela história que havíamos posto em segundo plano ao privilegiar a história vista pelo próprio fotógrafo. Revueltas foi enviado pelo jornal El Popular para a região da erupção para registrar o momento em sua escrita. Escreveu então "[é]ste - se me ocurrió - es México, sombra, luz, desaliento y esperanza; se precipita, como la tierra cuando se acomoda, en formaciones sísmicas, terribles, sangrientas, oscuramente nobles y plenas de dignidad interior". A metáfora da erupção com a identidade do México é possível de ver-se também na construção da imagem fotográfica rulfiana que soma distintos eventos históricos do país em uma única imagem.

É o hibridismo dos tempos da imagem, a contemplação do fotógrafo, o enaltecimento de seus objetos fotográficos, portanto, que vemos nas fotografias de Rulfo. São esses elementos, portanto, que distinguem as fotografias que fez nas excursões pelo interior do México de meras fotografias documentais. A comparação de uma fotografia que retirou no interior do estado de Veracruz frente às ruínas de Castillo de Teayo com uma fotografia de um antropólogo que se dirigiu para a mesma região, anos antes, demonstra com clareza esse olhar de Rulfo que vimos defendendo até aqui. 
O Castillo de Teayofoium centro indígena huasteco "influenciado primero por la cultura tolteca y, en fechas cercanas a la conquista española, por la cultura azteca”, según Raúl Flores Guerrero ${ }^{209}$. Por ese motivo, em 1902 oetno-historiador e antropólogo alemão Eduard Georg Seler viajou até a região para registrá-la em fotografias e produzir o texto "Die Alterthümer von Castillo de Teayo", que apresentou no XIV Congreso Internacional de Americanistas de Stuttgart.

As fotografias que fizeram Rulfo e Seler das ruínas de Castillo de Teayo se asemelham e se diferenciam desde pontos muito tênues. Assemelham-se na busca de conferir importância aos monumentos que retratam, mas, é na fotografia da pirâmide tirada pelos dois viajantes que se nota a diferença entre ume outro.

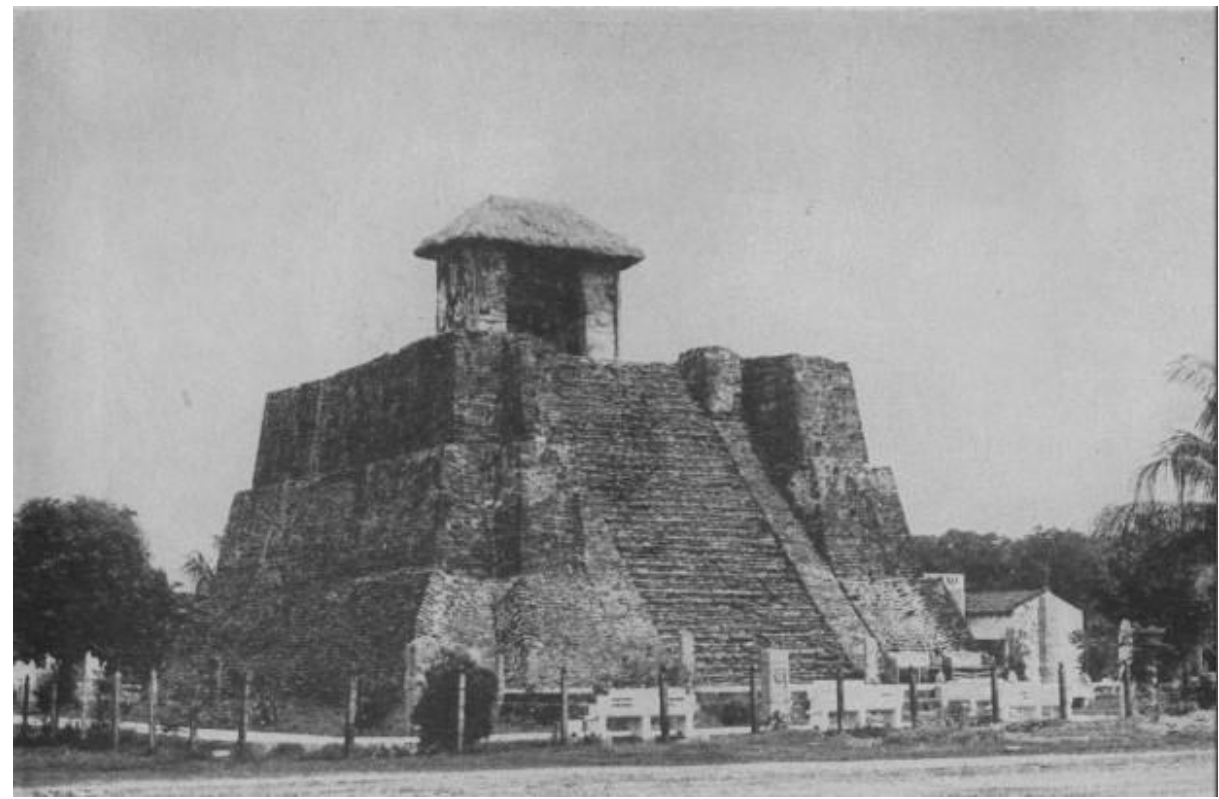

Figura 16 -Eduard Georg Seler, Castillo de Teayo, 1902.

${ }^{209}$ Guerrero, Raúl Flores. "Castillo de Teayo". In: Anales del Instituto de Investigaciones Estéticas, 2015, n. XXXVII. Universidad Nacional Autónoma de México. ISSN 0185-1276 
Ao passo que Seler fotografia a pirâmide de um ângulo normal, ou seja, a pirâmide está enquadrada em frente ao fotógrafo acima da altura dos seus olhos que, a partir de sua imparcialidade, apontam com maior ênfase o carácter documental da imagem. Já Rulfo focaliza o templo em um ângulo ligeiramente contra-plongée, ou seja, se posiciona mais abaixo do monumento enfatizando suas dimensões e grandeza.

Como na maioria das fotografias dos monumentos pré-hispânicos que faz, as pedras da pirâmide se contrapõem com aas nuvens do céu mexicano, marcando a oposição entre o permanente e o efêmero e fazendo com que uma contamine a a outra. As pedras da pirâmide também desfrutando efemeridade, uma vez que são ruinas de um passado irrecuperável. As nuvens do céu também são permanência, uma vez que perduram desde o passado até o presente da fotografia e o presente do seu espectador. Além disso, permanência eefemeridade são conceitos caros à análise historiográfica.

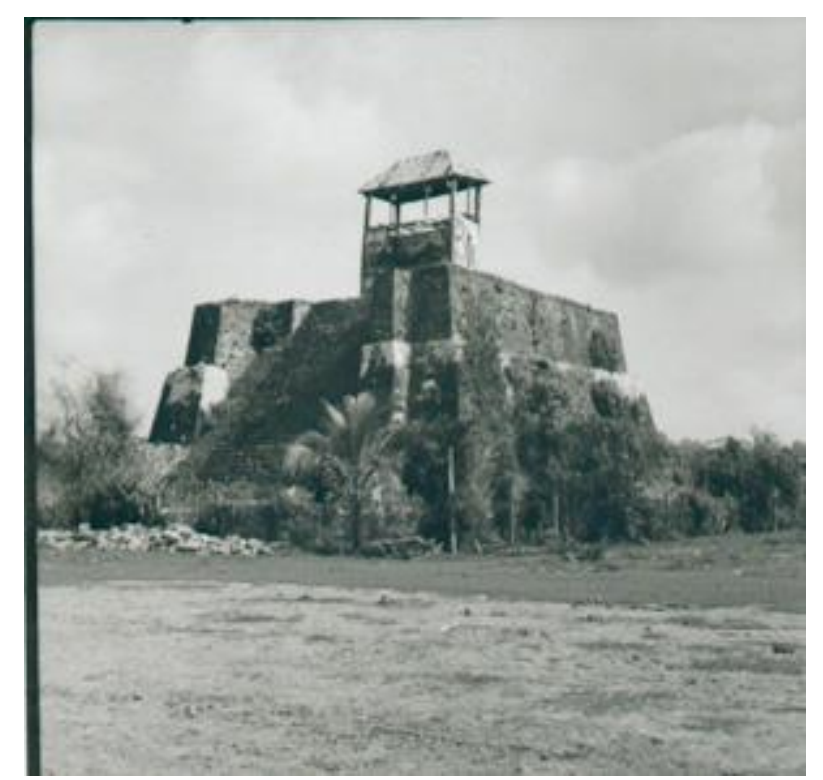

Figura 17 - Juan Rulfo, Castillo de Teayo, 1950. 


\section{A história descontínua em Pedro Páramo}

A viagem a Castillo de Teayo proporcionou um momento único na produção artística do escritor-fotógrafo Juan Rulfo. Acompanhando as fotografias que retirou na ocasião, Rulfo deixou um pequeno conto em que descreve a viagem que realizou. Nesse texto, Rulfo é descrito como um personagem de sua própria escrita. O "Castillo de Teayo" narra uma das tantas viagens que realizara em busca de ruínas para fotografar. Nesta viagem, o escritor ruma para o interior do estado de Veracruz em busca das ruínas do castelo que intitula o texto. O texto pouco se aproxima de um diário de viagem. Rulfo personagem se encontra em uma paisagem de desolação, como aquelas de seus contos e de seu romance, e é alcançado por uma forte chuva enquanto dirige com um amigo para o pequeno povoado onde está o castelo. Em um dado momento da viagem, em meio à noite e à chuva, encontra um habitante da cidadezinha, que poderia ser um dos personagens com quem se encontra Juan Preciado ao perambular por Comala. Como Preciado, Rulfo anuncia ao seu interlocutor que procura por algo estranho, algo que para aquele campesino pouco sentido faz. Afinal, o que aquelas pedras teriam a dizer para alguém que viajava de tão longe?

Em Pedro Páramo, é uma pergunta semelhante que se forma a partir do diálogo entre Juan Preciado e Abundio: o arrieiro, ao guiar Preciado à entrada da cidade, revela com seu falar grosseiro a pouca importância que dá à iniciativa do viajante.

Em "Castillo de Teayo", assim como nas demais obras narrativas de Rulfo, a história pré-hispânica também é referida indiretamente. A grande 
diferença entre este e seus demais escritos em relação a esse tema, contudo, é o título do conto que alude diretamente às ruínas pré-hispânicas. Porém, diferente do que ocorre em "Chacmool” de Carlos Fuentes, as ruínas de Teayo não interferem no presente de maneira tão assertiva como a escultura que ganha vida. Essas ruínas permanecem como ruínas, como os monumentos/testemunhas mudos. Ainda que o ambiente sombrio e chuvoso também se dê no conto rulfiano ("Teayo" significa, em língua mexicana, lugar pedregoso e aquático $)^{210}$ o passado não tem força para se impor aos viajantes. Ou, reformulando, o passado é tão poderoso que sua reminiscência se impõe sem que o discurso possa abarcá-lo diretamente.

A presença da cosmogonia pré-hispânica em Pedro Páramo também surge de maneira oblíqua, mas não por isso deixa de influenciar a história da narrativa. Víctor Jiménez analisou o romance, à luz de seu processo de criação, em relação com os mitos pré-hispânicos ${ }^{211}$. Levando em conta uma carta que Rulfo enviara à sua esposa, Clara Aparicio, em 1947, em que se referia a sua dificuldade em terminar um romance que, oito anos mais tarde, viria a ser Pedro Páramo, Jiménez observa a peculiaridade do título mencionado pelo escritor na ocasião. O romance, naquele momento, chamava-se Una estrella junto a la luna. É este título que faz com que Jiménez se volte para a história pré-hispânica ao analisar Pedro Páramo.

No romance, Juan Preciado, após deambular por Comala, chega à casa de um casal de irmãos incestuosos ${ }^{212}$. Nessa passagem, Preciado observa o céu

\footnotetext{
${ }^{210}$ Guerrero, Raúl Flores. Op. Cit.

${ }^{211}$ Jimenez, Víctor. "Una estrella para lamuerte y para la vida" In: Jeppesen, Anne Marie Ejdesgaard (coord.). Tras los murmullos. Copenhague: Musuem Tusculanum Press. Universidade de Copenhague, 2010.

${ }^{212}$ Este trecho do romance fora citado anteriormente ao nos debruçarmos sobre a questão do tempo no romance de Rulfo e ao analisarmos o momento da morte de Juan Preciado. Conf.
} 
de dentro da casa dos irmãos e se refere pontualmente a uma estrela que se junta à lua nas vezes em que se volta ao alto. No momento em que se percebe morto e que o tempo cronológico lhe escapa, retrocedendo diante da sua vista, Preciado se refere à estrela novamente. Segundo Jiménez, essa estrela faz alusão à Xólotl, uma das representações do deus Quetzalcóatl, principal deus asteca. Na cosmogonia mesoamericana, Xólotl, estrela da tarde, é quem conduz os humanos ao Mictlán, reino dos mortos. A aparição da estrela da tarde no momento da morte de Preciado, portanto, não parece trivial.

Martin Lienhard, por sua vez, fez um trabalho cuidadoso ao destacar a presença da cosmogonia pré-hispânica em Pedro Páramo. Compara, por exemplo, Juan Preciado a Quetzalcóatl, quem, como o personagem do romance, vai ao reino dos mortos, o Mictlán, em busca de seu paie láacaba morrendo. Não obstante, Quetzalcoatl consegue recuperar sua vida, ao passo que Preciado logra apenas narrar sua história dedentro de sua tumba. Lienhard também compara o cacique Pedro Páramo com o deus Tláloc, deus das chuvas e da fertilidade, uma vez que o cacique, ao cruzar os braços frente à cidade, impõe a infertilidade à sua terra.

Por um lado, a cosmogonia pré-hispânica atua de forma bastante presente na narrativa, porém é recuperada somente a partir de uma análise cuidadosa. Por outro lado, a história do México moderno está presente através de referências mais diretas tanto em Pedro Páramo como em El llano en llamas. Como já mencionado anteriormente, Pedro Páramo faz alusão à Guerra Cristera e pode nos levar ao calendário e situar o tempo narrativo em meados dos anos de 1926 a 1929, momento histórico em que a Igreja Católica 
entra em conflito com o Estado, logo após a Revolução Mexicana ${ }^{213}$. Dorotea, a interlocutora de Juan Preciado, é quem introduz esse evento à narrativa, quando conta sobre a decadência de Pedro Páramo: “[y] ya cuando le faltaba poco para morir vinieron las guerras esas de los 'cristeros' y la tropa echó rialada con los pocos hombres que quedaban"214.

O mesmo se dá quando El Tilcuate se refere a carrancistas e obregonistas, oposição política que se dará a partir de 1920, em um diálogo desconexo com os pensamentos de Pedro Páramo que o antecediam:

“El Ticuate siguió viniendo:

- Ahora somos carrancistas.

- Está bien.

- Andamos con mi general Obregón.

- Está bien. ,215

Há duas importantes imprecisões referentes à citação direta deste evento histórico, o confronto entre Álvaro Obregón e Vestusiano Carranza. A primeira se refere ao tempo cronológico evocado por essa passagem. Como exposto no primeiro capítulo de nossa dissertação, a narrativa constrói fragmentos em que o tempo passado e o tempo presente dos personagens se mesclam, como, por exemplo, quando Pedro Páramo e Juan Preciado, em dois momentos distintos, dirigem perguntas às respectivas mães mortas. Portanto, a

213Durante a presidência de Plutarco ElíasCalles (1924-1929), insurge, em vários estados do país, a guerra de Cristo Rey, em que a Igreja Católica se posicionava contra as ações do Estado que tentava laicizar a política e a educação mexicanas. Após várias ações violentas de ambas as partes, incluindo o assassinato por um religioso de Álvaro Obregón, antecessor de Calles na presidência, a guerra é apaziguada em 1929 com o apoio dos Estados Unidos e obtendo a imposição das leis do Estado à Igreja. Respeitadas as leis, porém, a Igreja poderia, agora, agir de forma livre dentro de um Estado finalmente laico. Chávez, Alicia Hernández. Op. Cit., pp. 367-368.

214 Pedro Páramo, p. 86.

${ }^{215}$ Ibidem, p. 124 
menção a um evento histórico cria um nó na hibridez do tempo narrativo que, além de referir-se a simultaneidade dos tempos, se desdobra, também, em um tempo linear evocado pelo tempo histórico.

A segunda imprecisão referida pela citação do confronto se refere à forma como os personagens lidam com o acontecimento. No diálogo entre el Tilcuate e Pedro Páramo percebe-se a falta de lealdade do bando do cacique em relação aos diferentes grupos que se opõem nos primeiros anos da pósRevolução. Reforçada pelo desinteresse do cacique em luto pelo relato que o capanga lhe apresenta, há uma incompreensão do confronto que chega até as imediações da Media Luna, e a adesão do grupo a uma ou outra parte está pautada por interesses particulares que diferem da verdadeira causa do conflito narrado. Os personagens parecem desconhecer a história que lhes rodeia.

Atitude semelhante é percebida em um romance anterior a Pedro Páramo e igualmente de grande notabilidade em sua época: Los de abajo de Mariano Azuela ${ }^{216}$.

O romance de Azuela é considerado uma das obras mais importantes sobre a Revolução Mexicana. Figura ativa da revolução, Azuela descreve a condição da publicação do seu romance: "Villista derrotado, llegué a El Paso, Texas, y en el diario subvencionado por don Venustiano Carranza, El Paso del Norte, se publicó por primera vez mi librito" ${ }^{217}$. Sendo fruto de um autor que vivia a história ativamente, Los de abajo narra avida de Demetrio Macías junto ao seu bando de rebeldes. Fugindo de um cacique, Demetrio acaba se unindo a

\footnotetext{
${ }^{216}$ Azuela, Mariano. Los de Abajo. Barcelona: Ediciones Vicens Vives, 2008.

217 Azuela, Mariano apud Ruffinelli, Jorge. "Los de abajo y sus contemporáneos. Mariano Azuela y los límites del liberalismo". In: Revista Literatura Mexicana. 1990, vol. 1 n. 1. ISSN 0188-2546. Centro de Estudios Literarios. Instituto de Investigaciones Filológicas. Universidad Nacional Autónoma de México, p. 43. Azuela se refere à derrota de Pancho Villa pelas tropas de Álvaro Obregón na Batalha de Celaya em 1915.
} 
um grupo de desarraigados, como ele e, juntos, enfrentam os federales, defensores do governo e contrarrevolucionários. Em uma de suas primeiras investidas contra os federales, Demetrio é ferido e os rebeldes o escondem em um jacal, casa humilde feita de pau a pique e com teto de palha. Enquanto permanecem nesse local, Pancracio e Manteca, membros do grupo, ouvem tiros. Ao sair para verificar o que ocorria, se deparam com um curro, termo usado por eles para se referir a homem letrado. Atiram no pé do homem e o levam como prisioneiro para que trate com seu líder. No encontro entre o homem desconhecido e Demetrio, então, trava-se o seguinte diálogo:

- Por eso, pues, ¿quién jijos de un... es usted? - interrogó

Demetrio.

- Me llamo Luís Cervantes, soy estudiante de Medicina y periodista. Por haber dicho algo en favor de los revolucionarios me persiguieron, me atraparon y fui a dar en un cuartel...

La relación que de su aventura siguió detallando en tono declamatorio causó gran hilaridad a Pancracio y al Manteca.

- Yo he procurado hacerme entender, convencerlos de que soy un verdadero correligionario...

- ¿Corre... qué? - inquirió Demetrio, tendiendo una oreja.

- Correligionario, mi jefe..., es decir, que persigo los mismos ideales y defiendo la misma causa que ustedes defienden.

Demetrio sonrió.

- Pos, ¿cuál la causa que defendemos nosotros?...

Luis Cervantes, desconcertado, no encontro qué contestar ${ }^{218}$.

${ }^{218}$ Azuela, Mariano. Op. Cit., pp. 23-24. 
$\mathrm{Na}$ passagem destacada, o desentendimento entre os personagens, presente também em diálogos de Pedro Páramo, demonstra o desconhecimento das reais causas da luta armada que varria de sangue todo o México de começos do século XX. Demetrio Macías, o herói do romance de Azuela, se junta ao bando guerrilheiro sem que a ideologia trazida pelo homem da cidade fosse seu alento. É, antes de tudo, a sobrevivência que o obriga a seguir na guerra armada. Assim também ocorre com aqueles do outro lado da trincheira e no romance publicado quarenta anos depois. O cacique Pedro Páramo e seu bando, apesar de defensores de suas próprias terras, podem apoiar os revolucionários se isso lhes proporcionar sobrevivência. Porém, justamente no momento da decisão de que lado tomar, Pedro Páramo já está morto. Seguindo a lógica do romance, em que uma morte desencadeia outra, a morte de Susana San Juan impõe a morte do cacique que já não pode decidir, nem lutar, pela sobrevivência das terras que domina e pelo povo que está sujeito a este domínio.

A história da Revolução e da pós-Revolução é, também, a causa da morte e da apatia que toma conta de Comala. A individualidade que caracteriza as ações dos personagens -o padre Rentería que aceita benzer o violador de sua sobrinha por dinheiro, o pai de Susana San Juan que violenta a própria filha, Pedro Páramo que se casa para usufruir dos bens de Dolores Preciado, Dorotea que convence Dolores a se deitar com Pedro Páramo porque queria um filho seu - todas essas atitudes individualistas contrastam com o que o próprio autor disse sobre seu romance. Juan Rulfo afirmara que Pedro Páramo narra a história de um povo. Qual a relação, portanto, que esses atos marcados por interesses privados têm com o coletivo requerido por "povo"? Se tentarmos 
responder essa pergunta tendo em mente a história, e tendo em conta que os sujeitos históricos representados no romance de Rulfo são figuras que agem alheias aos acontecimentos que as rodeiam, podemos inferir que a história acaba levando todo um povo à morte. A história não está morta em Pedro Páramo, a história é a própria morte.

A descida de Juan Preciado à Media Luna, comparada por Lienhard com a descida de Quetzalcoatl ao Mictlán, é também a descida do próprio leitor que tenta desvendar a história por trás do romance à história da morte. Como um trauma, a história é apenas mencionada, não é posta em sua linha cronológica, mas interage com o tempo híbrido do romance, tampouco faz parte consciente da vida do povo que circunscreve. Porém, essa história de morte, ainda que omitida, é impositiva e chega à Comala mesmo sem a plena consciência dos personagens que a vivem.

Os murmúrios que narram e matam tentam reconstruir a história do povo de Comala, mas algo lhes é furtado. Possivelmente, este algo que impede com que os mortos emitam uma voz acabada seja justamente o "núcleo a que concurrieran todas las escenas", como reinvidicado por Alí Chumacero sobre a obra de Rulfo em seu lançamento ${ }^{219}$. O núcleo do romance seria, nesses termos, a história do povo que é a própria morte. O passado em Pedro Páramo é narrado como se estivesse fora de foco, é instantâneo aos murmúrios, rompe a linha cronológica; é um lampejo. A paisagem de Comala é construída através de ruínas de falas, fragmentos, murmúrios, prosopopeias. Juan Preciado visita Comala em busca da história de suas raízes e, com a descoberta da morte de seu pai e de todo o povo da cidade, percebe que a sua própria história nunca

${ }^{219}$ Chumacero, Ali apud Rulfo, Juan. "La primera década: Juan Rulfo, escritor mexicano". In: Rulfo. Juan. Toda la obra. Madri; Paris; Cidade do México; Buenos Aires; São Paulo; Rio de Janeiro: ALLCA XX/Edusp, 1996, p. 586. 
será conhecida. O desmoronamento de Pedro Páramo no final do romance marca a morte da história daqueles que o rodeavam e de seu filho que não teve o retorno à casa concretizado, aos moldes do herói Ulisses.

Rulfo salta da possibilidade de uma trama com um enredo aos moldes clássicos para a história das tumbas enterradas no deserto de Comala. Tumbas estas em que, para Carlos Fuentes em "Las formas que desafían el olvido", se dá o encontro entre o tempo e o espaço. Onde também é reforçada a ideia do orfismo apontada por Octavio Paz em El laberinto de la soledad, em que a história se perde ao tentar rever-se. A história no romance de Rulfo não é linear, pois não tem um ponto de chegada. Seu ponto de partida se dá no início da narrativa, quando Preciado sai de Sayula em busca da cidade fantasma. Mas, uma vez em Comala, a história da morte se impõe e lhe rouba o devenir.

No filme vanguardista La fórmula secreta, filmado dez anos depois da publicação de Pedro Páramo, as tomadas feitas no campo se contrapõem às cenas de uma Cidade do México caótica, em que as relações de trabalho coisificam os homens, e em que a modernidade e o imperialismo norteamericano se confrontam com a desigualdade e as tradições locais. É no momento em que o filme se volta para as imagens dos campesinos filmados em um deserto montanhoso que um poema de Rulfo é recitado em off. Diz o poema: "aquí estamos a medio morir y no tenemos ni siquiera en dónde caernos muertos". A morte que assolava Comala segue assolando o mexicano do campo, ainda quando a modernidade invade o país. Mesmo quando o tempo parece avançar cronologicamente, o paredão da história da morte é erigido, como o paredão de fuzilamento na frente do homem fotografado por CartierBresson. 
Referindo-se notavelmente à Guerra Fria, o filme traz a questão da guerra, os conflitos entre classe dominante e classe operária e o imperialismo norte-americano. As relações de poder, notáveis em Pedro Páramo, estão, aqui, outra vez destacadas. Contudo, diferente do que ocorre no romance, e mais parecido com as fotografias dos símbolos religiosos dotados de dignidade que Rulfo retrata, o filme tem um momento catártico. Ao final, um mariachi, representante do homem do campo, invade a cidade e laça um homem vestido de terno e gravata como se fosse um boi. Entretanto, a catarse também é passageira, pois, logo depois dessa cena, seguem as rodagens no interior de uma igreja barroca, representando, possivelmente, a esperança da redenção messiânica. E, ao terminar o filme, sobem os créditos que, em vez de elencara equipe que participou de sua produção, trazem términos como "Monsanto", “OTAN", "British Petroleum”, "Walt Disney”, "Brigitte Bardot”, “Ku Klux Kan", "Kil Rock was here long time ago", "General Motors", etc., enquanto ouvimos vozes de soldados norte-americanos falando através de seus walktalkies.

O filme se volta para o presente da história do México e para o seu lugar no mundo moderno. Aponta para o depois de Pedro Páramo, o que se passou uma vez que Comala "se llenó de 'adioses" e todos partiram. No romance, não sabemos para onde vão os que abandonam a cidade, mas sabemos que os que ficam estão mortos, como os mortos do campo no filme que rogam por salvação. Esse caminho para o futuro da cidade, contudo, leva a um futuro onde a morte se aloca mais uma vez. Em uma cena em que um operário carrega sacos de cimento, sem se dar conta, carrega também o corpo de outro operário. Nem mesmo na cidade moderna, a morte está ausente. 
A história parece não caminhar, se volta sobre seus próprios pés por causa da imposição da morte, como no trecho já citado em que a mãe de Pedro Páramo assoma na porta do quarto de Pedro menino para contar-lhe que seu pai estava morto. A frase de Walter Benjamin em relação ao anjo da história parece resumir a história nas fotografias e na narrativa rulfiana: "[o]nde nós vemos uma cadeia de acontecimentos, ele vê uma catástrofe única, que acumula incansavelmente ruína sobre ruína e as arremessa aos seus pés. Ele gostaria de deter-se para acordar os mortos e juntar os fragmentos" ${ }^{220}$. O que Rulfo faz é justamente acordar esses mortos e tal atitude faz que a história volte não somente o rosto, mas todo o corpo para o passado impedindo a chegada do futuro: o despertar dos mortos evita que a história avance e transforma a história mesma na morte. A melancolia do anjo da história de Benjamin, que invariavelmente deve deixar com que os mortos e as ruínas se amontoem às suas costas, é necessária para a sua teleologia, para o futuro da história. Diz Benjamin que ao tentar despertar aqueles mortos do passado "uma tempestade sopra do paraíso e prende-se em suas asas com tanta força que o anjo não pode mais fechá-las. Essa tempestade o impele irresistivelmente para o futuro, ao qual ele volta as costas, enquanto o amontoado de ruínas diante dele cresce até o céu. É a essa tempestade que chamamos progresso".

${ }^{220}$ Benjamin, Walter. "Sobre o conceito da história". In: Obras escolhidas I. Magia e técnica, arte e política. Ensaios sobre literatura e história da cultura. São Paulo: Brasiliense, 2012, p. 246. 


\section{Conclusão}

Através da análise dos conceitos de tempo, morte e história na obra fotográfica e narrativa de Rulfo, vemos que estes se relacionam de forma muito clara. O tempo, ao definir-se nas fotografias como híbrido, possibilitando a simultaneidade entre passado e presente, abre as portas para o conceito de morte que, ao adensar esses dois tempos e impossibilitar o futuro do objeto fotografado, atua como a causa daquela hibridização. Sob essa perspectiva, a história, além de ser o estudo do homem no tempo, como pontua Marc Bloch, aponta como o estudo do homem no tempo híbrido entre o presente e o passado. O clique do fotógrafo Juan Rulfo impõe a morte aos seus objetos para os quais volta as lentes de sua câmera e impossibilita o avanço para o futuro nas suas fotografias. Dessa forma, as ruínas, as paisagens, as danças, os músicos, os bastidores de filmes, os trilhos das ferrovias, os detalhes da flora, os indígenas no campo, todos os objetos fotográficos de Rulfo passam a estar enquadrados, também, sob a perspectiva histórica daquele que observa essas imagens.

A relação entre um conceito e outro, portanto, se dá de maneira semelhante às associações entre conceitos apontadas por Kobashi e Francelin $^{221}$ apontadas na introdução deste trabalho. Os autores lembram o rizoma teorizado por Deleuze e Guattari ao referir-se àquelas associações. Essa imagem parece bastante frutífera também para nós ao pensarmos os três conceitos analisados como ramificados em uma árvore de saber cujas raízes são múltiplas. Tempo, morte e história, frutos de ramos distintos, entrecruzamse nas ramificações que os levam a cada uma das obras artísticas de Rulfo.

\footnotetext{
${ }^{221}$ Francelin, Marivaldi Moacir. Kobashi, Nair Yumiko, Op. Cit. Conf. "Introdução”, p. 7.
} 
Na fotografia, os próprios objetos destacados pela câmera contribuem para o deslocamento entre um e outro conceito. As ruínas marcam de forma tácita a presença de passado e presente na imagem. O olhar de Rulfo é quem as coloca sob a perspectiva histórica. Seu trabalho com a câmera é, ao mesmo tempo, aquele de um detetive em busca de vestígios e o de um colecionador que procura por antiguidades. Os vestígios que encontra, como suas imagens o demonstram, não são pegadas deixadas no chão e apagadas pelo vento e poeira e somente reconhecíveis através de técnicas específicas para sua revelação, tampouco são vestígios microscópicos aos quais devem-se voltar lentes de ampliação para poder notar sua presença. Os vestígios de Rulfo são monumentos que, ainda quando em ruínas, impõem sua presença através do enquadramento enaltecedor do fotógrafo que os encontra e os coleciona. É a partir dessa perspectiva que os vestígios-monumentos são dados aos olhos da história.

Desta forma, o deslocamento entre tempo, morte e história nas fotografias do escritor-fotógrafo parece oferecer monumentos que, ainda quando carregam a marca da morte em sua composição, são capazes de revelar uma história possível. A morte se impõe, mesmo que contra a vontade do fotógrafo, às construções e aos personagens que ele buscava impregnar de vida. Porém, essa tentativa de enaltecimento observada pela construção da imagem feita por Rulfo abre as portas para uma história que marca a contraposição entre história pré-hispânica e história moderna, possibilitando um dinamismo à imagem estática e mórbida.

Em Pedro Páramo, contudo, o caminho parece ser mais sombrio. O tempo da história no romance é construído de tal forma que se chega a 
visualizar sua ausência. Apesar disso, a remissão ao passado e ao presente de Comala fornece um dinamismo semelhante àquele referido nas fotografias. Em Pedro Páramo, Rulfo condensa passado e presente nos vários fragmentos que compõem a narrativa e a hibridez desse tempo também se deve à imposição da morte. Desta vez, a morte é a motriz do enredo que atua sobre todos os personagens; ela possibilita o "plot"222 a que se refere Hayden White para a construção da história daquele povo. Uma vez que a morte é a alavanca para o enredo que circunda Comala e para a construção da história da cidade (é o meio através do qual se produzem seus arquivos débeis), e uma vez ainda que a história da Comala ficcional interaciona com a história do México real, percebemos que, no romance, a história tem seu germe na morte. Uma história que nasce da morte é a história da morte. A morte em Pedro Páramo é contagiosa e é capaz de se impor até mesmo à própria história.

A cadeia iniciada pelo caminho do vírus da morte é aquela mesma que possibilita a narrativa histórica de Comala através de Juan Preciado. Os fragmentos são os murmúrios que Preciado escuta e relata à sua interlocutora Dorotea, que o adverte: "[p]ara bien la oreja". Após um fragmento entre aspas em que alguém assume a primeira pessoa e descreve seu contato com o mar, Dorotea irrompe na narrativa, sem aspas, e diz: “[a]hora sí es ella la que habla, Juan Preciado. No se te olvide decirme lo que dice". O discurso indireto é deixado de lado quando da conversa entre Dorotea e Preciado, o que leva a crer que toda a narrativa parte do que ouve Preciado e do que este relata a sua

${ }^{222}$ Segundo White, qualquer história parte de um enredo, "plot", que impõe a "suspensão ou subordinação de alguns elementos e pelo realce de outros, por caracterização, repetição do motivo, variação do tom e do ponto de vista, estratégias descritivas alternativas e assim por diante". Trópicos do discurso: ensaios sobre a crítica da cultura. São Paulo: Edusp, 1994, p. 100. 
companheira de intratumba. Como a morte é contagiosa, o seu discurso também o é: passa dos murmúrios para Preciado, de Preciado para Dorotea, de Dorotea para o leitor, que, ao final de sua leitura também acaba se encontrando com a morte ao deixar o livro. A história da morte só pode ser contada assim, através de sua própria transmissão.

Percebemos, portanto, que aquela pluralidade evocada pelos conceitos aqui elencados e que nos serviram de base para a análise das fotografias e da narrativa rulfianas está presente nas distintas formas como esses conceitos são trabalhados em uma obra e outra. O conceito da história, último a ser analisado, demonstra como que o tempo e a morte na fotografia, ainda quando pareciam serem vistos de forma muito semelhante, se diferenciam do tempo e da morte na narrativa. Os primeiros, por um lado, incorrem em uma história que, apesar de também ter o seu futuro impossibilitado e também ser abatida pela morte, se erige sobre uma base positiva. Os segundos, por outro lado, demonstram como que sua mescla gera uma história enferma que acaba deixando-se morrer, assim como todos os sujeitos que a compõem. A base da história em Pedro Páramo é completamente negativa.

Há uma inversão muito sutil entre as características da fotografia e da escrita na obra de Juan Rulfo. O negativo da fotografia revela uma história positiva. Uma história em que os monumentos indígenas são celebrados no mesmo "tom" enaltecedor que os monumentos espanhóis. A mudez das imagens visuais permite que os negativos revelem essa possibilidade positiva da fotografia. Já o discurso verbal, tão escasso na obra de escritor e na sua própria vida - são recorrentes os relatos sobre o laconismo do escritor- 
fotógrafo $^{223}$ - não deixa lugar a outra coisa que não a morte. A pulsão de morte encontrada por Derrida ${ }^{224}$ nos arquivos submetidos ao poder de uma instituição opressora desponta na narrativa do povo de Comala. O poder do cacique Pedro Páramo é a força opressora que condiciona os murmúrios que chegam com dificuldade a Preciado e com muito mais dificuldade ao próprio leitor. Os arquivos com que o leitor se depara são arquivos repletos do "mal",225 advindo dessas forças de poder, são os arquivos da morte. Antes de esclarecer e iluminar, o discurso verbal obscurece a razão como um negativo de uma imagem que não pode deixar o quarto escuro.

${ }^{223}$ O antropólogo Alfredo López Augustín me relatou a dificuldade que tinha em conseguir travar uma conversa com Rulfo, que estava "siempre callado y en un rincón".

${ }_{222}^{224}$ Derrida, Jacques. Mal do arquivo, uma impressão freudiana. Rio de Janeiro: Dumará, 2005.

${ }^{225}$ Idem. 


\section{Bibliografia}

ANTOLÍN, Francisco. Los espacios en Rulfo. Miami: Ediciones Universal, 1991. ARISTÓTELES. De Anima. São Paulo: Editora 34, 2007.

ARRIGUCCI JR., Davi. “Juan Rulfo: pedra e silêncio” In: Enigma e Comentário. São Paulo: Companhia das Letras, 2001.

ASSIS, Machado de. Papéis velhos. Disponível em <http://www.dominiopublico.gov.br/download/texto/bv000226.pdf>, p. 6. Acesso em 29/09/13

AVELAR, Idelber. Alegorias da derrota: a ficção pós-ditatorial e o trabalho do luto na América Latina. Belo Horizonte: Editora UFMG, 2003.

BARBOSA, Carlos Alberto Sampaio, "Escritura em Chamas - Fotografia de Fogo: Juan Rulfo, escritor e fotógrafo", In: Anais Eletrônicos do VII Encontro $\begin{array}{llll}\text { Internacional } & d a & \text { ANPHLAC. } & \text { Campinas, }\end{array}$ (http://anphlac.org/upload/anais/encontro7/carlos_alberto_s_barbosa.pdf) Último acesso em 18/04/2013.

BACHELARD, Gaston. A Dialética da Duração. São Paulo: Ática, 1988.

BARTHES, Roland. A Câmera Clara: Notas sobre fotografia. Rio de Janeiro: Editora Nova Fronteira, 1984

BENJAMIN, Walter. “A obra de arte na era da reprodutibilidade técnica”. In: Magia e técnica, arte e política. 7. ed. São Paulo: Brasiliense, 1994. 
"Sobre o conceito de história" In: Obras Escolhidas. São

Paulo: Brasiliense, 1996.

BEYCERO, Raúl. La historia de la fotografía en diez imágenes. Buenos Aires: Centro Editor de América Latina, 1980.

BERGSON, Henri. Matéria e Memória. São Paulo: Martins Fontes, 1999.

BLANCHOT, M. Espaço Literário. Trad. Álvaro Cabral. Rio de Janeiro: Rocco, 1987.

BOSI, Alfredo. "Imagem, discurso". In: O ser e o tempo na poesia. São Paulo: Companhia das Letras, 2009.

BOURDIEU, Pierre. As regras da arte. Gênese e estrutura do campo literário. Queluz de Baixo: Editorial Presença, 1996.

BRANDES, Stanley. "Visiones mexicanas de la muerte". In: Martos, Juan Antonio Flores. González, Luisa Abad. Etnografias de la muerte y las culturas en América Latina. Cuenca: Ediciones de la Universidad de Castilla - La Mancha: AECI, 2007.

BUXÓ, Juan Pascual. "Juan Rulfo: los laberintos de la memoria". In: CAMPBELL, Federico (sel.). La ficción de la memoria. Juan Rulfo ante la crítica. México D.F.: Ediciones Era, 2003.

CASTEL, Robert. “Imágenes y fantasmas”. In: Bourdieu, Pierre. La fotografía: un arte intermedio. México D.F.: Editorial Nueva Imagen, 1979. CHÁVEZ, Alicia Hernández. México: una breve historia del mundo indígena al siglo XX. México, D.F.: Fondo de Cultura Económica, 2000 COMTE-SPONVILLE, André. Ser-Tempo. São Paulo: Martins Fontes, 2006. DELEUZE, Gilles. A imagem-tempo. São Paulo: Brasiliense, 2011. 
DEMPSEY, Andrew. "Um estrangeiro em busca de Juan Rulfo". In: 100 Fotografias. São Paulo: Cosac Naif, 2010

DERRIDA, Jacques. "Cap VI. A voz que guarda silêncio". In: $A$ voz $e o$ fenômeno. Introdução ao problema do signo na fenomenologia de Husserl. Lisboa: Edições 70, 1996.

DOVE, Patrick. "Exígele lo nuestro: Transition and restitution in Rulfo's Pedro Páramo. In: Catastrophe of the Modernity: tragedy and nation in Latin American literature. New Jersey: Associated University Presses, 2010.

DUBOIS, Philippe. O ato fotográfico. Campinas/São Paulo: Papirus, 1994

ELIAS, Norbert. Sobre o Tempo. Rio de Janeiro: Zahar, 1998.

ENTLER, Ronaldo. "Retrato de uma face velada: Baudelaire e a fotografia. In.: $\begin{array}{lllllllll}\text { FACOM } & - & n^{\circ} & 17 & - & 1^{\circ} & \text { semestre } & \text { de } & 2007\end{array}$ (http://www.faap.br/revista_faap/revista_facom/facom_17/entler.pdf) Último acesso em 18/04/2013.

FABRIS, Annateresa. “I - A Invenção da Fotografia: Repercurssões Sociais”. In: (org.). Fotografia: usos e funções no século XIX. São Paulo:

Edusp, 1991.

FARES, Gustavo C. “1. El espacio en la obra de Rulfo. A) Referente temporal". In: Imaginar Comala. Nova Iorque: Peter Lang Publishing, 1991 FLUSSER, Vilém. Hacia una Filosofía de la Fotografía. Trad. Eduardo Molina. Edição 1. México, D.F: Editorial Trillas, 1990.

Filosofia da Caixa Preta: ensaios para uma futura filosofia da fotografia. Rio de Janeiro: Relume Dumará, 2002.

FOULCALT, Michel. A arqueologia do saber. Lisboa: Almedina, 2003. 
FUENTES, Carlos. Valiente mundo nuevo - Épica, utopía y mito en la novela hispanoamericana. México: FCE, 1992. . "Las formas que desafían el olvido". In: RULFO, Juan. México: Juan Rulfo, fotógrafo. Barcelona: Lunwerg Editores, 2001. GARCÍA, David. Morir en Comala: mitocrítica de la muerte em la narrativa de Juan Rulfo. México D.F: Ediciones Coyoacán, 2005.

GLANTZ, Margo, "Los ojos de Juan Rulfo". In: RULFO, Juan. México: Juan Rulfo, fotógrafo. Barcelona: Lunwerg Editores, 2001.

HOBSBAWM, Eric. Sobre história. São Paulo: Companhia das Letras, 1998.

JEPPESEN, Anne Marie Ejdesgaard (coord.). Tras los murmullos. Copenhague: Musuem Tusculanum Press. Universidade de Copenhague, 2010.

JIMÉNEZ, Victor. "São apenas imagens”. In: 100 Fotografias. São Paulo: Cosac Naif, 2010. . (org.) Juan Rulfo: letras e imágenes. México D.F.: Editorial RM, 2002.

JIMÉNEZ, Víctor, VITAL, Alberto, ZEPEDA, Jorge. (coord.). Tríptico para Juan Rulfo. México D.F.: Editorial RM, 2006.

KOSSOY, Boris. Fotografia e História. São Paulo: Ática. 1989. Os Tempos da Fotografia. O Efêmero e o Perpétuo. Cotia: Ateliê Editorial, 2007.

LE GOFF, Jacques. História e Memória. Campinas: Unicamp, 1994.

LIMA, Luis Costa. História. Ficção. Literatura. São Paulo: Companhia das Letras, 2066.

LISSOVSKY, Mauricio. “Introdução”. In: A máquina de esperar. Origem e estética da fotografia moderna. Rio de Janeiro: Mauad X, 2008. 
. "Quantos anjos cabem em uma fotografia?". Revista

Icônica [on-line]. 18/06/2013. Disponível em < http://iconica.com.br/blog/?p=5095>.

LUKÁCS, György. O romance histórico. São Paulo: Boitempo, 2011.

MACHADO, Arlindo. A Ilusão Especular. São Paulo: Brasiliense, 1984.

MOCTEZUMA, Eduardo Matos. Muerte a filo de obsidiana: los nahuas frente a la muerte. México D.F: FCE, 2013.

MRAZ, John. "Nacho López y la mexicanidad". In: Revista Lunea Cornea [online]. N. 31: Cidade do México, 2007, p. 165. Disponível em <http://issuu.com/c_imagen/docs/lunacornea_31>.

NATALI, Marcos Piason. A política da nostalgia: um estudo das formas do passado. São Paulo: Nankin, 2006.

NIETZSCHE, Friederich. "Vantagens e desvantagens da história para a vida" In: Escritos Sobre Educação. São Paulo: Loyola, 2003.

PAZ, Octavio. El laberinto de la soledad. Madrid: Cátedra, 2004.

PERALTA, Violeta. BOSCHI, Liliana Befumo. Rulfo, lasoledadcreadora.

Buenos Aires: Fernango García Cambeiro, 1975.

PERUS, Françoise. Juan Rulfo, el arte de narrar. México D. F.: Editorial RM, 2012.

RAMA, Angel. Literatura, cultura, sociedad en América Latina. Montevideo, Uruguay: Ediciones Trilce, 2006.

. Transculturación narrativa en América Latina. Buenos Aires:

Ediciones El Andariego, 2008.

RESENDE PINTO, José Marcelino de. “A teoria da ação comunicativa de Habermas: conceitos básicos e possibilidades de aplicação à administração 
escolar”. In: Revista Paidéia [on-line]. N.8-9: Ribeirão Preto, Faculdade de Filosofia, Ciências e Letras de Ribeirão Preto, 1995. Disponível em<http://www.scielo.br/scielo.php?pid=S0103-

863X1995000100007\&script=sci_arttext $>$ ISSN 0103-863X.

RICOEUR, Paul. Entre tempo e narrativa: concordância/discordância. Trad. João Batista Botton. In: Revista Kriterion. Vol. 53. N. 125. Belo Horizonte, 2012. ISSN 0100-512X. Disponível on-line em <http://dx.doi.org/10.1590/S0100-512X2012000100015>

RULFO, Juan. Oaxaca. México: Fundación Juan Rulfo, Editorial RM, 2009 100 Fotografias. São Paulo: Cosac Naif, 2010. . México. Washington: Smithsonian Institution Press, 2002 . Pedro Páramo. Madri: Cátedra, 2011.

- O Galo de Ouro e outros textos para cinema. Trad. Eric Nepomuceno. Rio de Janeiro: Civilização Brasileira, 1999. . Los cuadernos de Juan Rulfo. México D.F.: Ediciones Era, 1995. Aire de las colinas: cartas a Clara. Buenos Aires: Editorial Sudamericana, 2000. . Los murmullos antes de Pedro Páramo. Tres versiones preliminares y um mecanoscrito. México D.F.: D.R. Instituto Nacional de Bellas Artes, 2005. Toda la obra. Madri; Paris; Cidade do México; Buenos Aires;

São Paulo; Rio de Janeiro: ALLCA XX, 1996

SANTO AGOSTINHO. Confissões, IN-CM, Lisboa, 2001

SONTAG, Susan. Sobre fotografia. São Paulo: Companhia das Letras, 2013

TATARD, Beatrice. Juan Rulfo photographe: esthétique du royaume des âmes. Paris : L' Harmattan, 1994. 
VITAL, Alberto. Rilke, Rulfo. México, D.F.: Samsara Editorial, 2012.

WACHTEL, Nathan. Los vencidos; los indios frente a la conquista española (1530-1570). Madrid: Alianza Editorial, 1976. 